\title{
Handledare och handledning - gymnasial yrkesutbildning på förskola
}

\author{
Åsa Mårtensson
}

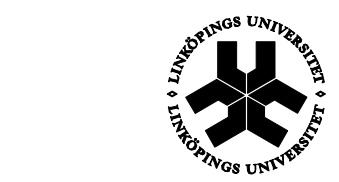

LINÖPINGS UNIVERSITET

\author{
Institutionen för beteendevetenskap och lärande \\ Linköpings universitet \\ LiU-PEK-R-259 \\ Augusti 2014 \\ LINKÖPINGS UNIVERSITET
}


Institutionen för beteendevetenskap och lärande LiU-PEK-R-259

ISBN: 978-91-7519-269-7

Linköpings universitet

Institutionen för beteendevetenskap och lärande SE-581 83 Linköping, Sweden

Tel 013-28 1000

Tryck: Linköpings universitet, LiU-Tryck 2014 


\section{Innehåll}

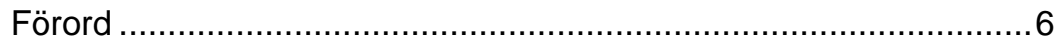

1. Introduktion .......................................................................

Historisk bakgrund till dagens utformning av yrkesutbildning på gymnasieskola ................................................... 9

Gy11 ............................................................... 10

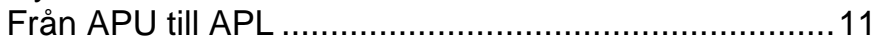

Sammanhanget för studien ............................................ 13

Barn- och fritidsprogrammet .....................................13

APL på Barn- och fritidsprogrammet ..........................14

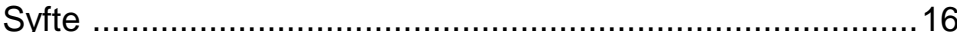

Frågeställningar ................................................. 16

Disposition ........................................................... 16

2. Perspektiv på yrkesutbildning och handledning ........................18

Forskning med fokus på Barn- och fritidsprogrammet ...........18

Yrkesutbildning................................................................ 19

Lärande på arbetsplatsen........................................19

Tillägnandet av yrkesidentitet ...................................20

Deltagande process ...............................................21

Reflektionens betydelse för lärande på arbetsplatsen ..21

Forskning om handledning .................................................22

Handledning generellt ..........................................23

Två modeller för handledning ..................................23

Handledning för yrke ...............................................24

Handledning för yrken inom pedagogisk verksamhet ...25

Handledare i ett europeiskt perspektiv ........................26

Sammanfattning av perspektiv på yrkesutbildning och

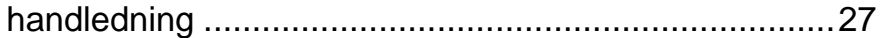

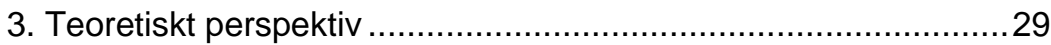

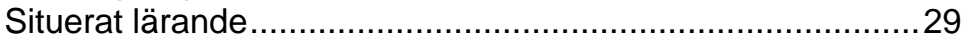

Praktikgemenskaper..............................................29

Legitimt perifert deltagande .................................... 32

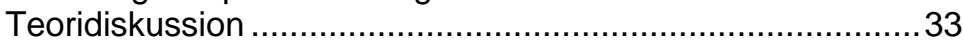

Sammanfattning av teoretiskt perspektiv ............................ 35

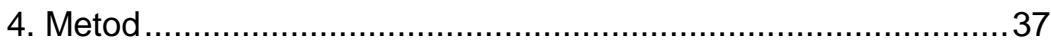

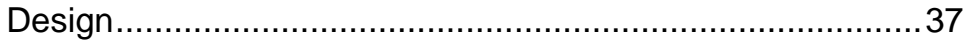

Kvalitativa semistrukturerade intervjuer ......................37

Skapande av intervjuguide ....................................... 37

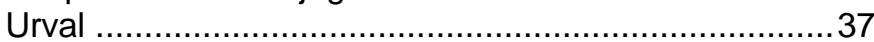

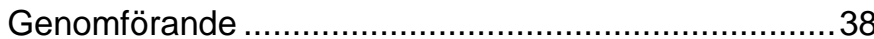

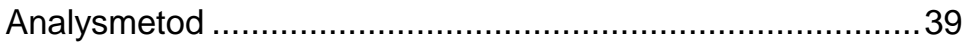


Tematisk analys ................................................... 40

Tillvägagångssätt ............................................... 40

Fallgropar i tematisk analys..................................... 43

Metoddiskussion ........................................................... 43

Etiska ställningstaganden............................................... 44

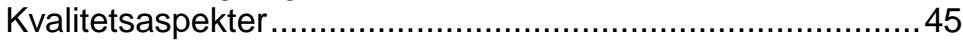

Generaliserbarhet ............................................... 45

5. Resultat........................................................................... 47

Varför handledarna väljer att bli handledare ........................ 49

Det är personligt berikande ....................................... 49

Det ger personlig kunskapsutveckling ........................49

Det leder till eftertanke och reflektion .........................50

Kan påverka nästa generation....................................50

Vad eleverna lär under APL ur handledarnas perspektiv.......53

Vad handledarna vill att eleverna ska lära - Generella arbetslivskunskaper........................................53

Vad handledarna vill att eleverna ska lära - Specifika yrkeskunskaper .............................................54

Det eleverna lär på APL enligt handledarna generella arbetslivskunskaper ...........................57

Det eleverna lär på APL enligt handledarna - specifik yrkeskompetens ............................................. 58

Hur handledning går till ..................................................6 60

Handledning "på tu man hand" ..................................62

Handledning "i farten"................................................63

Vad handledarna talar om att de gör för att stimulera elevernas lärande.............................................65

Sammanfattning av resultaten ......................................... 72

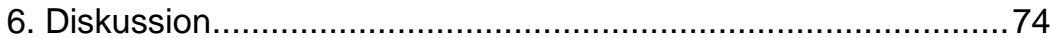

Förskolan som praktikgemenskap.................................. 74

Gymnasieutbildning på förskola .................................75

Lärande genom legitimt perifert deltagande ................76

Hur handledning för yrkesutbildning organiseras och går till.. 77

Organiserad handledning ..........................................78

Oorganiserad handledning .......................................79

Att sätta gränser för yrkeslärande ............................... 80

Finns det ett bästa sätt? ......................................... 80

Handledaren ................................................................. 81

En oldtimer som lär ................................................ 81

Olika sätt att se på och göra handledning ...................83

Vad eleverna lär och inte lär........................................ 85

Varför APL? ................................................................ 86 
Implikationer för gymnasieutbildningen samt förskolan som praktikgemenskap ................................................ 87

Yrkeslärares relationer till arbetsplatsen.....................87

Förskolan som praktikgemenskap.............................88

Utbildningsanordnarnas ansvar för APL ...................... 88

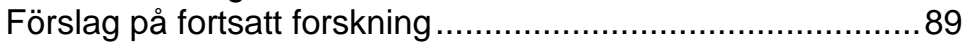

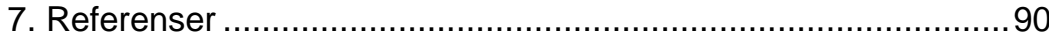




\section{Förord}

Denna licentiatuppsats har kommit till inom ramen för forskarskolan i yrkesämnenas didaktik. Mitt intresse har riktats mot de handledare och den handledning som eleverna på Barn- och fritidsprogrammet erbjuds under den arbetsplatsförlagda delen av sin utbildning.

Att gå i forskarskola kräver många saker. Inte minst hårt arbete, fokus och en kropp som håller för att sitta stilla långa stunder. Det kräver också välvilliga människor runt omkring. Inte minst behöver man bli insläppt i den gemenskap där forskningen blir till. Att få tillträde till denna forskargemenskap känns som ett stort förtroende som jag är skyldig många tack. Till att börja med krävdes det en välvillig huvudman och skolledning samt ett tillåtande sammanhang att vistas i. I detta sammanhang är ni många som är värda tack. Alla kollegor på Anders Ljungstedts gymnasium som med intresserade frågor följt mitt arbete när jag ibland själv har tvivlat, tack! Alla kollegor på Linköpings universitet och IBL som har förklarat, visat och hjälpt mig forma mina tankar kring detta arbete, tack! Alla ni i forskarskolan som emellanåt har varit de enda som egentligen förstått hur livet har sett ut, tack för att ni har funnits där och hoppas att vi ses igen.

Som modeller för hur handledning kan gå till $i$ ett annat sammanhang än det jag har studerat har min huvudhandledare Per Andersson och bihandledare Sofia Nyström kompletterat varandra och alltid haft goda idéer, mycket kunskap och stöttande ord när dalarna har känts djupa och hindren allt för höga för mig, tack! Ett stort tack vill jag även rikta till min familj och mina vänner som har fungerat som en ventil mot verkligheten och aldrig gjort det möjligt att fastna i studierna för länge eller för mycket. $\mathrm{Ni}$ har bidragit mer än ni nog förstår till att denna uppsats blev klar.

Men, utan ni handledare för elever från Barn- och fritidsprogrammet som tog er tid och kraft att svara på mina frågor och så ingående förklara hur ni gör och tänker, utan er hade det inte blivit någonting alls, tack! 


\section{Introduktion}

Hur och var lärde du dig ditt yrke? Vem lärde dig det? Oavsett vilket yrke du arbetar inom idag har du sannolikt mött någon som har introducerat dig och gett dig för yrket viktiga begrepp och kunskaper. Yrkesutbildning har historiskt gått från att ske framförallt på arbetsplatsen till att idag, i många fall, handla om minst 3 års studier på gymnasieskola. Hur väl skolan än kan efterlikna arbetslivet blir det svårt att till fullo förbereda eleverna för vad som väntar på arbetsplatsen efter avslutad utbildning.

Den här studien syftar till att studera och förstå den handledning och den yrkesutbildning som personalen på förskolan erbjuder gymnasieelever inom ramen för Barn- och fritidsprogrammet (BF). Som en del av sin gymnasieutbildning går eleverna på BF, precis som på alla yrkesprogram, ut på en arbetsplatsförlagd del av utbildningen, så kallat arbetsplatsförlagt lärande ( $A P L)$, under minst 15 veckor för att lära yrket tillsammans med redan yrkesverksamma.

Enligt gymnasieförordningen (SFS 2010:2039) ska all utbildning på gymnasiet följa styrdokumenten. En utvärdering av den arbetsplatsförlagda delen av gymnasieutbildningarna år 2010 visade att så inte alltid var fallet (Skolinspektionen, 2011). Utvärderingen fann även stora skillnader i kvalité vad gällde APL mellan både olika skolor och program och även mellan olika program på en och samma skola. Att styrdokumenten ska följas även på arbetsplatsen innebär att yrkesläraren har ansvaret för att utbildningsmålen uppfylls även när eleven är på arbetsplatsen. Handledaren på arbetsplatsen utgör under denna period skolans förlängda arm. Dessa handledares uppdrag eller kvalifikationer skrivs inte fram i styrdokumenten för gymnasieskolan.

Eleverna på BF ska bland annat lära sig bemöta, stödja och assistera människor (Skolverket, 2011). Dessa former av kunskap är svåra att konkret arbeta med i gymnasieskolans klassrum. Den arbetsplatsförlagda delen av utbildningen ger därför mycket viktiga tillfällen att lära och utveckla de kunskaper som annars ofta bara kan samtalas om i klassrummet. På skolan arbetar lärare, ofta med pedagogisk utbildning och erfarenhet, med att möta elever för att uppfylla de nationellt uppsatta målen för utbildningarna. Under den arbetsplatsförlagda delen av utbildningen möter eleverna yrkeskunnig förskolepersonal som i sin roll som handledare även de har som uppgift att stötta eleverna i sitt yrkeslärande.

Mitt intresse för det arbetsplatsförlagda lärandet kommer från mina 16 års erfarenhet som lärare på Barn- och fritidsprogrammet och före det förskollärare. I denna roll har jag både stått som lärare i klassrummet 
tillsammans med elever och sedan mött en del av dem ute på arbetsplatserna tillsammans med deras handledare. Vid dessa möten har det ofta slagit mig hur väl eleverna har blivit mottagna på arbetsplatserna, hur mycket de har lärt sig och vilken enorm tillgång en duktig handledare kan vara för elevernas yrkeslärande.

År 2008 tillsattes Nationella lärlingskommittén med syfte att främja den arbetsplatsförlagda utbildning som bedrevs som försök i form av lärlingsutbildning. I dess slutbetänkande framhåller man att det krävs att universitet och högskolor lägger mer uppmärksamhet på och att mer resurser riktas mot yrkesutbildning inom lärarprogrammen. "Om det arbetsplatsförlagda lärandet nu ska öka i omfattning framöver behövs mer forskning riktad mot hur man lär i arbetslivet, samspelet med handledare och hur yrkeslärarens roll påverkas" (SOU 2011:72 s. 55).

För att ge underlag till ökad kunskap om den arbetsplatsförlagda delen av utbildningen och den verksamhet som de yrkesverksamma ger gymnasieskolans elever tillgång till vill jag med denna avhandling lyfta fram handledarnas insatser samt belysa hur yrkesutbildning sker på arbetsplatsen förskolan.

Eftersom lärandet här har flyttat utanför skolans väggar är det även viktigt att betrakta denna verksamhet ur didaktisk synvinkel. Hur lärandet ska möjliggöras blir en fråga som även handledarna står inför och berörs av. Vid all utbildning är de didaktiska frågorna Varför, Vad och Hur centrala. Varför-frågan kallar Dahlgren (1990) även för legitimitetsfrågan och den besvarar varför ett visst innehåll kommer att finnas med. Vad handlar om undervisningens innehåll och hur handlar om på vilket sätt detta innehåll ska behandlas (Dahlgren, 1990). I detta sammanhang är varför-frågan i grunden besvarad genom de läroplaner som finns, men vad handledarna tar upp behöver inte relatera till läroplanen. Innehållsfrågan vad har gymnasieskolan ansvar för även under APL. Beroende på vad handledaren anser vara viktigt och vad praktikplatsen kan erbjuda för verksamhet kan frågan komma att besvaras olika på olika arbetsplatser. I den här studien blir vad-frågan till vad handledarna vill att eleverna ska lära och vad de anser att eleverna lär. Hur har gymnasieskolan valt att delvis besvara med att innehållet ska behandlas på arbetsplatsen istället för inom skolans väggar och detta kan därför ses som en var-fråga. På detta sätt har nu hur-frågan blivit handledarens fråga istället för som normalt lärarens. Därigenom har handledaren på arbetsplatsen inflytande över elevernas yrkeslärande. 


\section{Historisk bakgrund till dagens utformning av yrkesutbildning på gymnasieskola}

Historiskt sett har det skett stora förändringar i hur yrkesutbildning organiseras. Den dominerande trenden har varit att arbetsplatsen och den erfarne yrkesarbetaren som förr kallades mäster, har ersatts av skolförlagd utbildning. Under den förindustriella perioden lärde individen sig ett yrke genom att gå som lärling hos en mästare. Gränserna mellan praktiskt yrkesutövande och teoretiska kunskaper fanns inte (Nilsson, 1981). Efter skråväsendets avskaffande år 1846 infördes det inte i Sverige, som i resten av Europa, någon lärlingslagstiftning. År 1912 tillkom en grundläggande obligatorisk lärlingsskola för ungdomar mellan 14 och 18 år som var anställda inom industri och hantverk. Dessutom infördes en frivillig fortsättning inom yrkesskola från 17 år där man skulle ha 3 års yrkeserfarenhet för att få tillträde. I denna yrkesskola skulle ungdomarna läsa yrkeskurser och mer allmänna ämnen. År 1918 föreslog regeringen inrättandet av praktiska ungdomsskolor eftersom det ansågs att det inte fanns möjlighet att bedriva yrkesutbildning på arbetsplatserna då specialiseringsgraden var så hög $\mathrm{i}$ industrin. Samma argument, så som allt för hög grad av specialisering $\mathrm{i}$ industrin, att yrkesutbildningarna inte möter dagens krav, att morgondagens arbetare behöver mer teoretiska kunskaper och att omfattningen av yrkesutbildningen behöver öka, har använts gång på gång genom hela 1900-talet för att gradvis förflytta utbildning från arbetsplatsen till skolan (Nilsson, 1981; SOU 2008:27).

På 1960-talet framfördes det krav om att eleverna behövde tränas mer i samarbete, planering och problemlösning i sina framtida yrken. Samtidigt kritiseras även bristen på objektiva bedömningsgrunder i yrkesutbildningen. År 1964 beslutade riksdagen att alla ungdomar skulle få en minst 2-årig utbildning efter grundskolan. Gymnasiet (teorietisk), fackskolan (mer praktisk än gymnasiet) och yrkesskolan (praktisk) samordnades. År 1971 gick de tre samman till en skolform under Läroplan för gymnasieskolan (Lgy70). Yrkesutbildning fanns nu på 13 linjer som i årskurs 2 delades upp mot specifika branschinriktade yrken. En av linjerna var Barn- och ungdomslinjen (som senare kom att byta namn till Barn- och fritidsprogrammet). Svenska var obligatoriskt på alla linjer och det fanns möjlighet att välja till ämnen som matematik och engelska. Utbildningar mot arbeten inom den växande offentliga sektorn var en ny företeelse med reformen. Efter införandet av Lgy70 minskades tiden för yrkesämnena kraftigt och färdigutbildningen skulle ske efter avslutad gymnasieskola på arbetsplatserna under så kallade färdigutbildningsavtal. Sådana avtal kom endast tillstånd inom ett fåtal branscher och en utökning av gymnasiet till 3 år föreslogs därför 1987 (SOU 2008:27). 
Nästa reform inom gymnasieskolan skedde 1994. Läroplan för de frivilliga skolformerna infördes efter krav på mer flexibilitet i yrkesutbildningarna. Efter reformen fanns 16 nationella program, varav två var studieförberedande. Kontakten med branschen skrevs in i form av yrkesråd i läroplansgrupper vid framarbetandet av läroplanen. Dessa yrkesråd kom inte till stånd inom alla program och fick inte den roll som var avsett. Den arbetsplatsförlagda delen av utbildningen (APU) ökade från cirka 6 procent till 15 procent av utbildningen och krav ställdes på en utbildad handledare på arbetsplatsen. APU var avsedd att vara realistisk mot de krav som ställdes efter avslutad utbildning och skulle ha en utslussningseffekt för eleverna. Den ökade andelen tid på arbetsplatsen skulle överbrygga problemet med det glapp som hade funnits mellan den skolförlagda delen av utbildningen och den praktik eleverna gjorde på arbetsplatser (Skolinspektionen, 2011). Ett problem som uppstod i samband med APU var enligt Utbildningsdepartementet (SOU 2008:27) att små företag hade svårt att skicka personal på handledarutbildningar. I och med Lpf94 infördes fler allmänna ämnen på samtliga yrkesutbildningar då de högre utbildningarna ansågs behöva en bredare rekryteringsbas och industrin i högre utsträckning än tidigare krävde goda kunskaper både i allmänna ämnen och i yrkesämnen. APU kunde i sista hand skolförläggas om det inte gick att hitta platser för eleverna på en arbetsplats. Fortfarande skulle yrkesutbildning i gymnasieskolan vara förberedande för yrkeslivet och färdigutbildningen skulle ske i arbetslivet. År 2000 påtalade en parlamentarisk utredning ett ökat behov av generella kunskaper inom industrin och ökningen av allmänna ämnen låg fast. År 2004 ändrades den hållningen i och med propositionen Kunskap och kvalitet - elva steg för utvecklingen av gymnasieskolan. Ökade specialiseringskrav inom industrin skulle mötas med att gymnasiet nu skulle ge eleverna specialsåväl som nyckelkompetenser ${ }^{1}$ (SOU 2008:27).

\section{Gy11}

Hösten 2011 sjösattes den nya skollagen (SFS 2010:800), nya programmål och kursplaner (SFS 2010:2039) för gymnasieskolan som har kommit att gå under namnet Gy11. Anledningen till reformen var att den borgerliga regeringen som tillträdde år 2006 ansåg att det fanns ett antal

\footnotetext{
1 Med nyckelkompetenser avses enligt EU-lagstiftningen en kombination av kunskaper och färdigheter. Exempel på nyckelkompetenser är kunskaper i språk, matematik och teknik, digital kompetens, förmåga att lära, social och medborgerlig kompetens, initiativförmåga och företagaranda samt en kulturell medvetenhet. (Europaparlamentets och rådets rekommendationer om nyckelkompetenser för livslångt lärande, 2006)
} 
problem med den gamla gymnasieskolan (Dir. 2007:8). Bland annat uppmärksammades att andelen elever som inte fått slutbetyg från de yrkesinriktade programmen var stor. Än en gång kom fokus att hamna på de snabba förändringar i arbetslivet som kräver flexibla utbildningar. Detta innebar, skrev regeringen, att utbildningarna behövde anpassas till dessa förändringar. Vidare fanns ett problem i att gymnasieskolan i allt för hög utsträckning varit inriktad på att eleverna skulle gå vidare till högskola och universitet (Dir. 2007:8).

Gy11 innebar en hel del förändringar för gymnasieskolan. Efter reformen finns idag 18 nationella program. 12 av dessa är yrkesprogram och sex högskoleförberedande. Några program tillkom (bl.a. Ekonomiprogrammet, Humanistiska programmet samt VVS- och fastighetsprogrammet), andra försvann (Individuella programmet) och Medieprogrammet blev en inriktning på Samhällsprogrammet.

De högskoleförberedande programmen ska förbereda eleverna för högskolestudier och efter ett yrkesprogram ska eleverna vara väl förberedda för yrkeslivet. Yrkesutbildningen ska hålla hög kvalitet och leda till skicklighet i yrket. Alla elever på ett yrkesprogram ska fortfarande ha möjlighet att uppnå grundläggande högskolebehörighet under gymnasieutbildningen (SFS 2010:800).

\section{Från APU till APL}

Många gymnasieskolor har problem med att tillgodose god kvalité i den arbetsplatsförlagda delen av utbildningen (Skolinspektionen, 2011). Syftet med APU var att arbetslivet skulle påverka innehåll och pedagogik i skolorna vilket inte blev fallet (Skolverket, 2000). Förändringar i arbetslivet skulle innebära ett förvandlingstryck på skolornas etablerade sätt att tänka kring kunskap och lärande och på så sätt skulle arbetslivet påverka pedagogiken i skolorna. Skolverket konstaterar att organiseringen av den arbetsplatsförlagda delen av utbildningarna är en komplicerad utbildningsadministrativ modell. Det förutsätts att det som lärs på arbetsplatsen går att knyta an till läroplanens mål och detta kräver noggrann samplanering mellan skola och arbetsplats (Skolverket, 2000). Problem med APU var enligt Skolinspektionen (2011) att skolorna hade låga ambitioner, att lärarna inte fick tillräckliga resurser för att följa elevernas utveckling under APU, att kursplanerna inte användes under den arbetsplatsförlagda delen av utbildningen och att betyg gavs på oklara grunder. Det framkom även att handledare efterfrågade ett tätare samarbete med skolorna och tydligare instruktioner för vad som förväntades av dem som handledare (Skolinspektionen, 2011).

Den arbetsplatsförlagda delen av utbildningen har lyfts fram genom skärpta skrivningar i och med Gy11. Alla yrkesprogram ska innehålla minst 15 veckors arbetsplatsförlagt lärande (APL). APL ersätter den tidigare 
benämningen APU. Omfattningen är den samma som före 2011, men nu får utbildning endast bedrivas om APL kan erbjudas (SFS 2010:2039). I Lpf94 fanns det skrivningar som antydde att handledaren behövde vara insatt i den arbetsplatsförlagda utbildningens roll i utbildningen. Efter 2011 ska det enligt Gymnasieförordningen (SFS 2010:2039) alltid utses en handledare på arbetsplatsen. Handledarens roll i utbildningen framhålls nu på ett tydligare sätt än tidigare när man skriver att "För en elev som deltar i arbetsplatsförlagt lärande ska det utses en handledare på arbetsplatsen. Som handledare får bara den anlitas som har nödvändiga kunskaper och erfarenheter för uppdraget och som även i övrigt bedöms vara lämplig" (SFS 2010:2039 s. 8).

Handledaren är synlig även i styrdokumentens kunskapskrav som samarbetspartner för eleverna på alla yrkesprogram. Handledaren ska vara elevens samarbetspartner och fungera som ett stöd för eleven att nå upp till de kunskapskrav som Skolverket ställer. På detta sätt återfinns Barn- och fritidsprogrammets handledare som elevens samarbetspartner i vissa kurser när Skolverket definierar vad eleverna ska kunna efter avslutad kurs. Exempelvis står det i kursen "Pedagogiskt arbete" för betyget $E$ att "Eleven planerar, organiserar och utför i samråd med handledare vanligt förekommande enkla arbetsuppgifter och aktiviteter på ett yrkesmässigt sätt" (Skolverket, 2014a).

År 2012 gick drygt 35 procent av alla Sveriges gymnasieelever ett yrkesprogram (Skolverket, 2013). Under APL har eleverna tillgång till en realistisk miljö, modern utrustning och de resurser som en yrkesskicklig handledare kan erbjuda. Gymnasieförordningen lämnar det relativt fritt för varje skola att organisera det arbetsplatsförlagda lärandet som det passar skolan och respektive bransch. Det är huvudmannens ansvar att skaffa praktikplatser till eleverna. Det är rektor som beslutar om hela eller delar av kurser ska förläggas till arbetsplatser och hur fördelningen av dessa perioder ska se ut. En vecka som eleven befinner sig på en arbetsplats ska räknas som 23 timmar undervisningstid. På många skolor delegerar rektor uppgiften att besluta om APL till programarbetslag eller enskilda lärare (SFS 2010:800).

Friheten i organisering av utbildning och APL leder till att det kan se väldigt olika ut mellan kommuner, skolor och program. Där vissa program har eleverna ute på APL en eller två dagar i veckan regelbundet under långa perioder har eleverna på andra program arbetsplatsförlagd tid hela veckor utspridda under tre år. Det är inte ovanligt att den praktikförlagda delen av utbildning ökar mot den senare delen av utbildningen. Vad eleverna ska lära på APL är också upp till varje skola att fatta beslut om. Ett sätt för skolan att styra innehållet i praktiken är att eleverna får med sig arbetsuppgifter att genomföra under praktikperioden. Dessa 
arbetsuppgifter kan utformas som att ta reda på fakta om arbetsplatsen eller som specifika uppgifter eleverna ska genomföra (SFS 2010:2039).

Vid Skolinspektionens utvärdering framkommer att ett av de program som klarar sig bäst vid alla utvärderingar av praktikförlagd utbildning är Barn- och fritidsprogrammet (Skolinspektionen, 2011).

\section{Sammanhanget för studien}

I följande avsnitt beskrivs det sammanhang där studien är utförd. Handledarna som är i fokus arbetar på förskolan och ska där ta emot elever från Barn- och fritidsprogrammet. Yrkeslärande genom handledning blir centralt eftersom det traditionellt är ett dominerade sätt att utbilda för verksamheten. Vid traditionell skolforskning riktas fokus mot elever eller lärare men här kommer fokus att riktas mot arbetsplatsen och de handledare som tar emot eleverna under den arbetsplatsförlagda tiden av utbildningen.

\section{Barn- och fritidsprogrammet}

Barn- och fritidsprogrammet tillkom som ett svar på den offentliga sektorns behov av kompetent personal inom barn-, ungdom och även fritidssektorn. Programmet uppstod ur en sammanslagning mellan framförallt Vårdlinjens Barn- och ungdomsgren men även specialkursen för bad- och idrottshallspersonal och vissa delar av gamla Sociala linjen (Skolverket, 1997).

BF är ett yrkesprogram där eleven efter examen ska ha de kunskaper som behövs för att arbeta med barn, ungdomar och vuxna inom pedagogiska och sociala yrkesområden eller i fritids- och friskvårdssektorn. Viktiga kunskapsområden är att kunna möta, assistera och stödja människor. Vidare framhålls förmågor som att vara lyhörd, kreativ och att med omdöme kunna skapa optimala förutsättningar för alla människors delaktighet och lärande (Skolverket, 2011).

BF har tre inriktningar: Fritid och hälsa, Pedagogiskt arbete och Socialt arbete. Exempel på yrkesutgångar inom Fritid och hälsa är bad- och sporthallspersonal och personlig tränare. Inriktningen Pedagogiskt arbete har yrkesutgångar som till exempel barnskötare och elevassistent. Efter att ha gått inriktningen Socialt arbete kan eleven arbeta som väktare, personlig assistent eller som stöd- och serviceperson inom funktionshinderområdet. Gemensamt för alla inriktningarna är att de förbereder för arbeten där människan står i centrum. Som för alla yrkesprogram ska APL förekomma under minst 15 veckor. All APL ska vara riktad mot tänkt yrkesutgång (Skolverket, 2012). År 2013 började ungefär 3100 elever på BF och av dem var knappt två tredjedelar flickor. Sammanlagt gick det samma år cirka 9400 elever på programmet (3 
årskullar) varav 2000 på inriktningen Pedagogiskt arbete (Skolverket, 2014b).

\section{APL på Barn- och fritidsprogrammet}

Som tidigare beskrivits är det fritt upp till varje huvudman att organisera utbildningarna som det passar den lokala skolan och branschen. Den beskrivning som görs här kommer ur egen erfarenhet och kontakter med gymnasieskolor sedan 15 år. Den stämmer bra överens med den sammanställning som Skolinspektionen gjorde år 2011 för hur skolorna klarar att uppfylla målen för APU (Skolinspektionen, 2011; se även Lemar, 2001). Ett typiskt upplägg av den arbetsplatsförlagda delen av utbildningen på Barn- och fritidsprogrammet är att eleverna i årskurs 1 är ute på en kortare APL för att bekanta sig med vald utbildning. I årskurs 2 sker APL inom vald inriktning för att $\mathrm{i}$ årskurs 3 avsluta med en längre period APL. Den arbetsplatsförlagda delen av utbildningen kan förläggas alla dagar i veckan men kan också förekomma under enstaka dagar under flera veckor beroende på vad som passar verksamheten där APL är förlagd och hur skolor har valt att organisera läsning av gymnasiegemensamma ämnen. Vissa kurser kan vara praktikförlagda upp till 90 procent av kurstiden medan andra läses till större del i skolan. APL på förskola förekommer ofta under hela veckor och under längre perioder.

De arbetsplatser som tar emot en elev på APL får innan eleverna börjar information om elevens namn, vem som är ansvarig för kursen, kursmål och annan praktisk information. Den person som är utsedd att handleda eleven får ofta en inbjudan till en kortare handledarutbildning. Tillsammans med handledare på arbetsplatserna ska alltså lärarna i gymnasieskolan utveckla de beskrivna kunskaperna hos eleverna.

Trots att BF är ett av de program som i Skolverkets och Skolinspektionens utvärderingar får bäst kritik anser jag att det finns anledning att belysa den arbetsplatsförlagda delen av utbildningen. På BF utbildas (bland annat) barnskötare som ska lära sig att bemöta barn. Denna utbildning äger i mycket stor utsträckning rum i ett klassrum där det är mycket svårt att efterlikna en realistisk miljö. För att lära de så viktiga yrkeskunskaperna går eleverna ut på arbetsplatsförlagt lärande under 15 veckor. De yrkesverksamma som då fungerar som handledare blir då viktiga för eleven och utbildningen.

\section{Handledare i förskolan och deras yrkeskunnande}

I förskolan arbetar två yrkesgrupper, förskollärare och barnskötare, som har olika utbildningar och lön. De flesta barnskötare har en minst 2-årig gymnasieutbildning (BF) eller en kortare gymnasial påbyggnadsutbildning. Förskollärarna har minst 2 års högskoleutbildning. Både barnskötare och 
förskollärare kan fungera som handledare för elever från BF. Förskollärarna kan handleda studenter från förskollärarutbildning men det kan inte barnskötarna.

I den här studien är fokus på att förstå hur handledarna organiserar och bedriver den handledning som kommer ge eleverna tillgång till kårens yrkeskunnande under den arbetsplatsförlagda delen av barnskötarnas yrkesutbildning. Yrkeskunnande, kompetens och kvalifikation måste alltid relateras till en uppgift (Ellström, 1992). Yrkeskunnande är i det här sammanhanget de kunskaper och färdigheter som en individ behöver för att klara av arbetet på förskola. I detta yrkeskunnande ingår både motoriska färdigheter, attityder, kunskaper och metakognitiva färdigheter. Kunskaper kan vara av både explicit och implicit form. De explicita kunskaperna är de som kan verbaliseras medan de implicita är kunskaper som (ännu) inte kan formuleras i språklig form. Ellström skiljer även på formella kvalifikationer och de faktiska krav som finns på arbetsplatsen (Ellström, 1992). För att bli anställd som förskollärare krävs idag förskollärarlegitimation medan det för barnskötaranställning inte finns några formella krav.

Förskolans verksamhet styrs av Läroplan för förskolan (Lpfö 98/10) som reviderades år 2010 (Skolverket, 1998/2010). Förskolans uppdrag är att lägga grunden för ett livslångt lärande. Förskolan ska vara rolig, trygg och lärorik för alla barn som deltar samt erbjuda trygg omsorg. Lpfö 98/10 betonar personalens förmåga att genom samspel med barnen få även föräldrarnas förtroende så att förskolan blir en positiv upplevelse för alla barn. De ska få erfara att göra framsteg och att vara en tillgång i gruppen. Verksamheten i förskolan ska förutom att vara trygg även utmana och locka till lek och aktivitet. Barnen ska få möjlighet att iaktta och reflektera och miljön på förskolan ska vara kulturellt levande och stimulerande. Barnens lärande ska stimuleras vilket förutsätter en aktiv diskussion i arbetslaget kring begrepp som kunskap och lärande (Skolverket, 1998/2010). Hur läroplanens mål ska uppnås är upp till varje arbetslag att bestämma. Vad som ingår i barnskötarens och förskollärarens yrkeskompetens definieras av läroplanen. Förskollärarens roll står tydligt uttryckt som ansvarig för verksamheten medan barnskötaren ingår $\mathrm{i}$ gruppen arbetslaget. Vad dessa skillnader i handledarnas olika positioner i förskolan innebär för deras arbete som handledare fanns det inte möjlighet att ta hänsyn till vid denna studie men skulle vara ett intressant område för vidare studier. Förskolepersonalens yrkeskunnande kan vid en läsning av Lpfö 98/10 kortfattat uttryckas som att de ska kunna arrangera rolig verksamhet där det finns möjlighet för alla barn att utvecklas och lära.

Personalens yrkeskompetens är oklart definierad och utan klara regler och därför finns ett stort handlingsutrymme för arbetsgrupperna att 
utforma verksamheten och ett gemensamt arbetssätt (Ohlsson, 1996). Läroplanen för förskolan skriver fram ett vad som ska göras men inte hur detta ska göras. Arbetet i förskolan beskrivs som relationsinriktat vilket betyder att personalen arbetar i nära relation till barnen och övriga $i$ personalgruppen. Personalens kompetens beskrivs som individuell snarare än kollektiv då personligheten och de egna värderingarna är framträdande $i$ arbetet med barnen. Kompetensen beskrivs vidare som tyst och erfarenhetsutvecklad snarare än inlärd vid formell utbildning. Förskollärare uttrycker själva att deras yrkeskunnande bland annat handlar om att få barnen att känna sig trygga (Ekström, 2007).

Med en bakgrund där en viktig del i yrkesutbildningen till barnskötare sker på arbetsplatsen och att handledaren där är en central person för elevernas yrkeslärande menar jag att det finns ett behov av att vidare studera den handledning som eleverna möter som en del av det arbetsplats förlagda lärandet på Barn- och fritidsprogrammet.

\section{Syfte}

Syftet med den här studien är att förstå handledning och yrkeslärande på förskola ur handledarnas perspektiv. Studien avser att identifiera hur förskolans "old-timers" - handledarna - beskriver att de ger gymnasieeleverna möjlighet att komma in i praktikgemenskapen. Detta innefattar såväl motiven för att handleda, och hur handledningen görs, som vad handledning och deltagande i förskolans arbetspraktik leder till för gymnasieeleverna. Närmare bestämt fokuserar studien på följande frågeställningar:

\section{Frågeställningar}

Vilka motiv uppger handledare ligger bakom deras engagemang?

Vilka kunskaper anser handledarna att eleverna borde lära sig och lär sig genom sitt deltagande arbetspraktiken?

Vad gör handledarna för att eleverna ska komma in i praktikgemenskapen på förskolan?

\section{Disposition}

Den aktuella studien tar avstamp i ett sociokulturellt perspektiv på lärande vilket innebär att mänskliga handlingar ska förstås i en historisk och social kontext (Säljö, 2000). För den här avhandlingen innebär det att den inleds med en beskrivning av yrkesutbildning i ett historiskt sammanhang och framförallt hur yrkesutbildning flyttade från arbetsplatsen till skolan.

I kapitel 2 beskrivs tidigare forskning kring Barn- och fritidsprogrammet och hur yrkesutbildning traditionellt har gått till. Vidare beskrivs och diskuteras olika modeller för lärande på arbetsplatsen och framför allt 
handledning. I kapitel 3 beskrivs studiens teoretiska ramverk och i kapitel 4 den metod, med datainsamling genom intervjuer som har använts för att uppnå syftet med studien. Resultatet av intervjuerna redovisas i kapitel 5 och i det sista kapitlet diskuteras studiens resultat i förhållande till teori och tidigare forskning. 


\section{Perspektiv på yrkesutbildning och handledning}

I det här kapitlet ges en översiktlig bild av olika perspektiv på och tidigare forskning om utbildning för förskolan, lärande på arbetsplatsen och handledning. Handledning kommer inledningsvis att beskrivas generellt, sedan för yrkeslärande och med visst fokus på handledning för yrken inom pedagogisk verksamhet.

\section{Forskning med fokus på Barn- och fritidsprogrammet}

Gymnasieskolans Barn- och fritidsprogram har sällan varit det huvudsakliga fokuset för någon studie. Det finns dock tidigare forskning om lärarna som undervisar där (Lemar, 2001) och om elevernas identitetsskapande (Ambjörnsson, 2004).

Lärarna på BF uppfattar elevgruppen som en heterogen grupp ungdomar med stora skolsvårigheter och lärargruppen beskrivs som homogen. Eleverna påverkar lärarna till att utveckla ett förhållningssätt och arbetsmetoder som svarar mot dessa behov. Innehållet i programmet beskrivs enligt lärarna som personlighetsutvecklande och tillsammans med ett individanpassat förhållningssätt bestämmer det lärarnas handlingsmönster. Lärarna på BF är inte alltid utbildade för att undervisa i de kurser som finns inom programmets ramar (Lemar, 2001).

En annan aspekt som har belysts är hur flickor på BF och Samhällsprogrammet (SP) skapar genus i relation till klass och sexualitet. Flickorna på BF var mer utåtagerande och kunde tänja mer på gränserna för det accepterade än flickorna på SP. Flickorna på SP hade med sannolikhet högre status men samtidigt en snävare ram för hur de skulle bete sig som kvinna (Ambjörnsson, 2004).

Forskning om utbildning för arbete inom förskolan har dominerats av studier om förskollärarutbildningen (se exempelvis Folke-Fichtelius, 2008; Tallberg Broman, 1991; 1995). Förskolläraryrket var ett av de första som gjordes tillgängligt för kvinnor och yrket beskrevs som exklusivt lämpat för kvinnor. Utbildningarna konstruerades av kvinnor, för kvinnor och skulle leda till att förskolläraren inte bara skulle kunna något bestämt utan utbildningen skulle även förändra henne och ge henne en stark yrkesidentitet (Tallberg Broman, 1991). Fortfarande är anpassning till den rådande normen ett starkt inslag $\mathrm{i}$ utbildningen till förskollärare. Detta kontrollerar handledarna och lärarna genom de reflektionssamtal som 
ingår som en del i utbildningens arbetsplatsförlagda del (Sundli \& Söndenå, 2007).

\section{Yrkesutbildning}

Som tidigare beskrivits har yrkesutbildning historiskt skett på arbetsplatsen i större utsträckning än vad som är fallet i dag. Den forskning som berör yrkesutbildning går även under benämningar som till exempel arbetsplatslärande och yrkeslärande. Den tidigare forskningen kring lärande på arbetsplatsen är omfattande (se exempelvis Ellström \& Hultman, 2004; Höghielm, 2005; Kvale, 1999). I stor utsträckning fokuserar den på hur den anställda personalen lär sig och utvecklas på arbetsplatsen.

\section{Lärande på arbetsplatsen}

Studier med fokus på lärande på arbetsplatsen är det ofta de individer som är satta att lära som är av intresse. Om fokus enbart riktas mot de som lär hamnar mentorer/handledare i skymundan. Forskning om arbetsplatslärande visar bland annat att lärande på arbetsplatsen kan delas upp i två ytterligheter, reproduktivt lärande och utvecklingsinriktat lärande (Ellström, 1992; Fuller \& Unwin, 2004). Den förstnämnda innebär att kunskap förvärvas i form av givna kunskaper, begrepp och metoder. Redan etablerad kunskap lärs vidare. Vid den senare formen är synen på lärande att det är ett ifrågasättande av givna föreställningar, kunskaper och materiella förutsättningar. Fokus ligger här på en ömsesidig utveckling hos både individen och verksamheten. Enligt en socialkonstruktivistisk tradition kan detta lärande ses som att omgivningen begränsar och möjliggör den lärandes handlande och samspel med andra. Omgivningen återskapas och förändras som ett resultat av detta lärande (Ellström, 1992; Ellström \& Hultman, 2004).

Fuller och Unwins studier (2004) på många olika arbetsplatser visar att olika arbetsplatser inom samma bransch kan uppvisa olika möjligheter till lärande. De faktorer som bidrar till utveckling av arbetskraften och skapande av goda lärandemiljöer benämns som expansiva och skapar god grund för lärande jämfört med en restriktiv miljö. En expansiv miljö kännetecknas av att den inkluderar alla deltagare i beslutsfattande dialoger. Vidare respekterar man, tar tillvara och värdesätter de anställdas och nykomlingars kompetens. Man uppvisar tilltro till att deltagarna har omdöme att fatta beslut och visar att de har ledningens förtroende. I en expansiv lärmiljö ges stöd för hur arbetet ska utföras och konstruktiv feedback på utfört arbete, man underlättar utbyte av kunskap inom hela organisationen och det finns en stolthet över de produkter och tjänster som produceras. En nyckelfaktor för att underhålla ett hållbart lärande är bland 
annat att bygga in stöd från chefer till de som befinner sig nära lärmiljöerna (Fuller \& Unwin, 2004).

Med sociokulturellt perspektiv flyttas lärandefokus från individen till den process som pågår i en specifik situation och det lärande som därigenom uppstår. Om forskning om yrkeslärande bortser från handledaren åsidosätts en del av helheten eftersom hur handledaren uppfattar situationen kommer att påverka elevernas lärande. Faktorer som leder till att handledare upplever att de fungerade bättre som handledare är att de får utbildning i att vara handledare, har stöttande kollegor, får erfarenhet av rollen och därigenom förstår elevernas behov. Faktorer som sågs som hämmande var höga produktionskrav, ojämn arbetsbelastning, brist på tid och elevernas attityd. Brist på tid för att fylla rollen som handledare var den oftast rapporterade svårigheten (Billett, 2003).

\section{Tillägnandet av yrkesidentitet}

Att lära från en mästare är en gammal tradition som karakteriseras av att lärlingen går bredvid mästaren och allt eftersom utför allt mer kvalificerade arbetsuppgifter. Mästarlära, ibland benämnt lärlingslära, är knutet till en arbetsplats där eleven i samspel med mer kvalificerade lär ett arbete. Inom mästarlära betonas att lärande sker genom deltagande i ett kulturellt sammanhang. När fokus flyttas från ett personcentrerat förhållningssätt som i mästarlära till ett decentrerat förhållande där praktikgemenskapen blir en avgörande faktor för lärande synliggörs lärandets sociala aspekt (Nielsen \& Kvale, 2000).

Gambles (2010) studie visar att den form av lärande som setts historiskt håller på att förändras. Den gamla mästertraditionen har ersatts med yrkeslärande på yrkesskola, kombinerat med praktik på företag, som en följd av vad som ses som svar på de ständigt föränderliga kraven på arbetsplatsen. Trots förändring i formen av lärlingslära skriver Gamble (2010) att det inte finns tecken på att hantverkslärande kommer att ske på annat sätt än genom "... a 'modelling' relationship between those already adpted in the craft and new initaties" (Gamble, 2010 s. 186).

När Gamble (2010) ifrågasätter vad det är som gör att lärlingstraditionen fortlever över generationerna trots de förändringar som skett kommer hon fram till att ett av svaren är det handlar om tyst kunskap. På arbetsplatsen finns det en betoning på att föra yrkeskunnandet vidare i form av yrkesidentitet. Yrkeskunnandet tillhör hantverkaren, inte förmannen eller företaget. Detta ses som en kvarleva av de medeltida skråna där lärlingen var direkt underställd mästaren. (Yrkes)kunskapen ligger inbäddad i en pågående praxis och visar därför alla tecken på tyst kunskap, med fokus på att praktisk behärska det kunnandet, så är det samtidigt en specialiserad kunskap i en form som överskrider ett visst sammanhang. Det är just därför att dessa förhållanden är underförstådda 
som de inte är möjliga att förklara explicit och uttalat och därför ofta beskrivs som ett mysterium (Gamble, 2010).

För att uppfylla utbildningskravet även under APL ska gymnasieskolorna använda läroplanernas mål som specificerar vad eleverna ska lära under utbildningen. Just denna tysta yrkeskunskap som bland andra Gamble (2010) beskriver finner Lundgren och von Schantz Lundgren (2012) att yrkeslärarna lär eleverna genom att använda sig av att visa, berätta och ställa frågor. Det är genom språket som yrkeslärarna förmedlar sina erfarenheter och yrkeskunnande genom att berätta om traditioner och historik och tala om de yrkesspecifika och ofta tysta kunskaperna som ligger i yrket. Lärarna förklarar, låter eleverna prova och öva för att utveckla det handlag som yrket kräver.

När undersköterskor berättar hur de har lärt sig yrket framkommer det att det är i det praktiska arbetet tillsammans med andra som yrket lärs. Det är i samspelet mellan äldre och yngre och mellan olika yrkeskategorier som lärandet sker vilket ger den kompetens som yrket kräver (Thunborg, 1999). Undersköterskor har precis som eleverna på Barn- och fritidsprogrammet gått en gymnasieutbildning och ska arbete inom servicesektorn med bemötande som ett viktigt inslag.

\section{Deltagande process}

Forskare har tittat på identitetsutveckling genom deltagande i arbete där de bland annat betonar att deltagande är en process som leder till medlemskap i en praktikgemenskap (Lave \& Wenger, 1991). För ett utförligare resonemang, se kapitel 4. Vid verksamheter som liknar den svenska gymnasieskolan och APL som kombinerar arbetsplatsförlagt lärande med yrkesskola handlar det inte om praktik och teori utan om två olika praktiker. Det handlar inte om kunskapsöverföring från skola till praktisk användning på arbetsplatsen utan om en process där eleven blir allt mer bekant med objekt och personer på arbetsplatsen (Tanggaard, 2007). Det centrala är att arbetsplatsen genererar en social miljö och ett ramverk för vilken kompetens som behövs (Groenwald m.fl., 2011).

\section{Reflektionens betydelse för lärande på arbetsplatsen}

Reflektion lyfts ofta fram som ett sätt att utveckla kunskaper och lära. Donald Schöns (1983) teori om den reflekterande praktikern har kommit att bli en ofta använd bild för hur kunskap utvecklas bland yrkeskunniga (se till exempel Lauvås \& Handal, 2001; Molander, 1996). Tesen är att tänkandet är knutet till specifika situationer och att tänkandet sker samtidigt som handlingen utförs. Schön betonar att det är den omedelbara kopplingen mellan handling och reflektion som leder till kunskapsutveckling och nytta för praktikern. Den reflekterande praktikern lär sig genom att pröva sig fram och upptäcka vad hon gör medan hon gör 
det. "Reflektion-i-handling" (reflection-in-action) är enligt Schön när den reflekterande praktikern prövar sig fram och upptäcker vad det är hon gör medan hon gör det. Reflektion av detta slag är ofta ordlös. Vid reflektion i handling skriver Schön att man diskuterar problemet med sig själv inom vissa bestämda ramar och att lösningen ofta handlar om att ifrågasätta dessa ramar. Att göra dessa, ofta omedvetna, ramar synliga och ifrågasätta dem är målet för reflektionen. Reflektion som sker direkt i handlingen skiljer Schön från "reflektion-över-handling" (reflection-onaction) som innebär att i efterhand reflektera över handlandet. Reflektionöver-handling är enligt Schön något som oftast sker när resultatet av en handling inte blev som man tänkt sig (Schön, 1983/1995).

Inom svensk forskning har bland andra Molander (1996) diskuterat att reflektion är att "... ta ett steg tillbaka för att se och tänka över sig själv och vad man gör, för att få perspektiv på en situation" (s. 143). Molander hävdar att reflektion kräver tid och är svårt att genomföra medan man är fullt upptagen med att genomföra handlingen. Det krävs distans till handlingen för att få perspektiv på den.

Att det råder en hel del olika sätt att tänka om begreppet reflektion visar en studie av Sundli och Söndenås (2007) kring trepartssamtal vid förskollärarutbildning. De finner att användningen av handledningsstrategier blir ett sätt att kontrollera eleven. Handledaren kan genom att reflektera tillsammans med eleven därigenom lotsa eleven fram till det svar som handledaren vill ha. Eleven kan komma att svara det handledaren vill höra istället för att utvecklas sin yrkesteori (Sundli \& Söndenås, 2007). Om yrkesutbildning till yrken som är av en reflekterad art, till exempel lärarutbildning, förläggs allt mer till arbetsplatsen kan det leda till att yrket reproduceras och inte utvecklas (Stenhouse, 1983; Carlgren, 1999; Lauvås \& Handal, 2001).

Vid arbetsplatslärande förekommer det ofta en erfaren person som har till uppgift att lära nykomlingen de för yrket viktiga kunskaperna. Inom förskolan kallas dessa personer för handledare, inom annan verksamhet kan de gå under beteckningar som mästare, tutor eller mentor. Det yrkeslärande som bedrivs på förskolor sker bland annat genom det som de inblandade kallar för handledning.

\section{Forskning om handledning}

Forskningen kring handledning är omfattande. Det här avsnittet kommer att behandla forskning om handledning generellt för att sedan gå vidare mot handledning för yrkeslärande och speciellt för yrken inom pedagogiska områden. 


\section{Handledning generellt}

Det råder en hel del olika åsikter om vad begreppet handledning innehåller. Begreppet används dessutom på många olika sätt inom många olika områden (Lauvås \& Handal, 2001; Åberg, 2009). Detta finner Lauvås och Handal (2001) i sin forskning bero på att handledning försiggår inom många olika yrkesgrupper (psykologer, socionomer, organisationskonsulter m.fl.). Handledning ses dessutom ofta som en vardagsaktivitet som vem som helst kan ägna sig åt och som inte är vikt bara för speciellt kvalificerade personer. Detta motsätter sig Lauvås och Handal (2001) som menar att det krävs mer än att bara vara bra på det som ska handledas i för att vara lämpad att utföra handledning.

De flesta definitioner av handledning faller tillbaka på Caplans studier på 1960-talet. Han definierar tre olika former av handledning som benämns konsultation, kollegialt stöd och supervision. Handledning som konsultation sker mellan erfarna yrkesmänniskor och innehåller inte någon form av bedömning av den verksamhet som utförs. Kollegialt stöd som handledning är när yrkesutövare söker stöd hos varandra och delar ansvaret för de beslut som tas. Inom det som definieras som supervision sker handledning i en hierarkisk situation. Den som får handledning befinner sig $i$ en underordnad position gentemot den som ger handledningen (Caplan, 1970). Handledning i denna studie kan liknas vid Caplans "handledning som supervision" eftersom det är en mer erfaren som handleder en person med mindre erfarenhet i syfte att lära ett yrke. Lauvås och Handal (2001) påpekar att Caplans forskning genomfördes på 1950- och 60-talet när "undervisning" definierades som en snävare verksamhet än vad den gör idag. Med en bred syn på undervisning går det mycket väl att se handledning som en form av undervisning.

\section{Två modeller för handledning}

Lauvås och Handal (2001) har genom sin forskning funnit två handledningstraditioner som används vid yrkeslärande. Modellerna är lärlingsmodellen som är en form av mästarlära och en modell som rör handling och reflektion. Handledning enligt lärlingsmodellen kännetecknas av att handledaren blir en förmedlare som hjälper lärlingen till rätta och ger den lagom svåra uppgifter. Denna situationsbetingade inlärning har sitt ursprung i yrkestraditioner där en hel del av kunskapen är tyst. Den kännetecknas av att bra praktikplatser är där det förekommer bästa möjliga praxis och handledaren är en skicklig yrkesutövare. Idén bygger på att praxis utgör modell och målet är att kopiera och bemästra en förlaga. Här blir handledaren mer en förmedlare av lagom svåra uppgifter. Handledaren ska demonstrera, ge tillfälle till övning och korrigera om eleven gör fel. Lärlingsmodellen har stark koppling till Lave och Wengers 
teori om lärande som situerad, en teori som utgör denna avhandlings teoretiska ramverk.

Den andra modellen att uppfatta hur yrkeslärande genom handledning på arbetsplats kan gå till (handling och reflektionsmodellen) är att den är en möjlighet att få pröva sig fram i yrket och få tillgång till situationer som underlag för reflektion. En bra praktikplats är här en där det förekommer allsidig praxis. Här blir handledaren en medreflekterande som är duktig på att tolka och analysera situationer. Idén är att praxis ska utgöra ett exempel och målet är att få insikt i hur yrket kan utföras. Den här, mer reflektionspräglade, modellen finns oftare i professionsutbildningar med vetenskaplig förankring (Lauvås \& Handal, 2001).

Dessa två modeller ger upphov till olika handlingar för handledaren. I lärlingsmodellen kommer handledningen att fokusera på handlingar; att demonstrera, öva och korrigera blir viktiga inslag. Handledarens roll blir även att kontrollera och bedöma elevens arbete. I handling och reflektionsmodellen kommer handledaren att, i en dialog med eleven där elevens frågor får styra, stödja eleven till kritisk granskning och kreativ kunskapsproduktion (Åberg, 2009). Lärlingsmodellen har kommit att kritiseras då ett antagande är att mäster inte lär av lärlingen. Jernström (2000) motsätter sig detta och skriver att det i lärlingsmodellen sker en utveckling och att mäster också lär av lärlingen.

När det på detta sätt finns olika sätt att uppfatta och tala om ett och samma begrepp är det av vikt att både utbildningsanordnare samt utförare har samma syn på begreppet. Utbildningens kvalité kan komma att påverkas om utbildningsanordnare vill att handledare ska fungera som "reflektionshandledare" medan de själva ser sig som "mästarlärare" (Lauvås \& Handal, 2001).

\section{Handledning för yrke}

Handledning för yrkeslärande bör innebära att man stöttar andra till att utveckla en egen praxisteori. Medvetenheten om den egna praxisteorin är relativt låg i många yrken. Den teori som används i praktiken kan sällan formuleras. Den som får handledning, även om det är en nybörjare, bär alltid med sig föreställningar, erfarenheter och kunskaper som ligger till grund för den personliga praxisteorin. Det är denna, för nybörjare ofta svaga, praxisteori som ska utvecklas genom handledning (Lauvås \& Handal, 2001).

Arbetet på förskola är av både pedagogisk och omvårdande karaktär. I kompetensbeskrivning för sjuksköterskor står det att sjuksköterskan måste kunna handleda sina medarbetare och studenter (Socialstyrelsen, 2005). Något liknande finns inte för förskoleområdet. Vad gäller handledning inom omvårdnadsutbildning finns mycket forskning (Brammer, 2006; Näf, 1999; Petersson \& Vahlne 1997; Benner, 1993; 
Öhrling, 2004). För att bli sjuksköterska krävs att de teoretiska kunskaperna får praktiseras och övas inom ramen för utbildningen för att sedan kunna utföras självständigt med det ansvar som sjuksköterskan har. Handledaren kan underlätta studenternas lärande på många sätt (Öhrling, 2004). Det finns många sätt att ta sig an handledaruppdraget. Hur sjuksköterskor uppfattar och tar sig an sin handledarroll påverkar studenternas lärande. Bland olika handledare finns det de som är väldigt fokuserade på studenternas behov till de som uppger att de helst inte vill vara handledare (Brammer, 2006).

I en försöksmodell där läroplanen för de yrkesförberedande programmen inom kommunal vuxenutbildning tillämpades tillsammans med yrkesträning på en arbetsplats konstaterades att de handledare som deltog i den studien inte såg sig själva som pedagoger. I detta fall var handledarna verkstadsarbetare utan pedagogisk utbildning (Höghielm, 2005). De handledare som fokuseras i den här studien har däremot alla någon form av pedagogisk utbildning och kan alla anses vara pedagoger.

Inom övrig forskning kring handledning kopplat till yrkeslärande är grupphandledning ett populärt tema (Hammar Chiriac, 1999, 2010; Näslund, 2010). Denna form av handledning sker ofta för personalens fortsatta lärande inom yrket och faller utanför mitt fokus. Handledning i skolsammanhang handlar ofta om basgruppshandledning och handledning i klassrummet, vilket även det faller utanför avhandlingens intresseområde (Lundström, 2007). Där är det handledning i den klassiska skolsituationen som beskrivs, medan denna studie studerar handledning kopplad till yrkesutbildning. Om handledning inom universitet och högskola finns det mycket publicerat (Eriksson, 2007; Lindén, 1998; Magnusson, 2002). Att vara handledare, och speciellt forskarhandledare, handlar om att ha en förmåga att variera handledningen efter de studerandes individuella utveckling och behov (Lindén, 1998).

\section{Handledning för yrken inom pedagogisk verksamhet}

Handledning inom pedagogisk verksamhet handlar exempelvis om lärarstudenter som gör sin praktik som vanligen benämns verksamhetsförlagd undervisning (VFU). Lärarutbildningen har utvecklats från början av 1900-talet från att ha karaktär av en lärlingsmodell till att vara mer av en vetenskaplig förankrad modell. De direktiv som har funnits för att styra handledningen under VFU har varit av mer teknisk och administrativ karaktär än av pedagogisk karaktär. Målet för många handledare har varit att lära ut ett etablerat yrkesmönster enligt en mästartradition. Lärarstudenterna ska lära metoder och tekniker för undervisning inom tämligen fasta ramar. Handledningen är inriktad mer mot ytliga karaktäristika än tänkandet om lärandet (Franke, 1990). 
Enligt lärare som fungerat som handledare för lärarkandidater är det under praktik som yrket och ett speciellt förhållningssätt ska läras. Detta förhållningssätt lärs genom samspelet mellan student - lärare - elever. En av svårigheterna som Hultman, Schultz och Stolpe pekar på med att lära läraryrket är att det finns ett gap mellan teori och praktik som studenterna har svårt att överbrygga. Den studerande måste ta del av något som inte är direkt överförbart via texter utan som sker i ett sampel. Hur detta relationsskapande arbete går till och hur lärare lär sitt hantverkskunnande saknas det studier om (Hultman, Schultz och Stolpe, 2011).

Sedan 1990-talet har Handal och Lauvås handledningsstrategi varit tongivande i svensk och norsk handledning för läraryrket (Åberg, 2009). Deras modell för lärande till lärare är att studenten genom handledning ska få hjälp att bli medveten om sin praxisteori genom reflektion (Lauvås \& Handal, 2001). De som hävdar att färdighetsträning är en viktig del i yrket påpekar att övandet får för lite utrymme i modellen. Handledaren som den goda modellen försvinner och det blir upp till den studerande att hitta sitt sätt att utföra yrket på (Åberg, 2009).

\section{Handledare i ett europeiskt perspektiv}

Yrkesutbildning och det arbetsplatsförlagda lärandet diskuteras även på EU-nivå. En studie omfattande 32 europeiska länder visar att det finns mycket lite forskning kring handledare. En orsak till detta är att handledaruppdraget inte definieras och redovisas som en arbetsuppgift i statistiken. Handledaruppdraget ses som en roll och inte som ett professionellt uppdrag. Detta får konsekvenser för handledarnas vidareutbildning. Handledarutbildningar når inte handledarna eftersom de inte identifierar sig som sådana. I länder med hög arbetslöshet (lätt att få tag på arbetskraft) är företagsutbildning mer osynlig medan i länder med låg arbetslöshet är företag mer benägna att ha en utarbetad strategi för kompetensförsörjning genom bland annat handledning för praktikanter och nyanställda. Studien visar även att de flesta länder inte har några kvalifikationskrav som handledarna ska uppfylla. Det har däremot länder med stark lärlingstradition (så som exempelvis Tyskland och Österrike). Där behöver handledare vara både kvalificerade yrkesmänniskor som kan styrka sin förmåga att arbeta med ungdomar och ha pedagogisk kompetens. En handledare behöver enligt studien ha tre kompetensnivåer för att vara handledare. Den första är yrkeskompetens, den andra är pedagogisk och social kompetens för att kunna underlätta didaktiska processer så som att främja lärande, övervaka och integrera delar och att effektivisera överförandet av kunskap. Den tredje nivån är ledningskompetens för att övervaka och granska kvalité, samt samarbeta med olika delar av företaget/organisationen. Studien visar att de flesta länder kräver att handledarna har goda yrkeskvalifikationer medan de 
flesta länder saknar krav på pedagogiskförmåga och ledningskvalifikationer. Många länder har insett värdet av pedagogisk och social kompetens hos handledarna och har påbörjat arbete med att stärka dessa genom utbildning för handledare. Studien visar även att synen på handledarrollen har genomgått flera förändringar. Bland annat har handledarrollen gått från att ses som en auktoritet och "instruktör" till att nu mera ska fungera som "coach" eller "kontaktperson". Förändring av detta slag gör att det idag ställs andra krav på handledaren. Det krävs andra sätt att kommunicera och interagera i samarbete, vid mentorskap och för att underlätta för nya former av lärande idag. Vidare visar studien på förändringar $\mathrm{i}$ handledarnas ansvarsområden med mer ansvar för projektorienterat lärande, kvalitetsbedömning och komplext koordinerande med andra utbildningsanordnare. Handledarna är ofta inte kvalificerade och förberedda att realisera dessa nya uppgifter och de förändrade förväntningar som finns på dem. Slutsatsen är att detta är en stor utmaning för framtiden (Kirpal \& Tutschner, 2008).

\section{Sammanfattning av perspektiv på yrkesutbildning och handledning}

Tidigare forskning visar att Barn- och Fritidsprogrammet är ett lågstatusprogram med en heterogen elevgrupp och en homogen lärarkår där inte alla lärare har utbildning för de kurser som de undervisar inom (Lemar, 2001). Förskolan är en traditionellt kvinnlig värld där formandet av yrkesidentitet har varit centralt under förskollärarutbildningen (Tallberg Broman, 1991). Att lära ett yrke på arbetsplatsen kan fungera bra om arbetsplatsen bland annat kan uppvisa en bred bild av yrket. Det kan finnas risk att lärande på arbetsplatsen stannar vid att bli reproduktivt (Ellström, 1992; Fuller \& Unwin, 2004). Arbetsplatslärande, som också kan benämnas mästarlära och lärlingslära, är en gammal tradition som lever kvar och bland annat beskriver hur yrkesidentiteter formas i sampel mellan nykomlingen och den erfarne mästaren. Att lära ett yrke kan ses som en deltagande process där det viktiga är att komma in i gemenskapen och bli bekant med arbetsplatsen (Lave \& Wenger, 1991). För att stimulera det utvecklingsinriktade lärandet på arbetsplatsen är reflektion ett sätt (Schön, 1983/1995; Molander, 1996). Genom att, antingen direkt i handlingen eller efter genomförandet, diskutera kring vad som skedde bildas ny kunskap.

I den här studien används Caplans (1970) definition av handledning som "supervision" som sker enligt en hierarkisk modell. Lauvås och Handals (2001) handledningsmodeller beskriver hur olika två olika former för handledning går till. Handledning för yrkeslärande går framförallt ut på att nykomlingen ska utveckla en egen yrkesteori. Handledning för arbete 
inom pedagogisk sektor har gått från att ske enligt en lärlingsmodell till att allt mer rikta fokus mot att nykomlingarna lär genom reflektion.

Med allt mer fokus på att fungera som en stöttande person som ska hjälpa nykomlingen att själv utveckla sin yrkesteori ställs det idag andra krav på handledare än att bara vara duktiga yrkesmänniskor. Vid en jämförelse med länder med stark tradition av arbetsplatsförlagd lärlingsutbildning ställs det där högre krav på handledarnas kunskaper och kvalifikationer och de ska bland annat vara goda pedagoger (Kirpal \& Tutschner, 2008). 


\section{Teoretiskt perspektiv}

I följande kapitel beskrivs och diskuteras studiens teoretiska utgångspunkter. Studien utgår från ett sociokulturellt perspektiv på lärande med hjälp av Lave och Wengers teorier om situerat lärande och med fokus på framförallt begreppen praktikgemenskaper (Communities of Practice) samt legitimt perifert deltagande (Legitimate Periphal Particpation) kommer studiens resultat att diskuteras. Dessa begrepp ger redskap för att analysera lärande genom situerat deltagande och hur nykomlingar introduceras i yrken. Att anlägga ett perspektiv ska här ses som ett sätt att rikta uppmärksamheten mot något snarare än en konkret beskrivning på hur något kan göras.

\section{Situerat lärande}

Ett sociokulturellt perspektiv på lärande innebär att allt mänskligt lärande ses som något som sker i ett kommunikativt och sociohistoriskt perspektiv. Kunskap blir till genom deltagande och i möten och samspel mellan människor för att därefter bli en del av individen och dennes tanke och handling. I sociokulturell teori är problemet med hur människor lär en fråga om hur vi tar till oss de redskap och resurser som är en del av vår kultur och vår omgivning (Säljö, 2000). Kunskap handlar om kompetens i förhållande till en aktivitet och deltagande i den aktiviteten. Lärande sker genom deltagande, där nykomlingens deltagande kan ses som en rörelse från periferin mot ett fullvärdigt deltagande i praktikgemenskapen. Jämfört med att se på lärande som en enskild process som pågår i hjärnan sker lärande, med ett situerat perspektiv, i alla sammanhang och som en ständigt pågående process. Genom kommunikation skapas och förs kunskaper vidare. I språket lagras kunskap och insikter hos individer och kollektiv. De medaktörer som vi kommer i kontakt med hjälper oss i samspel att förstå hur världen är organiserad (Wenger, 1998).

\section{Praktikgemenskaper}

Praktikgemenskaper består av människor som ömsesidigt engagerar sig i ett gemensamt uppdrag. Inom varje praktikgemenskap finns det en gemensam arena vilken i detta sammanhang är förskolan. I avhandlingen ses praktikgemenskapen både som den enskilda förskolan där handledaren arbetar och även som den svenska förskolan som helhet. Att se förskolan som en praktikgemenskap betyder i denna studie att förskolan behandlas som en plats där människor interagerar med varandra och är en plats och en funktion som existerar i samhället idag. 
Medlemskap i praktikgemenskapen innebär ett engagemang för ett gemensamt syfte. Detta ömsesidiga engagemang i en verksamhet innebär att människor hela tiden gör saker tillsammans och under tiden gemensamt förhandlar om meningen med det som görs (Wenger, 1998). På förskolan handlar detta gemensamma engagemang om att bedriva pedagogisk verksamhet för barn och att realisera de mål läroplanen för förskolan sätter för verksamheten med hjälp av de resurser som står till förfogande. Tillsammans formar arbetslaget verksamheten på förskolan genom ett ömsesidigt engagemang och genom förhandling kring mål och mening. De personer som arbetar i förskolan ses här som "old-timers" med erfarenhet av praktikgemenskapen (Wenger, 1998).

För att kunna engagera sig i verksamheten krävs att man blir inkluderad i praktikgemenskapen. Denna inkludering bygger på nykomlingens engagemang. I en praktikgemenskap samlas deltagare med olika bakgrund och intresse där varje deltagares tidigare erfarenheter är med och skapar mening med praktikgemenskapen. Alla dessa deltagare binds samman av relationer mellan varandra (Wenger, 1998).

Förhandling om uppdraget

Varje praktikgemenskap existerar i en historisk, social, kulturell kontext. Varje förskola och dess medarbetare finns på detta sätt i ett lokalt, kommunalt, nationellt och internationellt, historiskt och kulturellt sammanhang som påverkar den enskilda förskole enheten på olika sätt. Inom praktikgemenskaper förhandlar deltagarna ständigt med varandra om uppdraget, i detta exempel om hur förskoleverksamhet ska genomföras, i det som kan liknas vid en kollektiv förhandlingsprocess oberoende av de faktorer som ligger utanför deltagarnas makt att påverka (Wenger, 1998). De olika förutsättningarna för varje förskola, individerna i gemenskapen och deras olikheter gör att det sätt på vilket personalen på förskolan kommer att genomföra uppdraget skiljer sig åt mellan varje enhet. Genom att deltagarna förhandlar om uppdraget utvecklar de tillsammans en gemensam repertoar av rutiner, ord, verktyg, gester och symboler typiska för deras gemenskap. Eftersom en sådan form av repertoar alltid är under omförhandling öppnar engagemang upp för deltagande och förändring av praktikgemenskapen. Varje ny medlem tar med sig något nytt in i praktikgemenskapen som bidrar till och förändrar den. Genom denna förhandling är det inte bara nykomlingarna som lär utan även de erfarna får ompröva sina tidigare ställningstaganden och sätt att använda redskap eller sätt att utför uppgifter på. På så sätt förändras praktikgemenskapen genom förhandling (Wenger, 1998).

Deltagande och meningsskapande

I situerat lärande består begreppet deltagande av mer än att bara delta, det förutsätter ett aktivt engagemang. För att kunna engagera sig i en uppgift behöver hela människan finnas med i processen. Meningen med 
den verksamheten som praktikgemenskapen består i skapas tillsammans vid deltagande i praktikgemenskapen. Meningen med en uppgift innehåller två delar, deltagande och reifikation (att behandla mänskliga upplevelser som verkliga - förtingliga). Termen reifikation används för att täcka in en rad processer som till exempelvis skapande, utformande, benämnande, beskrivande, tolkande och användande. Reifikation skapar vår erfarenhet, att till exempel använda ett verktyg för att utföra en aktivitet ändrar aktivitetens natur. En miniräknare "reifierar" aktiviteten räkna. Deltagande och reifikation bygger på varandra och är två dimensioner av samma sak som interagerar. De samspelar med varandra och kan inte översättas med varandra (Wenger, 1998).

Att delta i en aktivitet förutsätter att aktiviteten är kopplad till andra människor. Deltagande är kopplade till både göra, tänka, prata, känna och tillhöra. Detta deltagande formar individerna precis som de i sin tur formar omgivningen. Deltagande blir meningsskapande då det formar en del av den identitet som människor sedan tar med oss när de lämnar praktikgemenskapen (Wenger, 1998).

Förutom att delta kan även reifikation skapa mening med det som görs. Alla praktikgemenskaper producerar abstrakta verktyg, symboler, termer och koncept som blir konkreta (förtingligas) i form av artefakter som till exempel verktyg eller, som i förskolan, en läroplan. Läroplanen kan ses som en sammanhållande länk som ska styra verksamheten, en artefakt som reifikation av praktikgemenskapen. Deltagande och skapandet av artefakter går hand $\mathrm{i}$ hand och kan inte separeras från varandra. Vårt deltagande formas bland de reifikationer som är producerade i det specifika sammanhanget (Wenger, 1998). Förskolan är på detta sätt fylld av begrepp och verktyg som har vuxit fram i samspel mellan människor och reifikationer i olika former.

\section{Identitetsskapande}

Det finns en stark koppling mellan identitet och praktik. Vilka vi är handlar om hur vi lever varje dag. I praktiken definieras identiteter eftersom de är skapade i en social kontext. Handledaren får på så sätt sin identitet som sådan i samverkan med APL-systemet och gymnasieeleven. Genom APLsystemet får nykomlingen (gymnasieeleven) legitim tillgång till en gemenskap som karaktäriseras av gemensamma mål, föreställningar och värderingar. Detta ger nykomlingen en möjlighet att skapa sig en identitet. Identiteter är inte något som finns från början utan som kontinuerligt skapas och omförhandlas i samspel med andra. Genom deltagande i praktikgemenskaper utvecklar medlemmarna sina identiteter. Som medlem i gemenskapen får individen en förståelse för vad som förväntas där och kan utföra dessa uppgifter. Förskolan som praktikgemenskap formar eleverna och deras identiteter till att bli "förskolepersonal" precis som eleverna formar verksamheten tillsammans med övrig personal. En 
person kan tillhöra många olika praktikgemenskaper samtidigt, vara fullvärdig medlem i en och perifer i en annan. En identitet är upplevd, förhandlad, social, en lärprocess och finns i ett sammanhang (Wenger, 1998).

Kommunikation är den länk via vilken kulturella föreställningar förs vidare. Det är också länken mellan kulturen och hur människor tänker. I ett sociokulturellt perspektiv kan tänkande vara en kollektiv process som sker mellan människor likväl som inom dem. Tänkandet är något som människor deltar i när de tillsammans med andra diskuterar sig fram till exempelvis lösningar på problem (Wenger, 1998). Gemensamt tänkande kan på förskolan vara när personalen tillsammans planerar och utvärderar verksamheten, träffar stödpersoner och chefer.

\section{Legitimt perifert deltagande}

För att beskriva den väg som nykomlingar tar för att bli fullvärdiga medlemmar i praktikgemenskap använder Lave och Wenger (1991) begreppet Legitimt perifert deltagande. Genom att använda begreppet är det möjligt att diskutera relationerna mellan nykomlingar och erfarna, mellan aktiviteter, identiteter, artefakter och praktikgemenskaper. En person som befinner sig i en lärprocess på en arbetsplats genomgår en förändringsprocess för att bli en fullvärdig medlem i en sociokulturell praktik (Lave \& Wenger, 1991). Denna sociala process förutsätter lärande av praktiska yrkesfärdigheter. "Perifert deltagande" ska här ses som att finnas i ett sammanhang och som har relevans till den pågående aktiviteten. Eleven är i detta fall en nykomling och legitimt perifer deltagare inom praktikgemenskapen förskolan.

Praktikgemenskaper omfattar en triad av nykomlingar, nyligen utbildade och mästare med erfarenhet på området. Lärande och reproducering av gemenskaper står $\mathrm{i}$ ett problematiskt förhållande till varandra. Det existerar samtidigt krafter som verkar både för och mot utveckling och lärande i praktikgemenskapen. En förutsättning för lärande är att eleven kommer åt den praktikgemenskap som åsyftas. Lärande i en praktikgemenskap sker i en rörelse där nykomlingen genom deltagande kommer att röra sig allt mer mot fullvärdigt medlemskap i praktikgemenskapen. Nyckeln till detta deltagande är om nykomlingarna får tillgång till gemenskapen och allt vad det innebär. För att främja lärandet är det därför viktigt att elever/nykomlingar får tillgång till alla delar av den kunskap som existerar inom gemenskapen. APL-systemet och handledaren öppnar dörren för detta legitima deltagande. Mycket av lärandet sker genom att höra hur mäster/handledaren talar om det som lärs. Det är inte så mycket vad handledaren pratar om, utan mer hur handledaren genom historier och berättelser sätter ord på det som sker som nykomlingen förstår yrket. Att lära sig att kommunicera med 
yrkesspråk är en nyckel till legitimt perifert deltagande (Lave \& Wenger, 1991).

Genom att vara legitim perifer deltagare får eleverna tillgång till en autentisk miljö inom det område som studeras. Eleverna möter en fungerande verksamhet som innehåller alla de delar som studeras och ska läras. Genom att delta i arbetet med små uppgifter får eleven möjlighet att se hur "slutprodukten" kan/ska se ut. Resan mot en mer deltagande roll i produktionen innebär inte bara svårare och längre arbetsuppgifter, mer ansvar och högre risker utan även, och mer signifikant, en ökad känsla av identitet som mästare (Lave \& Wenger, 1991).

Denna rörelse inom praktikgemenskapen leder inte alltid till fullvärdigt medlemskap. Nykomlingar som börjar sin bana, eller här APL, med uttalat syfte att bli fullvärdiga medlemmar kan ha en inåtgående deltagarbana som understöds av alla inblandade. För vissa deltagare kan denna deltagarbana emellertid vara riktad utåt. Vidare kan även fullvärdiga medlemmars deltagande utryckas i form av deltagarbanor. Nya arbetsuppgifter, redskap eller krav påverkar allas deltagande och därmed även deras identiteter. Som nykomling sker alltså lärandet genom att delta legitimt i verksamhetens periferi. Genom att få delta men "se verksamheten på håll" kan nykomlingen lära för att sedan så småningom delta fullt ut. Den elev som blir lämnad eller placerar sig själv i marginalen kan ha svårt att komma åt det lärande som senare möjliggör fullt deltagande. Vad som avgör om det är en inåtgående deltagarbana eller om deltagaren blir kvar ute i marginalen beror enligt Lave och Wenger bland annat på hur människor placerar sig i det sociala landskapet, vad som ses som viktig och vad som är viktigt att lära. Även med vilka vi söker kontakt, hur vårt engagemang ser ut och hur vi försöker påverka vår deltagarbana kommer att spela in på om en person kommer in $\mathrm{i}$ gemenskapen som fullvärdig medlem (Lave \& Wenger, 1998) Handledaren har i det här sammanhanget som min studie fokuserar på en central position som möjliggör eller begränsar gymnasieelevernas möjlighet att komma in i praktikgemenskapen på förskolan.

Valet av sociokulturellt perspektiv och situerat lärande innebär att intresset i avhandlingen riktas mot hur handledarna erbjuder och hanterar elevernas deltagande i verksamheten. Fokus ligger bland annat på de olika sätt som deltagandet organiseras av handledarna.

\section{Teoridiskussion}

När Lave och Wenger utvecklade sitt teoretiska ramverk kring Communities of Practice skedde det efter perioder av antropologiska studier i olika sammanhang där lärlingar under lång tid deltog i verksamheter (bland annat hos skräddarlärlingar i Afrika och hos 
Anonyma Alkoholister) (Lave \& Wenger, 1991). När jag i denna studie använder deras resonemang för jag över det på en verksamhet som delvis skiljer sig från deras arbete. För det första är eleverna från gymnasieskolan ute på APL under kortare perioder än de lärlingar som Lave och Wenger studerade. De speciella kännetecken som gör att teorin fungerar i mitt exempel är att eleverna under sin APL-period är satta att lära, genom deltagande i en praktikgemenskap med hjälp av handledare som kan ses som så kallade "oldtimers" med erfarenhet och kunskap som är viktiga för praktikgemenskapen.

Eleverna på BF har i stor utsträckning själva gått på förskola och funnits i barnomsorgen på olika sätt under många år. Att då prata om eleven i termer av "nykomling" i sammanhanget kan bli missvisande men det handlar om att vara nykomling i den gemenskap som utgörs av förskolans personal. Att nykomlingar kan komma till praktikgemenskapen med värdefull kunskap och som nykomlingar bidra till utveckling visar också Fuller och Unwin (2004) när de därmed kritiserar Lave och Wengers teori i de delar där denna ser alla noviser som legitima perifera deltagare och alla experter som fullt legitimt deltagande i praktikgemenskapen. Fuller m.fl. (2005) visar att även de erfarna arbetarna lär tillsammans med och av nykomlingarna. Nykomlingar kommer idag till arbetsplatsen med en uppsättning kunskaper och erfarenheter som de har fått genom tidigare arbete och (ofta) längre skolgång och kan därigenom påskynda utveckling i praktikgemenskapen (Fuller m.fl., 2005).

Att yrkesutbildning på skola jämfört med på arbetsplats skulle vara frågan om två olika verksamheter emotsäger bland andra Hodkinson (2005) och Berner (2010). Det är ett förenklat sätt att se på bilden av yrkeslärande i minst två avseenden. För det första är skillnaderna mellan lärande på arbetsplatsen och i skola enligt dem överdrivna och beror på att definitionen av både "praktikgemenskaper" och "skola" är för snäv. Hodkinson (2005) föreslår att utvidga begreppet praktikgemenskaper till ett som inkluderar Bourdieus fältbegrepp där skola och arbetsplats ses som ett vidare, komplext socialt spel där alla människor är engagerade. Då blir det lättare att se på lärande i relation till ojämn maktfördelning, kulturellt, socialt och ekonomiskt kapital (Hodkinson, 2005). För det andra är det en allt för snäv syn på skola eftersom den sällan analyserar skolbaserad yrkesträning (Berner, 2010). Den skolbaserade yrkesträningen, skriver Berner, sker i intensiv samverkan mellan lärare - elev verktyg/maskin och svarar mot en väl definierad arbetsmarknad. Om man här ersätter begreppet "verktyg/maskin" från Berners exempel med "barn" vill jag påstå att ett speciellt kännetecken på BF kvarstår. Barnen finns inte i gymnasieskolan och verkstaden, de finns i förskolan, och yrkesträning i Berners mening kan inte ske på gymnasieskolan. Vidare skriver Berner (2010) att man ofta bortser från att yrkeslärarna har en omfattande 
bakgrund som yrkesverksamma. Motsatsen visar dock Fejes och Köpsén (2014) och Tsagalidis (2009) som funnit att yrkeslärare med kort tid som yrkesverksam och lång tid som lärare kan befinna sig långt från den yrkesgemenskap som de undervisar för. Ett skolbaserat yrkeslärande har ändå sina poänger påpekar Hodkinson, Biesta och James (2008), då de bland annat skriver att yrkesskolor är till för just yrkeslärande och inget annat. På arbetsplatsen finns heller inte pedagogiskt utbildad personal som bara är där för elevernas skull.

En vanlig kritik mot Lave och Wengers teoretiska ramverk är att de inte tar upp kön, maktförhållanden och konflikter (Contu \& Willmott, 2003; Huzzard, 2004; Salminen-Karlson, 2006; Tanggaard, 2006). Inga praktikgemenskaper är könsneutrala och hur identiteter formas är alltid av vikt. Att vara nykomling bär alltid med sig en könsaspekt och kvinnor och män kommer att ha olika möjligheter att delta i praktikgemenskapen (Salminen-Karlson, 2006). Huzzard (2004) kritiserar Lave och Wenger och hävdar att de inte problematiserar makt. Han skriver att lärande är en produkt av makt och problematiserar frågan genom tre påståenden. För det första, skriver han, att ojämlikhet i makt är positivt för att styra lärandet i projekt åt det håll som projektets ramar tillåter. För det andra förstärks lärandet när hierarkier (tillfälligt) sätts ur spel och för det tredje kan en produkt av lärande vara att nya maktrelationer utvecklas.

Trots de beskrivna svagheterna i teorin och andra sätt att använda den jämför med hur jag använder den i detta sammanhang visar denna studie att den fungerar bra för att förklara nykomlingars väg till fullvärdigt medlemskap i en praktikgemenskap och hur de människor de möter under denna resa kan stötta eller förhindra deltagandet i rörelsen mot att bli en fullvärdig medlem.

\section{Sammanfattning av teoretiskt perspektiv}

Syftet med det här kapitlet har varit att skissa en bild av studiens teoretiska angreppssätt. Med ett sociokulturellt perspektiv blir kunskap till genom deltagande och i kommunikation mellan människor. Lärande blir en fråga om hur människor tar till sig de redskap och språk som omger situationen. Situerat lärande finns alltid i ett sammanhang. Centralt i studien är Wengers (1998) begrepp praktikgemenskaper. I en praktikgemenskap engagerar sig människor tillsammans för ett gemensamt syfte. Genom detta engagemang förhandlar deltagarna tillsammans om hur och vad som ska göras. Denna förhandling kommer att resultera i ett gemensamt språk och repertoar av handlingar. Deltagandet i praktikgemenskapen påverkar även deltagarnas identiteter precis som deltagarna kommer att påverka gemenskapen. Varje praktikgemenskap kommer att producera 
reifikationer, förtingligade produkter som har vuxit fram som ett resultat av praktikgemenskapens gemensamma historia.

Som ny i en praktikgemenskap tar det tid för individer att bli fullvärdiga medlemmar. För resan mot fullvärdigt medlemskap använder Lave och Wenger (1991) begreppet Legitimt perifert deltagande som kan beskrivas som en process av lärande genom deltagande i en specifik gemenskap. 


\section{Metod}

I följande kapitel diskuteras de metodologiska val jag har stått inför i utformandet av detta projekt. Vidare beskrivas tillvägagångssättet vid datainsamlingen samt hur dessa har analyserats. När ett forskningsprojekt ska designas står forskaren inför många val. Det är viktigt att välja en metod som matchar vad forskaren vill veta och vara tydlig med vilka val som har gjorts och varför (Braun \& Clarke, 2006; Bryman, 2001; Larsson, 2011).

\section{Design}

I detta arbete är syftet av kvalitativ art. Det vill säga att intresset ligger på de kvalitativa beskrivningarna av hur handledning och yrkesutbildning går till, inte på hur ofta något fenomen uppträder eller hur många som tycker något (Bryman, 2001).

\section{Kvalitativa semistrukturerade intervjuer}

Som metod för att uppnå syftet valde jag att genomföra kvalitativa semistrukturerade intervjuer. Denna form av intervjuer tillät mig att vara flexibel inför att låta informanternas upplevelser styra intervjun och samtidigt behålla fokus på det önskade (Bryman, 2001). Kvale och Brinkmann (2009) skriver även att: "Den kvalitativa forskningsintervjun söker förstå världen från undersökningspersonernas synvinkel, utveckla mening ur deras erfarenhet, avslöja deras levda värld som den var före de vetenskapliga förklaringarna." (s. 17). Semistrukturerade intervjuer liknar ett samtal men med ett speciellt syfte och genomförs enligt en tematiserad intervjuguide med förslag på frågor (Kvale \& Brinkmann, 2009).

\section{Skapande av intervjuguide}

Vid skapandet av intervjuguiden inledde jag med att skriva ner ett antal centrala teman som jag ville beröra under intervjun. Dessa var till exempel vad eleverna lär sig under APL, vad handledarna ansåg att de hade för uppgift och betydelse för elevernas lärande samt hur handledning bedrevs. Utifrån dessa huvudfrågor skrev jag ner ett antal underfrågor som jag ville ha belysta under samtalet.

\section{Urval}

För att hitta mina informanter började jag med att begära tillstånd hos skolchefer i två olika kommuner. Valet föll på en stor kommun och en mindre kommun med landsortsprägel. Med skolchefernas godkännande 
gick jag vidare till de APL-ansvariga på två gymnasieskolor som tillhandahöll namn på förskolepersonal som brukar fungera som handledare. Med dessa handledares chefers godkännande kontaktade jag handledarna per telefon. Detta sista led gjordes via telefon men innan dess skedde kommunikation mestadels via e-post.

Antalet informanter var inte bestämt på förhand, intervjuerna bokades och genomfördes löpande. När jag hade intervjuat 20 informanter ansåg jag att det fanns en tillräcklig mättnad i materialet (Kvale \& Brinkmann, 2009). Det är inte säkert att det går att få en bredare bild av ett fenomen genom att fråga fler om deras åsikter men det ökar forskarens känsla av att materialet är tillförlitligt (Boyatzis, 1998). Här bedömdes alltså 20 intervjuer utgöra ett tillräckligt material. Av de 23 intervjupersoner jag kontaktade tackade två nej direkt i telefon och en ville fundera mera och hörde inte av sig igen. De 20 som intervjuades tackade ja mer eller mindre direkt.

Av informanterna är 19 kvinnor och en man. Enligt SCB (2013) är 3,5 procent av de anställda inom barnsomsorgen män. Mannen i urvalet utgör 5 procent av informanterna. Jag intervjuade 12 barnskötare och 8 förskollärare. Flera av informanterna hade börjat sin bana inom förskolan som barnskötare och sedan vidareutbildat sig till förskollärare. Den yngsta var 24 år och hade vid intervjutillfället arbetat i 1,5 år. Den äldsta var 63 år och hade 30 års erfarenhet av arbete i förskola. Den med längst erfarenhet hade arbetat 40 år inom barnomsorgen. Medelåldern bland mina informanter är 50 år och i genomsnitt har de 23 års erfarenhet av arbete inom förskola. Samtliga informanter är anställda på kommunala förskolor.

Som tidigare beskrivits arbetar det på förskolan två olika yrkeskategorier, förskollärare och barnskötare, med olika utbildning och lön men med liknande arbetsuppgifter. På de listor som jag fick tillgång till fanns inte utbildning med, när jag kontaktade informanterna visste jag bara att de brukade fungera som handledare för elever från Barn- och fritidsprogrammet. Det kan mycket väl diskuteras vad handledarnas utbildning innebär för deras arbete som handledare men jag har i denna studie valt att bortse från detta och fokusera på deras beskrivningar av handledaruppdraget.

\section{Genomförande}

Efter att informanterna per telefon hade tackat ja till att medverka bestämde vi dag och tid för träff. Informanterna fick styra tidpunkten och platsen för mötet, ofta skedde intervjuerna i anslutning till handledarnas arbetstid och arbetsplats. De flesta var nyfikna och förväntansfulla när jag kom för att intervjua dem. En slutsats som dras av detta är att de har velat berätta sin historia och tycker att detta är ett viktigt område som de vill dela med sig av. Här skulle gruppen "handledare" kunna få komma till tals. Att 
på detta sätt ta ett "aktivistperspektiv" har varit populärt inom forskning (Hiller \& DiLuzio, 2004). Det är viktigt att komma ihåg att bara för att man lyssnar på en grupp är det inte det samma som att man förstår den gruppen eller hur de uppfattar forskningsprocessen. Genom att intervjua handledarna vill jag här få deras bild av den verksamhet som de bedriver för gymnasieeleverna men jag har ingen makt att förändra deras situation. En annan slutsats som kan dras är att handledarna gärna ville ha en bekräftelse på att det de gör är bra. För att informanten skulle ha tid att bekanta sig med mig före intervjun inledde jag alltid mitt besök med att i positiv bemärkelse kommentera förskolan, dess inne- eller utemiljö eller ställa en fråga om något och uppmärksamma om det var något speciellt de ville visa eller berätta (Hiller \& DiLuzio, 2004).

Intervjuerna inleddes alltid med att jag beskrev syftet med studien samt berättade att deltagandet var frivilligt och att de när som helst kunde avbryta sitt deltagande. Öppningsfrăgan ställdes lika till alla för att ange vad som skulle vara i fokus men därefter kom inte frågorna i någon speciell ordning. Under intervjun försökte jag medvetet förhålla mig naiv till informanternas berättelser (Kvale \& Brinkmann, 2009). Med flera års erfarenhet av förskola, och att möta handledare och elever ute på förskola ville jag ge varje handledare möjlighet att berätta sin egen historia och inte lägga in mina för givet taganden i deras berättelser. Medveten om min förförståelse försökte jag följa upp resonemang och svar med sammanfattningar följda av frågan om det var så de menade. Jag frågade ofta, fast jag trodde mig förstå, frågor som "Hur kommer det sig?" "Berätta mer om hur du menar?" för att få informanterna att beskriva mera. Reflexiv progression är en term som används när informanten på intervjuarens uppmaning på detta sätt förklarar sina tankar och observationer (Kvale \& Brinkmann, 2009; Hiller \& DiLuzio, 2004; Denzin, 2001). De flesta intervjuer varade cirka 50 minuter. Någon över en timme och den kortaste 35 minuter på grund av intervjupersonen hade en sjuk kollega och det rådde brist på vikarier.

Det var tydligt för mig i mina intervjuer hur informanterna kunde uttrycka sig mer ju längre intervjun varade. Kunskap växte fram medan intervjuerna pågick. Frågor ledde till funderingar som informanten inte har tänkt på och därigenom skapades och tolkades världen där och då (Hiller \& DiLuzio, 2004).

\section{Analysmetod}

För att analysera de resultat som de transkriberade intervjuerna erbjöd mig ville jag ha en metod som lät mig arbeta induktivt för att ge handledarnas berättelser utrymme. Valet föll på tematisk analys som är 
en kvalitativ analysmetod beskriven av bland andra Boyatzis (1984), Braun och Clarke (2006) och Roulston (2001).

\section{Tematisk analys}

Tematisk analys är ett sätt att se något som inte är uppenbart för andra (Boyatzis, 1998 s. 4). Det är ett ofta använt sätt att rapportera kvalitativa data bland annat inom litteratur, psykologi, sociologi, antropologi, historia, ekonomi och inom naturvetenskap. Trots att det är ett vanligt förekommande sätt att analysera data skriver Boyatzis (1998) och Braun och Clarke (2006) att det är en dåligt beskriven metod där det saknas en tydlig överenskommelse om hur metoden ska användas. Tematisk analys är ett sätt att identifiera, analysera och rapportera mönster i data (Braun \& Clarke, 2006). Medan Boyatzis (1984) skriver att tematisk analys i sig inte är en forskningsmetod utan ett verktyg inom olika metodologier skriver Braun och Clarke (2006) att det är en metod som kan stå för sig själv. Det finns tydliga likheter mellan exempelvis Grounded theory och tematisk analys men tematisk analys går inte hela vägen och producerar en teori (Braun \& Clarke, 2006).

Här använder jag tematisk analys som en realistisk metod för att rapporterar upplevelser, mening och verklighet så som deltagarna i praktiken ser den.

\section{Tillvägagångssätt}

Vid en tematisk analys kan forskaren välja att ge en rik beskrivning av all insamlad data eller en mer detaljerad bild av några få aspekter av den (Boyatzis, 2006; Braun \& Clarke, 2006). Här har jag valt att välja ut några av de områden som berördes under intervjun. Ett område som föll bort vid analysen var till exempel gymnasieskolans påverkan på APL. Svaren förhöll sig väldigt lika varandra och informanterna hade inga djupare åsikter om exempelvis APL-uppgifter. Vid analysen har jag valt att tolka vad informanterna säger och alltså gått bortanför en bokstavlig nivå. 
Tabell 1: Faserna i en tematisk analys enligt Braun \& Clarke (2006 s. 87)

\begin{tabular}{|r|l|l|}
\hline 1 & $\begin{array}{l}\text { Bekanta sig med } \\
\text { materialet }\end{array}$ & $\begin{array}{l}\text { Transkribering, läsa, läsa om och notera } \\
\text { idéer. }\end{array}$ \\
\hline 2 & $\begin{array}{l}\text { Skapa initiala } \\
\text { koderna }\end{array}$ & $\begin{array}{l}\text { Koda intressanta egenskaper } \\
\text { systematiskt, sammanställa relevant data } \\
\text { för varje kod. }\end{array}$ \\
\hline 3 & Leta efter teman & $\begin{array}{l}\text { Sammanställa koder i potentiella teman } \\
\text { och samla all data som är relevant för det } \\
\text { temat. }\end{array}$ \\
\hline 5 & $\begin{array}{l}\text { Definiera och } \\
\text { namnge teman }\end{array}$ & $\begin{array}{l}\text { Jämföra om teman fungerar i relation till } \\
\text { koder och rådata. Generera en tematisk } \\
\text { karta av analysen. }\end{array}$ \\
\hline 6 & $\begin{array}{l}\text { Förfina det specifika med varje tema och } \\
\text { den övergripande berättelsen som } \\
\text { analysen ska berätta. Skapa klara } \\
\text { definitioner och namn för varje tema. }\end{array}$ \\
\hline Skriva en rapport & $\begin{array}{l}\text { Sista tillfället för analys. Välja ut citat för att } \\
\text { illustrera teman och relatera tillbaka till } \\
\text { forskningsfrågorna och litteraturen. }\end{array}$ \\
\hline
\end{tabular}

Med 20 transkriberade intervjuer läste jag under fas 1 igenom materialet och förde anteckningar kring idéer om vad som var intressant. Eftersom jag själv transkriberat mitt material så hade jag redan vid inledningen en djupare förståelse för materialet. Transkribering ska räknas som en tolkande handling då man avgör på vilken nivå transkriberingen ska ske (Lapadat \& Lindsay, 1999). Här föll valet på att skriva det uttalade ordet för att sedan lyssna av intervjun och kontrolläsa texten.

Vid inledningen av fas 2 hade jag en lista med idéer på teman som fanns i mina data och vad som kunde vara intressant. Då ett särdrag i data identifierades antecknades koder i kanten medan materialet lästes igenom. Koderna som producerades här var på både en semantisk och latent nivå. Jag höll mig så nära råmaterialet som möjligt när jag kodade i denna fas. Under fas 2 arbetade jag mig igenom hela materialet och gav lika stor uppmärksamhet till varje detalj för att kunna identifiera intressanta delar och aspekter som senare kunde komma att bilda teman. All kodning skedde manuellt. Tankekartor användes för att lista och knyta samman koder och segment. Här kodades för så många möjliga teman som möjligt från början och sammanhanget runt det intressanta behölls för att hålla kvar betydelsen (Braun \& Clarke, 2006). I denna fas kan varje dataextrakt placeras i så många olika teman som det passar in. Det fanns under den 
här fasen motsättningar inom varje tema vilket ledde till många tankar och sorteringsmönster.

Fas 3 började när all data var kodad. Här hade jag klippt isär alla intervjuer med kodsegment för att samordna dem i teman för att kunna sortera och jämför innehållet i koderna med varandra. Än en gång skrev jag upp koderna på papper och flyttade runt dem för att se hur mönster kunde bildas. Här bearbetades relationen mellan koder, teman och mellan olika nivåer i teman. Vid denna del i processen valdes en del av koderna bort för att fokusera på vad som var viktigt för studiens syfte. Exempelvis föll här teman med fokus på gymnasieskolan bort till förmån för själva handledningen och hur handledarna erbjöd eleverna att delta $i$ verksamheten. I slutet av fasen fanns en samling av potentiella teman och underteman och all data hade kodats i enlighet med dem.

Fas 4 inleddes när tre teman hade arbetats fram. Här arbetades ett tema om (Elevers lärande) till två olika ("Vad handledarna vill lära eleverna" och "Vad de anser att eleverna lär"). För att avgöra om ett tema verkligen skulle vara ett tema i redovisningen använde jag en modell för att avgöra den interna och externa homogeniteten i temat (Braun \& Clarke, 2006).

I fas 5 förfinades och definierades alla teman för att hitta det mest kärnfulla i varje tema. Analysen innehåller en berättelse som varje tema berättar samt en förklaring till hur dessa hänger ihop med varandra. Flera av temana fick här subteman som gav hjälp till att ge struktur till eller visa på hierarkier inom stora eller/och komplexa teman. Temana bygger på mina tolkningar av vad handledarna säger. Samma handledare kan till exempel uppge att de har flera olika skäl till att vara handledare och att de handleder på flera olika sätt och kan därför finnas i olika teman. Det sista steget i fas 5 var att namnge varje tema och subtema.

De citat som valdes ut gjordes så för att det representerar antingen det typiska svaret som på ett bra sätt sammanfattar vad många har sagt eller är speciella i sin form och belyser någon del i resonemanget på ett tydligt sätt. När Hanna får sammanfatta hur eleverna bli mottagna första dagen på APL-perioden (s. 64) finns hennes röst med för att hon kortfattat beskriver vad alla handledare talar om. När Karin säger att hon under dagen kan förklara saker för eleven och själv upptäcker att det hon gör och tidigare i intervjun inte pratat om som handledning finns citatet med för att det på ett kärnfullt sätt belyser ett område som andra talar om men inte i så direkta ord (s. 66).

Eftersom en intention med mitt arbete är att knyta APL-platsen och gymnasieskolan närmare varandra har jag under arbetets gång vid flera olika tillfällen presenterat preliminära resultat för handledare, lärare och APL-ansvariga på BF och andra gymnasieprogram. Särskilt möten med handledare och BF-lärare och deras frågor och kommentarer har hjälpt 
mig att se mina data med andra ögon och vilka slutsatser som kan dras av dem.

\section{Fallgropar i tematisk analys}

I tematisk analys finns det olika fallgropar som forskaren bör undvika (Boyatzis, 1998; Braun \& Clarke, 2006). Projektion, att vara för familjär med data och att verkligen analysera och inte bara sortera data är exempel på vad som bör undvikas. Projektion är när forskaren läser in sin egen känsla, värdering eller attityd i det någon säger. Risken att projicera är större om forskaren är alltför familjär med den miljö som han eller hon undersöker. För att undvika detta har jag utvecklat entydiga koder och varit konsekvent under analysarbetet. Risken för familjaritet är överhängande när man som jag har god kännedom om fältet jag undersöker. Viss familjaritet är dock bra. Eftersom jag förstår språket hos de jag intervjuar, men utan att för den skull fylla i vad informanterna (inte) säger, har samtalet ofta flutit väldigt bra. Genom att aktivt förhålla mig naiv vid mötet med mina informanter tror jag mig ha undkommit denna fallgrop. Ett annat sätt att undvika projektion är enligt Boyatzis (1998) att forskaren bör ta hjälp av andra med att koda informationen och eventuellt även be informanterna om att verifiera data. Ett sätt har för mig varit att genom konferenser och handledarutbildningar komma ut till handledare och APLansvariga och på så sätt har deras igenkännande verifierat mina resultat.

Vidare påpekar Boyatzis (1998) att det är viktigt att komma ihåg att kvalitativ forskning är subjektiv. Att utföra en tematisk analys kräver att man har fokus på vad man gör, och har klart för sig hur varje kod och tema ska tolkas, och är därför tröttsam att genomföra.

\section{Metoddiskussion}

Hade jag kunnat närma mig problemet med yrkeslärande och handledning på förskolor på annat sätt än genom intervjuer? Ja visst! Intervjuerna ger den begränsningen att jag bara kan uttala mig om och analysera vad handledarna har valt att berätta för mig vid det tillfället vi träffades. Det de valt att inte berätta, eller inte kommit ihåg vid intervjuerna, kommer inte fram. Jag hade kunnat komma åt mer om hur handledning faktiskt går till genom att anta ett mer etnografiskt tillvägagångssätt och följa några av mina handledare i deras uppdrag. Nackdelen hade varit att jag fått följa färre handledare. Inom ramen för en licentiatuppsats ansåg jag också tiden vara allt för knapp för detta. För att få en så bred bild av handledning som möjligt och för att låta handledarna komma till tals valdes intervju som metod.

En tanke som jag bar med mig genom hela intervjuperioden var att jag, med min roll som lärare på BF och med bakgrund som förskollärare, skulle 
kunna uppfattas som att jag var ute efter att kontrollera handledarna och deras verksamhet. Genom att alltid förhålla mig intresserad och imponerad av verksamheten som jag mötte, betona hur värdefulla de är för eleverna, mig som lärare och för utbildningen som helhet och hålla mig till ämnet för studien försökte jag undvika detta.

Hur positiv upplevelse intervjun än kan vara för både informant och forskare kan man aldrig bortse från att det råder en maktosymmetri dem emellan (Kvale \& Brinkmann, 2009). I min studie har alla intervjuer varit av en gemytlig typ där samtalet har skett i ett personalrum eller i ett samtalsrum på informantens arbetsplats (eller i direkt anslutning till denna). Det har dock varit upp till mig att ställer frågorna och föra samtalet tillbaka till mitt forskningsområde när jag känt att samtalet har hamnat utanför fokusområdet. Jag har även haft tolkningsföreträde till det som sagts under intervjun.

\section{Etiska ställningstaganden}

De forskningsetiska principer som jag lutar mig mot är de som Vetenskapsrådet (2002) tar upp i Forskningsetiska principer inom humanistisk-samhällsvetenskaplig forskning. Där betonas att det måste finnas en balans mellan samhällets behov av att bedriva forskning och individens krav på skydd. De krav som forskare ska leva upp till benämns informationskravet, samtyckeskravet, konfidentialitetskravet och nyttjandekravet. För mig har detta inneburit att jag har försökt vara tydlig och vid varje kontakt informerat om vem jag är, vad syftet med studien är och hur materialet skulle användas. Jag har vid alla kontakter nöjt mig med muntliga överenskommelser och samtycke och inte begärt skriftligt samtycke till deltagande. Jag har i mitt material redigerat bort namn på ort, förskola, chefer och annat som kan leda till att den enskilda deltagaren kan identifieras. I mina transkriptioner och citat har jag även avlägsnat sådan information som uppenbart och direkt skulle kunna avslöja vilken handledare/förskola citatet härrör från. Förutom dessa etiska frågor tar Kvale och Brinkmann (2009) upp frågor om risk föreligger för terapeutiska relationer mellan forskare och informant. Det fanns informanterna som ville använda intervjutillfället för att få bekräftelse på att det som de gjorde var "rätt" och "bra". Jag försökte alltid förhålla mig mycket imponerad av den förskoleverksamhet som de beskrev för att vinna deras förtroende och respekt. Jag lät de som behövde det vara kritisk gentemot chefer, APLansvariga och lärare och höll med om att så som de beskrev borde det inte vara. Men med ett syfte att lyfta fram deras handlingar som handledare kunde jag styra samtalet i den riktningen när jag kände att så behövdes. 


\section{Kvalitetsaspekter}

Kvalitet i kvalitativa studier kan handla om flera olika saker. Kvalité i form av framställningen som helhet, kvaliteter i resultaten samt validitetskriterier är delar som Larsson (2005) lyfter fram som centrala. För att avgöra om en studie ska betraktas som trovärdig gäller att det råder en harmoni mellan studiens frågor, metod, empiri och slutsatser samt att dessa är noggrant redovisade (Larsson, 2005).

Enligt Larsson (2005) är det viktigt för studiens kvalité att forskaren redovisar och är medveten om sin förförståelse och vilken påverkan den har på studien. Genom att redovisa den förförståelse som min bakgrund som förskollärare samt gymnasielärare har inneburit samt de teoretiska perspektiv och antaganden som ligger till grund för studien ska de bakomliggande perspektiven bli synliga. Som en del av förförståelse ska även den forskningsöversikt som gjordes i inledningen av arbetet beaktas. Även valet av teori kommer att spegla vad som blir viktigt och vad som kommer att ges plats åt i studien. Valet av sociokulturellt perspektiv har lett till att fokus riktats mot hur handledarna ger eleverna tillgång till praktikgemenskapen och hur de tänker kring nykomlingarnas deltagande.

Det som Larsson (2005) framhåller som tecken på kvalité i en kvalitativ studies är om den har god innebördsrikedom, har en god struktur samt är användbar för den egna praktiken. Genom att välja ut citat som ska visa på och underbygga analysen vill jag visa vilket innehåll som ligger till grund för analysen och även de motsättningar och spänningar som finns inom teman. Den analysmodell som jag har inspirerats av bidrog till att skapa struktur på den insamlade materialet. Handledarnas utsagor fick utgöra grundstomme tillsammans med forskningsfrågorna vid redovisningen av resultaten som sedan tolkades med hjälp av begrepp kopplade till situerat lärande. Det är min förhoppning att arbetet ska bidra till diskussion och utveckling inom så väl ämnet handledare/handledning för gymnasieskolan som yrkesutbildning i stort.

När Larsson (2005) diskuterar studiers validitet pekar han bland annat på att ett värde är om studien kan belysa verkligheten på ett nytt sätt. Detta, tillsammans med ett pragmatiskt synsätt där det centrala är om studien har ett värde för praktikern och bidrar till att utveckla verksamheten, blir då ett tecken validitet. När denna studie riktar fokus mot ett sällan studerat fenomen, den handledning som handledare på arbetsplatser genomför inom ramen för en yrkesutbildning, kan den ge en ny bild av verkligheten.

\section{Generaliserbarhet}

I vilken mån slutsatser som dras i denna studie kan användas i andra sammanhang är en relevant fråga för en fallstudie av detta slag. Jag har i 
detta fall använt mig av ett tillgänglighetsurval och intervjuade de första 20 personerna som tackade jag till att vara med i min studie. Genom att uppsöka så många som 20 informanter anser jag att jag har försökt maximera variationen bland handledare i förskolan (Larsson, 2009)

Går det att generalisera resultaten i denna studie bortom yrkeslärande på förskolan? Informanterna i denna studie kan alla ses som pedagoger vilket inte är fallet för alla handledare som tar emot elever från gymnasieskolan (Höghielm, 2005). Det är i många fall läsaren själv som bäst kan avgöra om en annan kontext är nog lika för att generalisera till (Larsson, 2009). Om läsaren känner igen mönstret i de problem som diskuteras och den handledning som beskrivs och därigenom kan dra egna lärdomar om problem och möjligheter med handledning och yrkeslärande på arbetsplatsen vill jag mena att ett visst generellt värde med studien har nåtts. 


\section{Resultat}

I detta kapitel redovisar jag de resultat som har framkommit i analysen av intervjuerna. Kapitlet är upplagt så att varje forskningsfråga kommer att besvaras under ett eget avsnitt.

Det första avsnittet handlar om varför handledarna väljer att fungera som handledare. Det andra avsnittet behandlar vad handledarna anser att eleverna lär under APL och kapitlet avslutas med det längsta avsnittet om hur handledarna organiserar och agerar för att främja detta lärande.

När handledarna uttalar sig om läroplanen är det värt att notera att det är läroplanen för förskolan (Skolverket 1998/2010) som de avser, inte gymnasieskolans läroplan, Gy11, som utgör gymnasieelevernas styrdokument.

I tabell 2 ges en översikt över de teman som sedan presenteras i kapitlet. 
Tabell 2: Schematiskt bild av teman som presenteras. Varje forskningsfråga får ett eget resultatavsnitt. Under dem presenteras de underteman som identifierades vid analysen. Vad eleverna lär är uppdelat på två olika underteman, vad handledarna vill att eleverna ska lära, respektive vad eleverna lär enligt handledarna.

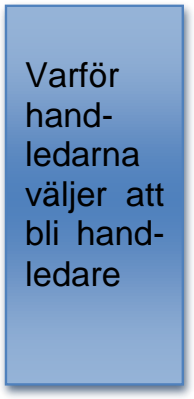

$$
\text { Personligt berikande }
$$

Personlig kunskapsutveckling

Det leder till eftertanke och reflektion

Kan påverka nästa generation

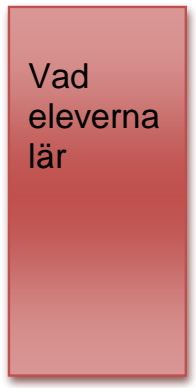
Vad handledarna vill
Det eleverna lär

Social kompetens

Teoritillämpning

Reflektion

Hur

hand-

ledning

går till

Vad handledarna talar om att de gör för att stimulera elevernas lärande

Grundläggande faktorer för lärande

Handledning "på tu man

Handledning "i farten" hand" 


\section{Varför handledarna väljer att bli handledare}

Det finns många anledningar till att personal inom förskolan väljer att ta emot nykomlingar på sin arbetsplats men det finns ändå ett antal typer som framträder som teman i analysen. Skälen som handledarna uppger spänner från att det är personligt berikande, det ger personlig kunskapsutveckling, det ger möjlighet till reflektion och att handledarna vill ta ansvar för kommande generation förskolepersonal. Samma handledare kan uppge flera olika skäl till att ta på sig handledaruppdraget. En anledning som handledarna uppger är att de vill vara med och utbilda blivande kollegor.

\section{Det är personligt berikande}

Det som identifieras som det första temat är att det är personligt berikande. Det som här tolkas som personligt berikande är när handledarna uppger argument som att det är roligt, utvecklande och stimulerande för dem att fungera som handledare. Det framkommer i intervjuerna att detta är ett viktigt argument för att vara handledare. De uttrycker att det ger mycket tillbaka att fungera som handledare. Det är ett extraarbete som belönas genom att de utvecklas som person menar handledare. Att det är roligt att vara handledare får Ellinor och Vivianne exemplifiera.

Jag tycker att det är roligt allså att få hjälpa dem, jag tycker att det är utvecklande för mig också. Sen tycker jag att det är roligt med arbetsuppgifter, jag tycker att det är roligt med folk, jag tycker det tillför mitt jobb. (Ellinor)

Det var roligt, eller det var stimulerande, att träffa unga människor, att få visa vad vi gör. (Vivianne)

Förutom att vara personligt berikande på detta sätt menar en del handledare att nykomlingarnas närvaro och deltagande i verksamheten leder till personlig kunskapsutveckling.

\section{Det ger personlig kunskapsutveckling}

Ett andra tema blir handledarnas uttryck om att de genom att ha elev kommer i kontakt med ny yrkeskunskap eller att de friskar upp vad de en gång har lärt. Handledarna pratar om att de kan bli uppmärksammade på ny litteratur eller exempelvis nya skapandetekniker när gymnasieeleverna kommer till arbetsplatsen. Genom att eleven har varit på praktik i andra verksamheter (exempelvis fritidshem, andra förskolor och dylikt) kan eleven bidra med kunskap om att aktiviteter kan utföras på ett annat, för personalen, nytt och ibland enklare eller bättre sätt. Rebecka och Ellinor menar att: 
Dels så är det lärorikt att man får friska upp gamla kunskaper som kanske har gått och lagt sig lite grann. Och sen så kommer de med nya influenser, ungdomar gör ju det. (Rebecka)

Det är ju utvecklande det här, eftersom jag inte vill, jag har inte kunnat plugga så mycket så det här ger ju, det är ju mycket olika arbetsuppgifter det här ger ju, man får tänka till. (Ellinor)

En del handledare uttalar att de fortbildar sig via elevernas kunskaper. Eleverna kommer utifrån med kunskaper som kan berika praktikgemenskapen (Fuller m.fl., 2005). Då leder det till en professionell utveckling hos personalen som elevernas deltagande bidrar till att synliggöra för handledarna. Fortfarande ligger anledningen till att handledarna valt sitt handledaruppdrag på det personligt stimulerande planet.

\section{Det leder till eftertanke och reflektion}

Ett tredje tema innehåller handledares uttalanden att elevernas deltagande och frågor bidrar till att handledarna själva lyfter sina vardagliga handlingar till reflektion och i högre grad än utan elev problematiserar verksamheten. Elevernas frågor och handledarnas vilja att förklara verksamheten, bidar till att utmana det förgivet tagna i verksamheten. Denna stimulans till reflektion är något som många handledare uppger är en stor vinst med att vara handledare. Att ha elev ger dem en personlig utmaning där de måste reflektera vilket de uppger leder till utveckling i yrket. Gunnel säger exempelvis att:

Man utvecklar sig själv lite också. ... Det är roligt. Man känner att man gör nytta och hjälper till. Samtidigt så får man reflektera mera vad man själv gör. Det ska vi ju göra vare dag men tiden räcker inte till alltid. Man får mer energi när man sitter tillsammans med eleven. (Gunnel)

\section{Kan påverka nästa generation}

Det fjärde temat som identifieras under varför handledarna väljer att vara handledare består av informanternas utsagor om att de genom sin funktion som handledare får chans att påverka nästa generations förskolepersonal medan de ännu är formbara. Alla elever som kommer från BF har inte som slutmål att arbeta inom förskolan, det är alla handledare medvetna om. Ett typsikt uttalande är Rebeckas där hon uttrycker att en elev kan innebära olika mycket arbete men att det kan vara en framtida kollega.

... sen är det så att jag ser en framtid $i$ våra ungdomar och tycker att det är viktigt att de kommer ut. Samtidigt så vet jag att man inte vet vad man får för elev. Det kan vara en som är jätteduktig men det kan också vara ett barn till. Det är både det ena och det andra. Men främst 
att de ska komma och ta över efter oss. Jag tycker att det är jätteviktigt att ungdomarna får komma ut och praktisera och se är det här något för mig eller ... hur är det. (Rebecka)

Handledarna uttrycker sig på två olika sätt i detta tema. Alla handledare beskriver hur de anstränger sig för att visa på att det i förskolan finns ett yrke och en bransch att satsa på. Det finns handledare som önskar och säger att de vill att alla eleverna ska fortsätta inom yrket på ett eller annat sätt. Dessa uttalanden sammanförs under subtemat "Inkastare". Det andra sättet att uttrycka sig är som en del gör och som här identifieras som "Grindvakter" då de uttalar att de är noga med vilka elever de släpper igenom och menar att det är kårens rykte som kan komma på skam om "fel" personer arbetar här. Medan "Inkastarna" har en positiv inställning och uttalar att en bra start kan göra att eleverna inser vilket bra jobb detta är och kommer att vilja jobba med detta i fortsättningen har "Grindvakterna" en lite mer eftertänksam hållning.

"Inkastarna" vill till nästan varje pris att eleverna ska fortsätta inom branschen och de kan arbeta hårt för att övertyga elever om att inte sluta utbildningen eller byta bana. Det finns exempel på handledare som med stolthet i rösten berättade att hon hade övertygat en elev som hade tänkt hoppa av utbildningen att inte göra så. Även om eleverna inte fortsätter med att arbeta med små barn så vill dessa handledare gärna att så många som möjligt ska fortsätta med någon form av barnverksamhet som till exempel fritidspedagog, fritidsledare eller som lärare. I det här subtemat pratar handledarna ibland om eleverna i samma ordalag som de gör om barnen; eleverna är under utveckling och de ska ges möjlighet att växa som individer under praktikperioden. Handledarna har här alla en optimistisk syn på att eleverna kommer att tycka att förskolan är en bransch att satsa på och det är upp till dem som handledare att genom ett gott bemötande visa eleverna detta. Hanna och Tina får illustrerar denna del av temat när de säger att:

Jag tycker att det är viktigt att man får bra människor att jobba inom förskolan och då är det också viktigt att man känner för de här eleverna som kommer och att man får växa, precis som våra små barn inom förskolan. (Hanna)

Det är kul att möta ungdomarna och föra yrket vidare. Det är inte alla som vill göra det här så det är viktigt att vi får in folk och bra folk. (Tina)

De handledare som är lite mer kritiska i sitt förhållningssätt till om de vill rekommendera alla elever att fortsätta utbilda sig och arbeta inom förskolan kan uttrycka att de vill att eleverna ska ha en realistisk syn på vad som kommer att krävas av dem och vill att eleverna ska visa dessa kvalitéer under utbildningen. I subtemat "Inkastare" finns handledare som 
säger att de kan be eleverna fundera på om de verkligen vill jobba inom förskolan och om de inte verkligen är beredda att satsa på yrket bör de kanske fundera på att göra något annat.

Och vi har faktiskt haft elever som varit, som har velat komma tillbaka men vi har sagt nej tack vi gör inte det den här gången. (Marianne)

Det finns handledare i subtemat "Grindvakter" som talar om att de sätter sitt eget rykte som yrkeskunniga på spel med att ha elev. Om eleven efter utbildningen kommer ut till en kollega och inte har de kunskaper som hon tyckte att en barnskötare ska ha kan det falla tillbaka på att hon som handledare gjort ett dåligt jobb.

Men sen måste jag ju också tänka på studenten det kanske är mina kommande kollegor. Vad förväntar jag mig av mina kollegor, jo då måste man ju ... på ett visst sätt. De måste sättas in i uppgifterna för sen kommer de ut och liksom kanske som vikarie och då måste de kunna vissa saker. (Patricia)

Patricias uttalande är ett exempel på att det är viktigt för handledarna att eleverna efter APL-periodens slut är insatt i arbetet på förskolan. Det handlar ofta om att handledarna ser brister i elevernas engagemang i arbetet som leder till att de är tveksamma till elevernas framtid i branschen.

Även "Grindvakterna" är beredda att jobba hårt för att stötta de elever som uttalar att de vill lära sig yrket.

När man har haft dom under ett antal veckor då kan man se en jätteskillnad från första, andra, tredje dan till slutet på perioden. Och då känner man att här, här är det en som vill jobba med barngrupp och som tar till sig. Då försöker jag hela tiden, titta på de är sångerna, skriv ner dom eller ta kopior för att det är kommer du behöva sen någon gång. (Nina)

Handledarna har i båda fallen det gemensamt att arbetet med barn är ett så pass viktigt yrke att man inte ska göra det om man inte verkligen vill. Bakom båda dessa gruppers uttalanden finner jag en stark yrkesstolthet. Trots att det är ett lågavlönat yrke med låg status så ger det så mycket tillbaka att arbeta med barn att de vill rekommendera det till den som är, ibland bara lite, intresserad. Dessa uttalanden tolkas som att handledarna tar ett övergripande ansvar för verksamheten när de ser som sitt uppdrag att fungera som ställföreträdande arbetsgivare. I valet att vara handledare lägger de ett ansvar att vara med och forma sina blivande kollegor.

Eftersom många av handledarna har haft uppdraget under många år tolkas det som att det är ett belönande uppdrag. Det utgår ingen ersättning 
för handledaruppdraget, vare sig personlig eller till enheten där de arbetar, utan sker helt på frivillig bas. Elever kan vara duktiga och näst intill en kollega och ibland ta mer tid än ett barn om de behöver mycket stöttning, inte kommer till arbetsplatsen eller har stora problem. Varje ny elev innebär både möjligheter och en risk och är något varje handledare är medveten om. Att introducera en nykomling i yrket är trots det givande på många plan.

Det finns alltså fördelar både på det personliga och organisatoriska planet $i$ att ha en elev. Det ligger en personlig belöning i att ta sig an en elev samtidigt som det stimulerar till eftertanke och reflektion som är en del av yrket. Att handledarna lär sig mer om sitt yrke genom att ha elev är uppenbart. Att det dessutom finns fördelar för förskolan och verksamheten som helhet när man låter elever vara en del av den är också tydligt.

\section{Vad eleverna lär under APL ur handledarnas perspektiv}

När den andra forskningsfrågan som handlar om vad vilka kunskaper handledarna anser att eleverna bör lära sig och lär sig analyserades framkom två huvudteman. Det första temat är "Generella arbetslivskunskaper" och det andra "Specifika yrkeskunskaper". Det är således handledarnas utsagor om vad deltagandet i verksamheten (Wenger, 1998) ger eleverna för relevanta kunskaper. När handledarna talar om elevernas lärande gör de så ur två synvinklar, dels vad de vill att eleverna ska lära och dels vad de tror att eleverna lär under APL och analysen delas därför upp på detta sätt.

Under temat "Generella arbetslivskunskaper" samlas handledarnas uttalanden om det som här tolkas som viktiga förmågor på alla arbetsplatser oavsett yrke eller bransch. Exempelvis rör sig detta om att komma i tid och hur man ska uppföra sig på en arbetsplats. Temat "Specifika yrkeskunskaper" blir här de kunskaper och färdigheter som handledarna uttalar att eleverna behöver för att arbeta inom förskolan. Exempel på dessa specifika yrkeskunskaper som handledarna talar om är med mina ord social kompetens i form av god kommunikationsförmåga, en förmåga att omsätta teori till praktik och att använda reflektion för utveckling.

\section{Vad handledarna vill att eleverna ska lära - Generella arbetslivskunskaper}

När handledarna talar om vad de vill att eleverna ska lära sig som här faller in under temat "Generella arbetslivskunskaper" talar de om olika saker. Bland annat att talar de om att det är viktigt att komma i tid till arbetet som 
viktigt att lära eleverna. Att komma i tid är ett sätta att visa respekt, det är något som man ska veta att man gör och handledarna talar om att det ligger som en grund för vad det innebär att ha ett arbete. Mariannes uttalande om vad som är viktigt att lära är ett typiskt exempel när handledarna talar om vad som är viktigt för eleverna att förstå.

Jag är väldigt noga med tider, det är $\mathrm{A}$ och $\mathrm{O} \mathrm{i}$ arbetslivet.

(Marianne)

\title{
Vad handledarna vill att eleverna ska lära - Specifika yrkeskunskaper
}

"Specifik yrkeskunskap" är här de kunskaper och färdigheter som handledarna uttrycker att eleverna behöver lära sig för att arbeta som barnskötare. "Specifika yrkeskunskaper" kan synas innehålla disparata delar men har som gemensam nämnare att det är för barnskötaryrket viktiga kompetenser enligt handledarna som det handlar om. Detta tema innehåller tre olika varianter av specifik yrkeskunskap som är att ha en god social kompetens, att kunna tillämpa olika teorietiska modeller samt att reflektera för att utveckla arbetet. En av delarna i social kompetens är bemötande som också går igen under tillämpa teori eftersom en stor del av att omsätta läroplanen handlar om barnsyn och hur man bemöter barn.

Till social kompetens räknas när handledarna talar om att det krävs att man är en glad och trevlig person som har roligt för att arbeta i förskolan. Alla handledare är stolta yrkesmänniskor och vill förmedla det till eleverna. Anna sammanfattar väl resonemanget om att eleverna ska uppleva yrket som roligt och att de ska förstå den teori som ligger till grund för yrket när jag frågar vad hon vill att eleverna ska få vara med om, göra eller lära sig medan de är på förskolan.

\begin{abstract}
Alltså, det är ju hela arbetet hur man tänker och så. Allting läroplan och allting, jag vill att vi ska ha kul, att det ska vara roligt. Alltså det ska vara en rolig upplevelse och att de ska känna sig behövda och att de, jag tycker att det är viktigt att de ska känna att de är en av oss på något sätt att man inte... För en del elever vet jag har sagt att man făr nästan ont va, man får bara klippa papper eller bli utnyttjade på ett sätt som jag tycker är. (Anna)
\end{abstract}

När handledarna talar om det som här samlas under social kompetens handlar det om att handledarna vill att eleverna ska lära sig specifika yrkesrelaterade förmågor som till exempel att utveckla god förmåga att kommunicera med olika människor. Handledarna uttrycker att yrket innehåller många möten med både barn och vuxna och det är viktigt att kunna bemöta både barn, föräldrar, chefer och stödpersonal. Att barnen idag kommer från många olika kulturer har också gett bemötande nya 
dimensioner de senaste åren. Ett exempel på konkret social kompetens som handledarna tar upp som är viktig är att eleverna lär sig är att de ska kunna presentera sig för föräldrar som de kommer i kontakt med under praktikperioden. Att möta föräldrar är en del i arbetet med barn.

Yrkesrollen är ett professionellt bemötande gentemot kollegor,
föräldrar och barn eller tvärtom i ordning oj, då. Som är viktigt hur jag
bemöter, att man bemöter på olika sätt. Hur man bemöter. Hur jag ser
på barnen, hur jag behandlar barnen hur jag behandlar alla
föräldrarna, för alla föräldrar är olika. De måste jag också träna in, hur
bemöter jag, jag får inte lysa igenom // ... // Det brukar jag också prata
om att om jag kommer cyklandes till jobbet och tänker på allt möjligt,
så ser jag en förälder med barn och då blir det (skiner upp i ett stort
leende). Då kommer leendet på läpparna och så ropar man hej, och
man går in i den rollen oberoende av tankarna på väg till jobbet. (Fia)

Vikten för eleverna att förstå att social kompetens är viktigt betonar en handledare när hon säger att:

Många vikarier, när det kommer direkt från Barn- och fritid är ganska ovetande om hur det är att vara vikarie. Egentligen skulle man ha någon slags checklista eller handledning för hur ska jag bete mig den första tiden som jag kommer ut som personal. Bara det här att gå fram och hälsa på föräldrar, hej, jag heter Stina och jag vickar här idag. Det är väldigt få vikarier som gör det idag. (Jenny)

Enligt handledarna behöver eleverna göra för att lära social kompetens. De behöver få se hur handledaren gör, de behöver själva prova på för att växa in i rollen och senare självständigt kunna ta ansvar för att till exempelvis bemöta föräldrar. Vägen mot att bli fullvärdig medlem i praktikgemenskapen är lång och det är mycket som ska läras (Lave \& Wenger, 1991; Wenger, 1998).

Handledarna talar om att de vill ge eleverna möjligheter att kunna tillämpa olika teorietiska modeller och knyta ihop det som de läser i skolan med den verksamhet som de möter på arbetsplatsen. Det som identifieras som teoritillämpning handlar om olika teorier som ska omsättas till verksamhet i förskolan. Teori finns i det här sammanhanget i form av utvecklingspsykologi, läroplanen och olika pedagogiska tankelinjer att följa. Till exempel vill handledarna att eleverna ska lära sig hur olika barn kan vara fast de är lika gamla. Handledarna vill att eleverna ska få möjlighet att upptäcka variationer och avvikelser från teoretiska förutsägelser. Cecilia beskriver hur hon tänker kring vad som passar att läsa i skolan och hur hon vill att eleverna ska tänka kring teorier under praktiken. 
Det är ju teorier kring barn. Utveckling, barns utveckling, det är sånt som man måste läsa och sedan måste man förstå och sedan måste man kunna tänka att alla barn är olika. Ofta tänker man att alla barn är så där som det står, men så är det ju inte. (Cecilia)

Som en variation av vad handledarna vill att eleverna ska lära som är en del av teoritillämpning finns även att konkretisera läroplanen. Läroplanen kan ses som ett teoretiskt ramverk och rättesnöre på vilken personalen bygger verksamheten och här ses den som en för praktikgemenskapen viktig artefakt (Wenger, 1998). Att lära sig att göra verksamhet av detta teorietiska ramverk och det konkreta handlaget i att arbeta med barngrupp är viktigt för handledarna och något som de vill att eleverna ska lära. Det handlar om att kunna läroplanen, att förstå den och att omsätta den till praktisk verksamhet. En del handledare säger rakt ut att de vill att eleverna ska lära sig om läroplanen under praktikperioden. Det räcker inte enligt handledarna att kunna detta på ett abstrakt plan. Ett exempel på att omsätta läroplan till verksamhet är när handledare uttrycker att de vill att elever ska förstå att man ska göra pedagogik av vardagen som till exempel vid blöjbyte på ett barn.

Teoriomsättning med anknytning till läroplanen blir här även när handledarna pratar om att de vill lära eleverna vilken barnsyn som läroplanen ger uttryck för. Att det här handlar mer om teori än bara social kompetens visar exempelvis Davids uttalande. Bemötande handlar om att göra på ett visst sätt som bygger på en teorigrund. Att det är en viktig del i yrket att kunna bemöta olika människor i olika situationer är ett återkommande uttalande från handledare.

Det är hur man är mot barnen, alltså, inte att de kan måla eller snickra
eller vad som helst utan vilket förhållningssätt man har mot barn. Vår
värdegrund, det är det absolut viktigaste. Hur man löser konflikter, hur
man utmanar dem, hur man får dem nyfikna. (David)

De ska få vara med och se hur man bygger en verksamhet för barn, där barnen är i centrum och får möjlighet att växa och bli så bra som de kan. Se hur man tar tillvara barns fantastiska skaparglädje och hur man stöttar dem. (Lena)

Den tredje variationen av vad handledarna önskar att eleverna lär på APL blir här att lära sig reflektion. Den innehåller handledarnas uttalanden om att de vill att eleverna ska lära sig tänka kring verksamheten, vad de gör och varför. När handledarna pratar om denna reflektion handlar det dels om att reflektera om verksamheten och läroplanen och dels om att reflektera kring utvecklingspsykologiska antaganden. Detta får Hanna illustrera när hon säger att: 


\begin{abstract}
Vardagen är viktig överallt och då är den viktig för den som är elev att upptäcka saker och inte känna att ja ha nu har den här dagen gått och utan man har fått så mycket ändå en vanlig vardag. Små saker, stanna upp och tänk efter. Så det uppmanar jag alla elever att det är något viktigt man ska ha med sig från utbildningen och in i förskolan. Man ska ha med sig att reflektera. Träna på det, öva på det reflektera varandra, eller göra olika saker på utbildningen för att träna på det där med att reflektera. Och små saker också många tycker att det ska vara så jättestort för att komma och berätta för föräldrarna medan det är tvärtom. Vi ska börja längst ner och plocka de här små sakerna.

(Hanna)
\end{abstract}

Den här delen av temat på forskningsfrågan vad handledarna vill lära eleverna på APL har handlat om det specifika yrkeskunnandet som handledarna talar om som viktigt. Det som har identifierats som en röd tråd igenom hela temat är att handledarna först och främst vill att eleverna ska uppleva APL-perioden som rolig och stimulerande och att eleverna lär genom ett aktivt deltagande i verksamheten (Wenger, 1998) De specifika yrkeskunskaperna handlar om yrkesrollen, att vara socialt kompetent i bemötande med människor och att förstå att det finns flera teorier kopplade till verksamheten som alla är länkade i varandra.

När de sedan talar om vad de anser att eleverna lär hamnar fokus mer på generella arbetslivskunskaper.

\title{
Det eleverna lär på APL enligt handledarna - generella arbetslivskunskaper
}

I detta avsnitt kommer jag beskriva det som handledarna talar om att eleverna tar med sig efter APL. Här finns samma uppdelning som i föregående avsnitt i två teman med generella arbetslivskunskaper och specifika yrkeskunskaper. Medan handledarna hade höga tankar om vad de ville lära eleverna ligger deras uttalanden om vad de uppfattar att eleverna lär på en mer basal nivå.

Under temat generella arbetslivskunskaper samlas igen sådan kunskap som att komma i tid och hur man ska uppföra sig, nu med förtecknet att dessa uttalanden handlar om vad handledarna anser att eleverna lär under APL. Det framkommer att dessa generella arbetslivskunskaper är mycket viktiga för handledarna. Det är grunden som eleverna måste lära sig. Utan dessa kunskaper blir det svårt för eleverna att bli accepterade som en fullvärdig medlem i en yrkesgemenskap (Lave \& Wenger, 1991) menar handledarna. Susanne och Patricia menar till exempel att detta är en del av det som eleverna lär under APL då de säger att:

De lär om arbetslivet hur det är, det är viktigt att komma i tid, att vara trevlig mot varandra. (Susanne) 
Det kanske är deras första möte med arbetslivet och se att, hur det är att vara på en arbetsplats. (Patricia)

\title{
Det eleverna lär på APL enligt handledarna - specifik yrkeskompetens
}

När handledarna talar om vad de uppfattar att eleverna lär under APL och talar om specifik yrkeskompetens så framkommer två varianter, social kompetens och teoritillämpning.

Det yrkesspecifika i social kompetens, och som skiljer det från social kompetens som går in under generell arbetslivskunskap, ligger i att arbetet på förskolan karaktäriseras av att det sker i arbetslag där kommunikation är viktig och är relationsinriktat (Ekström, 2007). Handledarna beskriver att det i arbetet på förskolan sker många möten med olika människor, i varierande positioner med olika kulturell bakgrund. Därför är det viktigt att eleverna lär sig att kommunicera och bemöta människor. Exempel på att social kompetens är yrkesspecifik visar sig när handledarna talar om att eleverna lär sig att kommunicera och bemöta i ett yrkesspecifikt sammanhang.

\begin{abstract}
Alltså den sociala kompetensen, här måste du prata. Både med kollegor, barn, föräldrar, det är kommunikation. Och ibland blir det fel, det blir fel med föräldrar också men så är det. Det finns väl inget ställe där vi pratar så mycket som här? (Cecilia)

Jo men framförallt det här med att umgås med andra människor inte bara i sin ålder. Vi är ju nästan, här finns det yngre, sen finns det äldre och sen finns det dessutom barnen. Det är många man ska ta hänsyn till. Det är många som tycker och tänker olika och här ute är det många olika kulturer det är mycket man lär sig på det. (Ingrid)
\end{abstract}

Cecilias exempel visar att lära handlar om att göra och öva. Det kan bli fel men det gör ingenting. Komplexiteten i kommunikationen ligger bland annat i att det är människor från olika kulturer, i olika åldrar och i olika roller som det ingår i yrket att möta.

Teoritillämpning är även en variant som identifieras när handledarna talar om vad de anser att eleverna lär under APL. Det handledarna menar att eleverna lär är här att olika teorier ska bli till konkret verksamhet på förskolan. Det handlar om att eleverna lär sig använda och fördjupa sina kunskaper i bland annat utvecklingsteori och pedagogik. Det handlar i stort om att få en dag på förskolan att fungera enligt intentioner i styrdokumenten för verksamheten, Lpfö98/10. Här pratar handledarna om att eleverna lär sig att omsätta läroplanen från ett ibland svårt språk till verksamhet för små barn. Förutom läroplanen som teori menar även handledarna att eleverna lär sig att omsätta pedagogiska och psykologiska teorier till verksamhet. Att göra verksamhet på detta sätt 
handlar enligt handledarna om att få detta raster av teoretiska ramverk att samspela med barngruppen. Det kan vara att få rutiner att fungera, genomföra planerade aktiviteter som passar barnens utvecklingsnivå och att se till att det blir roligt för barnen på förskolan.

Några exempel på hur handledare talar om att eleverna lär sig använda olika teorier är när Susanne, Fia och Nina säger att:

De lär sig omsätta läroplanen, de lär hur man bemöter barn och föräldrar. (Susanne)

... att känna att man kan koppla det man läser, att göra en utvärdering. Ja men vi läste det här, vad det nu är, är det så i verkligheten? Stämmer det? Nej, så är det inte riktigt. Verkligheten ser inte riktigt ut som de säger. Eller, det här stämmer, det är verkligen de här stegen $\mathrm{i}$ utvecklingen i ord, meningsbyggnad (Fia)

Jo men det är väl det här med barns omvårdnad, det här att en treåring eller en tvååring behöver det här för att kunna utvecklas på ett bra sätt. Här jobbar vi ju utifrån det, praktiskt, men i skolan läser man det. Psykologi och såna saker, pedagogik och alltihopa det här och då får man liksom båda sidorna, både den praktiska och den teoretiska. (Nina)

När Anna talar om vad hon anser att eleverna lär under APL kan det stå som ett exempel på att teorin kring barn och arbetet i barngrupp har en stark koppling till varandra.
Ja men det är det här med ... hur man tar barn när det uppstår konflikter till exempel. Det kan du läsa om hur du ska göra men hur man ska göra kan man inte alltid göra det funkar inte i praktiken. Barn som är ilskna till exempel som trilskas, hur ska man få dem att vara medgörliga? Såna saker är det ju. Tyvärr så är det lite konflikter, barn emellan och... när det är så många barn på så liten yta. Att lära sig hur det är och så. Att dela upp barnen, att alla behöver inte vara på samma ställe. Nu tar jag de här tre och gör det här så kan de tre göra det där så blir det lite lugnt där ett tag om det nu är så att alla inte funkar tillsammans. Ta hand om barn som är blyga till exempel. Hur tar man hand om de när man inte får något svar till exempel. Det kan man inte läsa sig till det har med erfarenhet att göra. (Anna)

Det finns alltså likheter mellan hur handledarna talar om vad de vill att eleverna ska lära och vad de slutligen tror att eleverna lär under APL. Det finns en nivåskillnad på så sätt att medan handledarna vill lära eleverna att reflektera så är det inte något som de talar om att de tror att eleverna lär sig. Att handledarna anser att praktiken däremot fungerar som en koppling mellan de teoretiska studierna och den praktiska verkligheten på förskolan framgår tydligt. Vad som också är tydligt i resultaten är att 
handledarna uppfattar läroplanen för förskolan som ett viktigt redskap i arbetet och en central artefakt (Wenger, 1998).

\section{Hur handledning går till}

Den tredje och sista forskningsfrågan är den som här får störst utrymme. Frågan om vad handledarna gör för att eleverna ska komma in i praktikgemenskapen har vid analysen genererat tre olika teman. Det första är Handledning "på tu man hand", det andra Handledning "i farten" och det tredje temat blir Vad handledarna gör för att stimulera elevernas lärande.

När handledarna talar om handledning framkommer det att den genomförs på två olika sätt. Det ena är när handledaren och eleven sitter ner tillsammans i lugn och ro bakom stängd dörr. Denna form av handledning får här namnet "på tu man hand" därför att det alltid handlar om eleven och handledaren och för att det alltid sker på avskild plats. Detta sätt att bedriva handledning liknar starkt det sätt som Lauvås och Handal (2001) benämner Handling och reflektionsmodellen. Det andra sättet är när handledarna under pågående verksamhet berättat eller förklarar något för eleven. Denna form av handledning får här namnet handledning "i farten" och liknar Lauvås och Handals (2001) lärlingsmodell. Det tredje temat är en samling av alla de beskrivningar av vad handledarna gör för att stimulera elevernas lärande som kan definieras som handledning men som inte alltid benämns som handledning av informanterna. Avsnittet inleds med en beskrivning av det som tolkas som grundläggande för handledarnas arbete $\mathrm{i}$ att handleda gymnasieelever.

En grundläggande faktor för att eleverna efter APL ska se en framtid i, och ha möjlighet att lära yrket är enligt handledarna att de upplever att det är roligt. För att skapa en bra miljö för eleverna är handledarna måna om att de ska trivas och känna sig välkomna. Här pratar handledarna om eleverna på ett sätt som påminner om hur de pratar om barnen i barngruppen. Eleverna ska få möjlighet att utvecklas, de ska få ha roligt under APL perioden och de ska helst känna att de vill komma till förskolan med lust att lära varje morgon. Detta påpekar handledarna är grundläggande i deras arbete som handledare. Praktikperioden ska vara jagstärkande för eleven. För att göra eleverna trygga lägger handledarna mycket tid på att få eleverna att känna sig som en i arbetslaget. Det kan bland annat handla om att handledarna ser till att vara tillgängliga de första dagarna eleverna finns på förskolan. Då går de inte iväg på planerade möte eller tar ledigt för att eleven ska känna att de bryr sig om dem och finns där för dem. I uppdraget som handledare menar flera att de räknar med att det ingår att ta sig an eleven även på raster. De kan till exempel bjuda med eleven att komma med på lunchpromenader och dylikt. Att vara 
handledare är ett uppdrag som sträcker sig utanför det egentliga arbetet. En handledare berättade att när hon haft en rullstolsburen elev stannade hon kvar på arbetsplatsen under lunchrasten de första dagarna för att inte lämna eleven ensam.

Man får ge lite av sig själv när man är handledare. Man får bjuda till lite och offra lite av sin rast egentligen. (Anna)

För att göra praktikperioden till en rolig upplevelse på elevernas villkor vill ofta handledarna veta vad som intressera eleverna. För att anpassa APL-perioden till den enskilde eleven och locka fram deras individuella styrkor försöker handledarna hålla sig lyhörda för elevens initiativ och bejaka de idéer som de kommer med. Om eleverna har svårt med att komma med idéer ger handledarna gärna förslag på vad andra elever har gjort och funnit roligt eller vad barnen brukar tycka är kul.

En annan grundläggande faktor som handledarna ger uttryck för är att lärande sker i vardagen. Handledarna menar bestämt att de inte arrangerar lärsituationer för eleverna. De menar istället att det är genom deltagande i de vardagliga arbetsuppgifterna eleverna lär. Lärandet under APL är således situerat (Wenger, 1998). David och Ingrid menar att eleverna har många chanser att lära genom att delta i verksamheten medan de är på praktikplatsen.

\footnotetext{
Alltså under en dag så händer det ju massor med saker så det finns ju massor med tillfällen att se hur vi gör så att säga (David)

Jag: Brukar du försöka lägga fram saker, situationer, nu gör vi så här för att vi har elev, eller är det vardag?

Ingrid: Nej det är nog vardag. Kanske var det så när de var ute en vecka för att de skulle hinna med på många aktiviteter, att vi har skapat en extra aktivitet det vet jag att det har hänt men annars är det vardag för det är ju aktiviteter hela tiden. Nej, det är vardag. (Ingrid)
}

Deltagande i vardagen är centralt och handledarna vill stimulera till ett aktivt deltagande bland annat genom att bygga på elevernas intressen. Det är i denna vardag handledning "i farten" bedrivs. Lärande bygger på ett aktivt deltagande i praktikgemenskapen (Wenger, 1998). När handledarna svara på direkt fråga om handledning är det ofta det som här benämns som handledning "på tu man hand".

Ett tydligt resultat i studien är att handledarna beskriver att det är de som har det yttersta ansvaret för eleverna men att hela arbetslaget är delaktiga i att ta hand om eleven. Detta innebär att det är handledaren som sköter kommunikationen med gymnasieskolan och har ansvar för bedömning och att samtala med eleven om det är något som inte fungerar. 


\section{Handledning "på tu man hand"}

Det som här blir första temat Handledning "på tu man hand" beskriver alla informanter. Den går till så att elev och handledare ibland vid ett, ofta två eller tre, och ibland fler tillfällen, sitter ner för sig själva i ett rum med stängd dörr där de kan prata ostört. Ett vanligt förekommande scenario är att handledaren och eleven sitter ner och pratar på förmiddagen första dagen på elevens praktik. Då handlar det ofta om arbetstider, tystnadsplikt, de uppgifter som gymnasieskolan har skickat med eleven och vilka förväntningar eleven har på sin praktikperiod. Ofta beskriver handledaren även verksamheten och barngrupp och personal presenteras under en rundvandring. I vissa fall kan detta inledande samtal ta upp till några timmar medan det i många fall beskrivs ta ungefär en timme.

Under de efterföljande handledningstillfällena berättade handledarna att samtalet handlar om många olika saker, exempelvis hur eleverna trivdes, om de har kommit in i arbetsgruppen och de uppgifter som eleverna hade med sig från skolan. Uppgifterna från skolan kan handla om faktainsamling, eleven ställer då frågor till handledaren och om exempelvis planering och utvärdering av aktiviteter. Samtalet kunde även kretsa kring elevens beteende i barngruppen och dess konsekvenser för eleven själv, enskilda barn och för barngruppen. I vissa fall kunde elever få enskild handledning på detta sätt upp till en gång per vecka. Tidpunkten för dessa samtal är planerad sedan flera dagar i förväg.

Syftet med dessa handledningstillfällen "på tu man hand" var enligt handledarna att få eleven att känna att handledarna hade tid för dem, att följa upp deras uppgifter från skolan och för att de tillsammans skulle kunna reflektera över det som eleverna hade gjort och varit med om.

Några handledare berättar hur de under dessa samtal ställer frågor till eleverna för att de ska reflektera kring vad som har hänt i barngruppen under en aktivitet. Handledarna berättade att de till exempel kan fråga, Såg du det där som hände? Tänkte du på att...? för att leda in eleverna på de händelser som de vill att de ska uppmärksamma.

Handledarna uttrycker olika åsikter om denna handledning blir lika för alla elever. Några uttrycker att handledningen blir lika eftersom det är liknande uppgifter som de handleder eleverna kring. Andra menar att handledningen blir olika eftersom det är olika elever med olika behov som handleds.

Handledarna beskriver även hur de kan följa upp dessa formella handledningstillfällen med en kortare summering vid slutet av dagen eller veckan då handledarna uttrycker att de vill fånga upp frågor som kan ha dykt upp under arbetet. Formen kan då beskrivas som spontan då handledningen inte är planerad och inte sker bakom stängd dörr men vid ett lugnare tillfälle som en rast eller att handledare och elev kan ha ett kort 
tillfälle för sig själva. Hanna beskriver hur ett samtal första dagen kan gå till och hur hon följer upp det samma dag.

\begin{abstract}
Först introducerar man eleven och vi brukar försöka komma ifrån barngruppen direkt i den mån det går, relativt direkt, första dan i alla fall och berätta lite om våran avdelning och vi går husesyn och lite så här. Lite hur upplägget är överhuvudtaget. Hur vi jobbar och sen så brukar vi gå in, det är ju lite beroende på årskurs och så, men sen så går man ju in och säger att nu är vi här så du får bekanta dig lite med barnen. Man släpper henne eller så.... Sen brukar vi ha en avstämning första dagen och kolla hur det har gått hur hon har upplevt. (Hanna)
\end{abstract}

Många handledare har ett stort förtroende för denna spontana handledning "på tu man hand" för elevernas lärande. Vid direkta frågor om handledning var det oftast denna form av handledning som avsågs. Handledare kan också beskriva att elever säger att de inte behöver enskild handledning. En problematik som ofta nämns är att det kan vara svårt att få tid till denna form av handledning.

\title{
Handledning "i farten"
}

Handledning som den beskrivs i förra temat är det första som handledarna beskriver under intervjuerna. Trots det är handledning "i farten" minst lika vanlig. Det som faller under detta tema är när handledarna talar om att de visar, beskriver, berättar eller förklarar något för eleven under pågående verksamhet. Exempelvis beskriver handledarna denna form av handledning när de talar om att de är handledare från den sekund som eleven kommer in på förskolan. Det kan handla om att handledarna beskriver hur de är lite mer korrekta när de har elev, de är tydligare än vanligt när de pratar med kollegor som är mer insatta i verksamheten. När handledarna exempelvis pratar klart med ett barn innan de låter sig avbrytas av nästa barn kan de förklara för eleven varför de låter det andra barnet vänta och hur de tänker kring sådana situationer. Eftersom förskoleverksamheten inte går att sakta ner, pausa eller stänga av för att förklara eller upprepa något ställer det speciella krav på handledare och elev. Handledaren ska ha fokus på barnen samtidigt som hen bistår eleven. Medan handledare ibland kan förklara något medan verksamheten pågår finns det många situationer där förklaringen behöver tas efteråt utan att barn eller föräldrar finns med.

Även reflektion kan förekomma under dessa korta stunder medan verksamheten pågår. Ett exempel på försök till reflektion under handledning "i farten" är när de pratar om hur de vill få med eleven i hur de tänker. Det kan handla om att handledarna förklarar något som händer, hur de ser på situationen och vad de vill att eleverna ska uppmärksamma i just den stunden. 
För en del handledare är detta den form av handledning som de föredrar eftersom det är så svårt att få till tid för att sitta ner "på tu man hand". För andra är det mer naturligt eftersom de menar att handledning behöver ske medan verksamheten pågår och kan liknas vid deltagande i praktikgemenskaper (Lave, 1991). Ingrid ger exempel på hur hon försöker fånga det som händer och få med eleven i hur hon tänker när hon berättar att:

\begin{abstract}
Då försöker jag fånga ögonblicket när det sker. Alltså om två barn är oense och jag går in och agerar och vägleder barnen in i en annan situation då kan jag säga, såg du hur jag gjorde nu?, till eleven. Så kan man göra när två barn är oense, då bli det lite nyfikna. Jag kan säga såg du Kalle och Linus hur de gjorde nu, de lekte jättebra där med klotsarna, såg du det? Göra dem uppmärksamma på vad som händer och att jag är vaken också och kolla nu Stina och Lisa, titta vad bra det går? Eller tvärt om, Nu måste jag gå in och agera, ser du varför? Alltså försöka få med eleven i tänket, alltså varför går jag in och agerar där. (Ingrid)
\end{abstract}

Ingrids uttalande kan även illustrera att handledning "i farten" sällan sker medan något händer utan precis efter att något har skett. De handledare som säger att denna form av handledning inte fungerar speciellt bra uppger bland annat att det kan handla om att barn idag inte accepterar att vuxna inte ska bli avbrutna utan vill ha uppmärksamhet direkt. Susanne får illustrera problematiken kring att handleda mitt under pågående verksamhet.

Jag kan inte förklara varför jag inte "hör" vad Olle säger framför Olle men jag brukar skynda mig för att komma ihåg att förklara för det kan verka konstigt att jag inte hör Olle men jag höll ju faktiskt på med Johannas skor och Olle han ska jämt ha sin vilja fram direkt så vi har pratat ihop oss om att för det är så lätt att bara släppa det man har och göra det han vill när han säger till fast man höll på med något annat. Sen när vi är klar med det, då kan Olle få hjälp men han behöver vänta på sin tur. (Susanne)

Både handledning "på tu man hand" och "i farten" förekommer parallellt hos de flesta informanterna. Även bland de som inte uttalat säger sig syssla med handledning "i farten" beskriver att medan verksamheten pågår fungerar de som stöd för elevernas lärande. Viviannes uttalande är typiskt. Handledning är när de sitter ner tillsammans, vilket kan ske mindre än en gång i veckan, men som handledare så berättar de och förklarar hela tiden för eleven.

$\mathrm{Nja}$, ja det är klart vi pratar ju och förklarar ibland mitt i saker. Och när de frågar. Ibland frågar de ju medan vi är ute varför vi gör så och då 
förklarar man ju det. Men det är när vi sitter ner som vi kan prata. (Vivianne)

Medan handledning "på tu man hand" är synlig för alla handledare är ibland handledning "i farten" osynlig. Det är något som alla handledare pratar om att de gör men inte alla säger själva att det är handledning som de bedriver. Karin får upp ögonen för något hon inte såg innan när jag ber henne förklara vad hon kallar de samtal hon för med eleven under dagen.

Jag: När ni pratar under dagen om vad ni gör, vad är det då?

Då förklarar jag saker. Menar du att det också är handledning? Så har jag nog inte tänkt på det men om du säger så. (Karin)

Eftersom alla informanter beskriver att de gör mer än vad de ibland uppmärksammar själva kommer nästa tema bli en mer detaljerad beskrivning av alla de aktiviteter som de säger sig göra för att eleverna ska lära.

\section{Vad handledarna talar om att de gör för att stimulera elevernas lärande}

Hittills har jag beskrivit hur den handledning som handledarna beskriver vid intervjuerna organiseras och bedrivs. Handledningsmodellerna rymmer inte alla de lärtillfällen som handledarna erbjuder eleverna genom att de får delta i verksamheten. Här kommer uppmärksamheten att riktas mot alla de samlade aktiviteter som handledarna beskriver och som utgör den verksamhet och den handledning som eleverna möter. I detta tema blir den variation som handledarna talar om till subteman. Dessa subteman spänner mellan att handledarna beskriver hur de bjuder in eleven, visar/instruerar, ger utrymme, ger uppgifter, stöttar, förklarar och reflekterar tillsammans med eleven.

Det första subtemat blir när handledarna beskriver hur de bjuder in elever till deltagande i praktikgemenskapen genom att de tar emot eleverna på sin arbetsplats. Handledarna uttrycker att eleverna genom deltagande lär sig hur det kan gå till på en förskola. Här uttalar handledarna att det är viktigt för eleverna att få se många olika delar av förskolan och barnomsorgen och att verksamheten kan genomföras på olika sätt.

Det är inte bara att "göra förskoleverksamhet" som handledarna uttrycker att eleverna kan lära genom att vara med. Eleverna kan även lära sig att reflektera genom att vara med dem när de reflekterar menar en del handledare. Detta deltagande i olika aktiviteter uttrycks också som en början till att prova på och göra olika aktiviteter själv. Ingrid vill till exempel 
att hennes elever ska vara med på planeringsmöten för att de ska veta vad som ingår i jobbet.

Dels för att de ska veta hur det går till, för att veta vad som ingår i jobbet. Sätta sig in i rollen som personal. Det gäller att slussa in dem. Ofta sitter de med som betraktare, för att se hur det går till, de är inte så delaktiga i början så. (Ingrid)

Här beskriver Ingrid hur ett passivt deltagande ligger till grund för att senare delta aktivt. Att låta eleverna delta innehåller ofta en önskan från handledarna om att eleverna ska få möjlighet att se en mångfacetterad verksamhet. Anna ser en konsekvens för gymnasieelevernas lärande av hennes förskolas barncentrerade arbetssätt där barnen får vara med och bestämma mycket.

Ibland kan det ju vara så att barnen är inne i något så att de önskar samma saker så att då kan det ju bli lite tjatigt. (Anna)

Genom att delta i verksamheten kan eleverna enligt handledarna få vara med om exempelvis konflikter bland barnen. Om eleverna då känner att de vill och kan är det enligt handledarna bra om de försöker gripa in. Genom att vara med på detta sätt kan eleverna så småningom ta sig an uppgifter på egen hand. Genom att eleverna är accepterade deltagare som är integrerade i verksamheten och att de ser att deras deltagande spelar roll för verksamheten kan de också se sig själva som en del av praktikgemenskapen (Lave \& Wenger, 1991)

Paradoxen blir när handledarna säger att eleverna inte får vara med på alla förekommande uppgifter i förskolan. De aktiviteter som eleven kanske inte får vara med på kan vara specialpedagogisk handledning för personalen, personalmöten, utvecklingssamtal och planeringsmöten. Patricia förklarar hur hon tänker kring att låta elever vara med på planeringsmöten.

Nej, ja, för att när den här eleven kom, campuseleverna får mer än en som är från gymnasiet som går första året, eller andra till och med. Sen de får vara med på våra reflektioner och våra planeringar. Men de som går kommer från 9:an får inte vara med. Sen väljer man vissa saker där de kan vara med. (Patricia)

I sin position som handledare ställer Patricia elever utanför vissa arbetsuppgifter med hänvisning till vad hon menar att eleven är på arbetsplatsen för att lära, vad sekretesslagen säger och elevens individuella utvecklingsnivå.

Nästa subtema blir när handledarna talar om att de visar eller instruerar eleverna. Medan handledarna under det förra subtemat menade att 
deltagande i aktiviteterna ledde till yrkeskunnande finns det handledare som uttrycker att de behöver visa eleven vad som ska göras och hur. När handledarna pratar om att de "visar" eleverna något betyder "visa" två olika saker. Dels visa konkret hur jobbet kan gå till som till exempel Jenny och Susanne uttrycker det:

Titta på mig, så här gör jag! Och då försöker jag vara lite extra tydlig, nästan dramatisera lite, titta hur så ska vi se hur det går. (Jenny)

... så kan jag ta ner ett puzzel eller spel och så sätter jag mig och sen direkt så är det två, tre barn där som vill vara med. Då kan jag säga det att så här kan man göra. Allt behöver inte vara planerat eller man behöver inte fråga om någon vill spela spel med en. Tar man fram så kommer alltid några barn till en. (Susanne)

Det andra sättet som handledarna visar på är att de försöker uppmärksamma eleverna på situationer som de tror kan vara bra för dem att lära från.

Sen brukar jag visa dem situationer. Jag kan se saker som händer och viskande förklara för eleven, eller visa med fingrarna att, titta nu där! Då vill jag att de ska se, uppleva, hur barn kan vara, lära. När de förklarar för varandra eller bara leker väldigt bra. (Karin)

De handlingar som hittills har beskrivits av handledarna exemplifierar handledning "i farten" som beskrevs i resultatkapitlet Hur handledning går till under avsnittet Handledning i farten. En annan variant av att tala om att eleverna lär genom att utföra uppgifter är när handledarna talar om att de ger utrymme/backar för att eleverna ska kunna utföra arbetsuppgifter. Ett sätt som handledarna pratar om detta är att de säger att de medvetet låter bli att gå in i en situation för att ge utrymme åt eleven att agera. Berit och Karin talar om att hur de genomför aktiva handlingar för att eleven ska lära men även förhåller sig passiva för att stötta eleven i lärprocessen.

... man måste se till att de får göra sina grejer. Att man backar lite själv, att de får ta lite, vad som är viktigt. Att de får. /.../ Istället för att - nej, han eller hon fixar nog det där. Man behöver inte vara överallt. Tänka på hur man gör. (Berit)

Jag brukar försätta dem i situationer så att de ska får vara med om något och kunna ta ansvar. Jag kan backa för att de ska får svara på barnens frågor, ibland skickar jag fram dem om de är för blyga för att ta föräldrakontakt. (Karin)

När handledarna på detta sätt beskriver att de inte agerar för att lämna utrymme beskriver de hur de observerar och finns med i bakgrunden. 
Att ge uppgifter till elever är ett sätt som handledarna uttrycker att de ser till att eleverna kan delta aktivt. Att bara vara med på arbetsplatsen och se verksamheten räcker inte för att lära yrket menar vissa handledare. De uttrycker det som att eleverna är på arbetsplatsen för att lära, inte bara vara, och då behöver eleverna delta aktivt. För att ge eleverna möjlighet aktivt deltagande får de små uppgifter att genomföra.

Jag menar att de ska lära här, inte bara vara. Man lär genom att vara men det behövs nog mer än att bara vara. (Karin)

Efter ungefär en vecka tillsammans med handledaren i barngruppen är det dags för eleverna att prova på att göra aktiviteter med barnen. Eftersom eleven då har varit med barngruppen under en period vet eleven, enlig handledaren, vad den kan förvänta sig att barnen tycker om, klarar av och vilka förväntningar som kan ställas på dem. Genom att eleven har deltagit i verksamheten under en vecka har eleverna förmåga att utföra vissa arbetsuppgifter. Många handledare uttrycker att de ger eleverna små uppgifter under dagen för att de ska komma in i arbetet och lära sig se vad som behöver göras. Dessa små uppgifter kan till exempel vara att eleverna får ansvar för några barn vid en promenad. Det är enligt handledarna viktigt att eleverna får prova på och helst göra samma moment flera gånger för att lära.

Sen tycker jag att det är viktigt att de får prova, även om det står i materialet att du ska bara prova en sak så tycker jag att det är viktigt att de får prova fler gånger för att de ska stärka sin självbild också. Att de får prova, hur kändes det första gången, hur kändes det andra gången? Så tycker jag att det är viktigt. (Patricia)

Eleven var helt matt och slut efter att ha målat med tre stycken tvååringar, det tog 10 minuter men han blev svettig sa han. Efteråt sa han att han lärt jättemycket om hur olika barn är (Susanne)

... vill de prova så låter man henne göra det och ger det en chans. (Gunnel)

... men ändå låta dem försöka, de kanske inte vill ha hela aktiviteter. De kan inleda eller avsluta eller ha en del i det och utmana dem till att prova det. (David)

Ett sätt att lära är genom att göra fel säger flera handledare. Att göra fel kan handla om att den planerade aktiviteten inte blev som eleven hade tänkt sig och att barnen inte reagerade som de hade förväntat sig. Handledarna uttalar här att det är en värdefull upptäckt och ett bra lärtillfälle för eleverna. Att det inte blev som de hade tänkt betyder inte att det blev fel menar handledarna, det finns mer än ett sätt att göra det på. 
Detta tolkas här som att göra fel öppnar upp för reflektion kring vad som hände, varför det blev så och hur det går att göra annorlunda. För att stärka eleverna vill handledarna gärna att de ska prova igen efter att de har tänkt över planeringen och försökt hitta alternativa sätt att göra aktiviteten på eller bara att prova på att genomföra samma planering med andra barn för att se hur det går.

\begin{abstract}
Ibland när de har gjort uppgifter, planerat en lek och genomfört den och sen kan komma och säga att det blev inte alls som jag hade tänkt och så är de, en del är ledsna för att det blev fel och då får man förklara att det blir inte alltid som man har tänkt fast det innebär inte att det blev fel. (Susanne)
\end{abstract}

Det kanske har hänt också att vi har pratat om att det har varit något speciellt som man ville förklara att vi har gjort om en aktivitet. Gjort den en gång till, vad hade hänt om du hade gjort så här i stället eller om du hade tagit fram materialet innan? (Ingrid)

Man sågar ju dom inte för att de kanske provar en sak som inte vart jättebra att de känner att de går stärkta ur det där. Att de inte känner att usch det där blev tokigt, vi är ju aldrig fullfjädrade vi heller. Vi bollar saker med varandra varje dag fast vi har jobbat så länge. Att de kan känna att allt är föränderligt. (Ulla)

Genom deltagande i verksamheten kan eleverna enligt Ulla få vara med om hur de förhandlar om hur verksamheten ska utformas genom detta "bollande" (Wenger, 1998).

Att stötta eleverna är en uppgift som många handledare uttrycker ingår i rollen som handledare. Denna stöttning kan gå till på många olika sätt. Det som här identifieras som stöttning är där handledarna gör något för att stimulera elevens lärande.

Dessa handlingar som handledarna talar om kan vara att handledarna försöker vara positiva och inspirera eleverna genom att till exempel säga att "Det här ska väl bli kul?". De kan ge eleverna tips om vad de kan göra med barnen och konkret hjälpa eleverna vid planering av aktiviteter. Handledarna är även måna om att eleverna ska slutföra de uppgifter som de har med från skolan och pushar gärna eleverna till att jobba med dem. Stötta kan även innebära att handledarna ger eleverna positiv feedback på uppgifter som eleverna har gjort. Positiv uppmuntran på detta sätt framhåller flera handledare som ett bra sätt för att eleverna ska lära sig yrket. De berömmer eleverna och försöker påpeka de bra saker som eleverna gör.

För att komma in i jobbet kan handledarna gå vägen via barngruppen och låta dem medverka $\mathrm{i}$ att slussa in eleverna. De kan till exempel be 
barnen fråga eleven om hon eller han kan spela ett spel med dem eller om eleven kan hjälpa barnet med kläderna.

Ett annat exempel på stöttning kan vara när en handledare beskriver hur hon kallar till sig eleven för att hälsa på en förälder och därmed underlättar för eleven att göra något som annars kan upplevas som svårt att komma till skott med.

\begin{abstract}
Hjälpa dem i (rätt) riktning. Har de inte det (någon idé) så får man tycker jag bolla fram lite, det här och det här, vad som känns, vad de tycker. /... / Det är inte så lätt men jag kan ha ett förslag och sen så gör de det. Sen att de försöker göra de till sitt eget, att de tar min idé men gör det till deras egen. Det kan fungera. Sen kan jag ha haft en egen vision om det och så kommer det någonting annat men det är (skratt). (Fia)
\end{abstract}

Enligt vissa handledare räcker det inte med att visa hur man kan göra något för att eleverna ska lära hur yrket ska gå till utan att de behöver komplettera med att de förklarar. Till att förklara räknas när handledarna till exempel talar om att deras handlingar behöver sättas in i ett sammanhang. Det kan handla om att handledarna förklarar varför de väljer ett utflyktsmål och vilka tankar som ligger bakom. Det är deltagandet i aktiviteten tillsammans med denna förklaring som leder till att eleverna lär sig (Wenger, 1998). Handledarna kan behöva förklara det som inte är synligt vid till exempel en konflikt mellan två barn. Hit räknas även när handledarna pratar om att de berättar något för eleverna. Språket som bärare av praktikgemenskapens samlade kunskaper blir här tydlig (Wenger, 1998). Det finns de handledare som uttrycker att de förklarar mer när de har elever som inte fungerar så bra på förskolan. Att på detta sätt förklara sig för eleven är vad som gör att det blir något "extra" att vara handledare. Att vara handledare innebär inte så många extra arbetsuppgifter förutom att sätta in eleven i verksamheten och det görs till stor del genom att förklara.

Vivianne och Ulla berättar och visar för att förklara för eleven och att den ska lära hur de tänker kring att arbetet på förskolan bör går till.

Jag gör samma saker [när jag har elev] för det är ju det som behöver göras. /... / Men jag kanske gör det på ett litet annat sätt. En vanlig dag så förklarar jag ju inte vad jag gör men det gör jag när jag har elev.

Jag berättar allt, hur vi tänker kring det vi gör. / . . / Ja men jag berättar och visar. Hur planeringen ser ut och varför vi gör som vi gör (Vivianne)

Och sen kanske det är något speciellt som vi jobbar med under den tiden som de är här och då måste vi berätta det. / ... / Den [läroplanen]kommer väl oftast när man sitter och planerar. 
Ja man måste ju prata med dem, berätta hur dagen är upplagd. Det försöker man göra första dagen, hållpunkter under dagen, sen beror det på vad det är för kurs som de läser, vad de har för intresse. (Ulla)

Att reflektera tillhör yrket menar flera av handledarna. Detta är något som de ska göra varje dag och handledarna uttrycker att det är viktigt att eleverna får chans att reflektera kring händelser och genomförda aktiviteter för att lära yrket.

Handledarna pratar om reflektion på lite olika sätt. Reflektera betyder för handledarna att de tänker efter kring vad som har hänt eller hur någonting fungerar, ofta med syfte att utveckla verksamheten. Reflektionen kan vara en enskild handling som sker efter en aktivitet eller i arbetslaget då de tillsammans diskuterar hur verksamheten som helhet eller enskilda aktiviteter fungerar. Reflektionen tillsammans med eleverna beskriver handledarna sker verbalt men också att de uppmuntrar eleverna att föra dagbok och skriva ner vad som har hänt och vad de har sett för att själva reflektera kring. De dagboksanteckningar som en del elever har till uppgift att föra under praktiken menar ingen av handledarna att de har som uppgift att följa upp.

Elevens beteende gentemot barn och vuxna kan få handledare att reflektera över vad det får för konsekvenser och sedan ta upp det med eleven. För att stimulera eleverna att reflektera säger handledarna att de uppmanar eleverna att ställa frågor. Reflektionen menar någon kommer efter att eleven har genomfört en uppgift, exempelvis lett en aktivitet, som skolan har skickat med eleven att göra under APL. Att lära sig reflektera är något som eleverna borde ha med sig från skolan uttrycker några handledare. Här menar vissa att eleverna lär sig genom att delta vid personalens reflektioner medan andra menar att det krävs att eleven aktivt tränar sig i att reflektera.

Ett exempel på hur handledare kan arbeta med att öva eleverna i att reflektera är när Hanna säger att:

\begin{abstract}
Ja, att få prova på olika aktiviteter och att vi pratar om det hur det känns och viktigt just reflektioner, att de får reflektera över det. / ... / varför gjorde vi så här den här veckan till exempel. Eller, tänk vad det här barnet, vad den lyftes i den här aktiviteten. Att man får syn på saker att man får liksom en insikt vad är det egentligen som vi ska jobba med på förskolan. (Hanna)
\end{abstract}

Ett problem som framkommer är att handledarna anser att tiden inte räcker till för att gemensamt reflektera över vad som har hänt. Den reflektion som handledarna beskriver sker "i farten" räcker inte riktigt till eller är inte synlig för handledarna. Det är den stunden "på tu man hand" som handledarna anser krävs för att få till denna reflektion. 
Mitt resultat visar här att handledarna bjuder in eleverna att delta i verksamheten, de visar dem hur arbetet går till, vill att de ska göra och prova på för att lära och är själva ofta beredda att lämna plats för eleverna att prova på. När eleverna utför arbetet är handledarna där och stöttar och förklarar för dem. Några handledare talar också om att eleverna behöver reflektera för att internalisera den kunskap som de får genom deltagande och genom att utföra arbetet. Som en viktig grund för att lära ligger att eleven först känner sig trygga med handledaren och på arbetsplatsen. Beroende på vad handledaren låter eleven vara med på ger handledaren eleven möjlighet att lära olika saker. För att få tillgång till en bred repertoar (Wenger, 1998) av yrkeskunnande låter många handledare elever vara med om många olika arbetsuppgifter.

\section{Sammanfattning av resultaten}

När handledarna beskriver varför de har valt att fungera som handledare handlar deras berättelser ofta om att det är roligt och givande att vara handledare. Det är roligt att möta nya människor och det är utvecklande både för handledarna personligt och för arbetsplatsen. Mötet med eleven gör att handledaren behöver reflektera kring yrket. Att vara handledare betyder också att handledarna får möjlighet att vara med och påverka nykomlingars väg in i yrket. En del uppger att de vill att så många elever som möjligt ska välja att stanna kvar inom yrket medan andra uppger att de tänker mer restriktivt kring vilka de rekommenderar att fortsätta i yrket.

Då handledarna pratar om vad de anser att eleverna lär under APL gör det detta på två olika nivåer. Dels pratar de om vad de vill att eleverna ska lära sig och dels pratar de om vad de anser att eleverna lär. Det framkommer att handledarna vill att eleverna ska lära sig både generella arbetslivskunskaper som till exempel att komma i tid och yrkesspecifika kunskaper som bemötande, teoritillämpning och att reflektera för att utvecklas i yrket. Handledarna pratar om att eleverna lär sig både att bemöta barn och vuxna samt att tillämpa olika teorier under APL, medan de inte pratar om att eleverna lär sig att reflektera under APL.

När handledarna beskriver vad de gör som handledare är en viktig uppgift för dem att se till att eleverna trivs på arbetsplatsen och med yrket. De vill att eleverna ska ha roligt och uppleva perioden som stimulerande. Här talar en del handledare om elever som om det var barn som skulle skolas in i förskoleverksamheten. När de beskriver den handledning som de bedriver så berättar de om handledning som genomförs på två olika sätt. Alla beskriver hur de sitter ner "på tu man hand" med eleverna under cirka en timme vid ett till tre tillfällen under en APL-period. Många handledare beskriver också hur de visar eleverna hur någon kan göras, de backar för att ge eleverna utrymme att prova på olika arbetsuppgifter, 
de ger eleverna små uppgifter och de stöttar och förklarar för eleverna. Detta sätt att agera beskriver inte alla handledare som handledning. Handledning är när de sitter ner tillsammans med eleven och det andra är något de gör i alla fal när de har elev med i förskoleverksamheten. Det sistnämnde benämns här som handledning "i farten" och är många gånger osynligt för handledarna. 


\section{Diskussion}

I det här avslutande kapitlet kommer studiens resultat att diskuteras i förhållande till de perspektiv och det teoretiska ramverk som har presenterats. Syftet med studien har varit att studera handledning och den yrkesutbildning som handledarna på förskola möjliggör genom att ta emot elever från Barn- och fritidsprogrammet (BF) på sin arbetsplats. Mer precist handlar studien om att studera och förstå handledning och yrkeslärande på förskola ur handledarnas perspektiv och de motiv som ligger bakom handledarnas engagemang, vilka kunskaper och förmågor som eleverna bör lära och lär under denna period samt vad handledarna gör för att eleverna ska komma in i praktikgemenskapen.

I den första delen diskuteras förskolan som praktikgemenskap och hur man med hjälp av situerat lärande kan se på handledare i praktikgemenskapen förskolan. Efter det diskuteras hur handledning organiseras och går till samt olika sätt att se på handledarskapet och vilken roll APL har i yrkeslärande. Diskussionen avslutas med implikationer för gymnasieutbildning och förskolan samt förslag på fortsatt forskning.

\section{Förskolan som praktikgemenskap}

Utifrån det teoretiska ramverket kring situerat lärande kan förskolan ses som en praktikgemenskap. Praktikgemenskaper består enligt Wenger (1998) av människor som ömsesidigt engagerar sig i ett gemensamt uppdrag. Praktikgemenskapen kan här ses både som det kollektiv som alla förskolor tillsammans utgör och den enskilda förskolan. Förskolan som helhet är till för att uppfylla ett politiskt mål om att förse föräldrar och barn med en trygg och utvecklande miljö medan föräldrarna arbetar och ge alla barn en god start i livet. Det gemensamma officiella syftet med personalens engagemang inom förskolan som helhet är alltså att skapa en god pedagogisk miljö för barnen och på så sätt uppfylla läroplanen för förskolan (Skolverket, 1998/2010). Förskolan, både som helhet och varje enskild förskola, innehåller på så sätt alla de delar som Wenger (1998) beskriver att en praktikgemenskap har. Genom att förhandla om hur verksamheten ska bedrivas skapar personalen som kollektiv ett gemensamt språk och en uppsättning tankar och handlingsmönster för att utföra arbetet vilket blir den gemensamma repertoaren (Wenger, 1998).

Den enskilda förskolan är en del i denna helhet och personalen delar officiellt målet med kollektivet, men varje enskild deltagare i förskolans praktikgemenskap bidrar med sina egna personliga mål till kollektivet (Wenger, 1998). Personalens enskilda mål kan både samstämma med 
och motverka kollektivets uttalade målsättning. På den enskilda förskoleavdelningen ger deltagarnas personliga mål ett avtryck och verksamhetens utformning och mål kan därför komma att variera mellan olika förskolor. Med stort utrymme för personalen att utforma verksamheten blir det arbetssätt som personalen på den enskilda avdelningen utarbetar också den utbildningsmiljö som eleven möter. Beroende på vad personalen vill och kan erbjuda för verksamhet kommer det att påverka elevens möjligheter till vidare deltagande i praktikgemenskapen.

\section{Gymnasieutbildning på förskola}

Gymnasial yrkesutbildning kan sägas stå mellan två kulturer, både skolkulturen och arbetsplatsens kultur kommer att påverka utbildningen och eleven (Berner, 2010). När gymnasieeleverna är på förskolan under den arbetsplatsförlagda delen av utbildningen har gymnasieutbildningen bytt sammanhang från den vanliga skolmiljön till arbetsplatsen. Gymnasieskolan har därmed flyttat in i förskolan och lärandet blir situerat där. Medan förskolan som praktikgemenskap och Barn- och fritidsprogrammet står nära varandra på så sätt att de delar ett gemensamt undervisningsspråk och -kultur är de vanligen åtskilda under stora delar av elevernas utbildning. Så som tidigare beskrivits är det extra svårt för Barn- och fritidseleverna att i skolmiljö komma åt en adekvat lärmiljö vilket gör praktikplatsen förskolan och verksamheten där extra viktig. Med Gy11 skrivs den arbetsplatsförlagda tiden fram som än mer viktig (SFS 2010:2039) och med den även handledaren. Nu finns det också ett ökat politiska intresse för lärlingsutbildningar där eleven kommer att spendera mer tid på arbetsplatsen (SOU 2011:72). Det blir då än viktigare att beakta de konsekvenser detta får för alla inblandade.

Oavsett lärmiljö är det läroplanen för gymnasieskolan som gäller för eleverna och det är gymnasieskolan som har ansvar för att läroplanen följs även under APL. Det framkommer i studien att handledarna inte organiserade någon speciell verksamhet för att eleverna skulle kunna genomföra eller uppnå de kursmål som de hade med sig från gymnasieskolan under APL, det var under det dagliga arbetet som målen skulle uppnås. Mot bakgrund av resultaten kan det diskuteras vilken läroplan som handledarna har i åtanke när de möter eleverna från Barnoch fritidsprogrammet. Handledarna i studien talar om eleverna i ordalag som för tankarna till hur de talar om barn som ska skolas in i förskoleverksamheten. Det som i studien identifieras som "grundläggande faktorer för lärande" kan kopplas till det språk som används om barn som ska vänjas vid förskolan. När handledarna talar om att praktikperioden ska vara "jagstärkande" och att det är viktigt att eleverna upplever att det tiden på förskolan är "rolig" kan det tolkas som att handledarna väljer att skola in eleverna på förskolan i stället för att ge dem en utbildning till 
barnskötare. Det kan diskuteras om detta leder till ett konserverande av etablerade arbetssätt(Ellström, 2004; Fuller \& Unwin, 2004).

\section{Lärande genom legitimt perifert deltagande}

När man väljer att se på förskolan som en praktikgemenskap och det yrkesutbildning som pågår där som lärande genom perifert deltagande följer att förhandlingar om vad praktikgemenskapen går ut på blir något centralt. I denna process har handledaren en central roll som den person som har möjlighet att släppa in eleverna i praktikgemenskapen. Studien visar att handledarna genom att erbjuda eleverna att delta i verksamheten släpper i dem och ger dem möjlighet att lära genom deltagande. Lärandet kommer dock att påverkas av hur verksamheten ser ut på den aktuella förskolan.

Ansvaret för ett aktivt deltagande från elevernas sida kan inte läggas på handledaren enbart. Yrkesläraren och gymnasieskolan är ansvariga för utbildningens kvalité och har som ansvar att se till att alla elever kan tillgodogöra sig utbildningen. Eleverna behöver dock hjälp även från handledarna med att förstå hur yrkeslärande kan gå till. De som inte har förmåga att agera aktivt riskerar att stanna kvar i en perifer position då de kan uppfattas som inaktiva eller ovilliga att utföra arbetsuppgifter. Elever som exempelvis inte vill ta rast tillsammans med handledare och övrig personal eller inte anser sig behöva handledning kommer därmed att missa tillfällen till yrkeslärande genom att höra hur personalen talar om yrket (Lave \& Wenger, 1991).

En annan del av praktikgemenskapen är styrdokumentet Läroplanen för förskolan (Skolverket, 1998/2010) som kan ses som en artefakt. Eftersom den är skriven på ett sådant sätt att det är upp till varje arbetslag att fritt utforma verksamheten som de anser bäst gynnar den aktuella barngruppen utifrån de lokala förhållandena. På detta sätt är verksamheten under ständig omförhandling beroende på barnens behov men även på personalens kompetens, ambitioner och erfarenheter. Eftersom förskolepersonalens arbetsuppgifter är så vagt formulerade som beskrivits är det upp till arbetsgruppen att tillsammans definiera med vad och hur de ska arbeta. Detta gör att graden av förhandling om hur uppdraget ska utföras är hög och handlingsfriheten är stor. Genom att arbetslaget tillsammans planerar och utvärderar verksamheten förhandlar personalen om meningen med det de gör. Vid dessa förhandlingar sker det som kan ses som ett kollektivt tänkande, erfarenheter och tankar utbyts i diskussion. De medlemmar som kan språket och är väl insatt i sammanhanget kommer att ha lättare att påverka hur uppdraget ska definieras och utföras. Genom att vara med och få lyssna på dessa medlemmar och se hur denna förhandling går till kan eleverna lära detta på förskolan. Om eleverna sedan dessutom får ställa frågor och de erfarna 
lyssnar på eleverna kan de även utveckla förmåga att uttrycka sig i denna förhandling. Handledaren kan därmed underlätta elevens deltagande mot att bli en fullvärdig medlem i praktikgemenskapen. Men om eleven inte ens blir insläppta på dessa möten kommer de missa en del av kärnan i praktikgemenskapen (Wenger, 1998).

\section{Identitetsskapande}

Vid yrkesutbildning på arbetsplatsen finns en spänning mellan att utveckla en egen identitet och att bli lika de som finns i ens närhet (Sundli \& Söndenå, 2007). Om handledarna strävar efter att eleverna ska bli så lika dem själva som möjligt kommer det att leda till en homogen praktikgemenskap där personalen tänker och handlar inom snäva ramar. Hur uppdraget utförs kommer då se väldigt lika ut mellan olika avdelningar och förskolor. Det framkommer i studien att ta hand om gymnasieeleverna är ett gemensamt åtagande för all personal på avdelningen. Detta motiveras med att eleverna då får chans att se flera olika sätt att utför verksamhet på och flera olika personer att fråga och samtala med. En aspekt av identitetsutveckling bland medlemmarna i praktikgemenskapen är att förskolan är en genuspräglad arena med kvinnlig dominans. Historiskt har formandet av identitet varit central i utbildningen till förskollärare och förskolan som praktikgemenskapen är en feminin arena som består och görs av kvinnor. Detta kommer att prägla verksamheten och de identiteter som skapas genom deltagande (Tallberg Broman, 1991; SalminenKarlssson, 2005). Detta kan problematiseras i förhållande till handledaren och handledarens roll. Då genus är ett centralt begrepp i förskolans styrdokument (Skolverket, 1998/2010) blir det även viktig hur personalen agerar gentemot varandra på arbetsplatsen. Den goda samstämmighet och det som Tallberg Broman (1991) benämnet "inomgruppskultur" som råder i förskollärarkåren kan riskera att utestänga många från praktikgemenskapen. De elever som inte lyckas framstå som tillräckligt engagerade kommer att ha svårt att få tillgång till lärande miljöer. Eftersom den svenska arbetsmarknaden till stor del är könssegregerad (SCB, 2012) är det viktigt att varje handledare får kunskap om hur både tjejer och killar kan ges lika möjligheter att delta i arbetet på förskolan.

\section{Hur handledning för yrkesutbildning organiseras och går till}

Handledning står i den här studien för det som Caplan (1970) definierade som "supervision". Detta eftersom det handlar om handledning i en hierarkisk situation i likhet med Wengers (1998) teori som bygger på att "oldtimers" är de som introducerar nykomlingar i praktikgemenskapen. Den handledning som informanterna i studien beskriver liknar både det 
som Handal och Lauvås (2001) beskriver som lärlingsmodellen och det som benämns handling och reflektionsmodellen. Den handledning för yrkeslärande som har identifierats i den här studien är i de flesta fall en kombination av båda modellerna. Min studie visar att handledarna bedriver handledning på två olika sätt vilka här benämns "på tu man hand" och "i farten".

\section{Organiserad handledning}

När handledarna på direkt fråga berättar vad de gör som handledare är det ofta det som här benämns handledning "på tu man hand" de talar om. Detta är det organiserade och uttalade sättet att bedriva handledning och något alla medvetet gör och har tankar kring. Denna handledning beskriver handledarna sker bakom stängd dörr och i fred från barngruppen. Vid dessa tillfällen finns det enligt handledarna tid och möjlighet för dem att lyfta frågor som har uppkommit under arbetet i barngrupp. Det finns även tid att fundera kring lösningar, att relatera till teorier och att fundera över alternativa lösningar på situationer. De frågor som inte kan diskuteras med barn och föräldrar närvarande kan här lyftas och förklaras. Analysen visar att de handledare som arbetar enligt handling och reflektionsmodellen och som är bra medreflekterande som har förmåga att lyfta enskilda situationer till generella exempel kan ge eleverna stora möjligheter att utveckla sitt eget yrkeskunnande genom reflektion. I denna modell kan nykomlingens egna styrkor och personlighet få komma fram och utvecklas (Lauvås \& Handal, 2001).

Vid handledningssamtal där både handledaren och nykomlingen får plats finns även utrymme för handledaren att lära av elevens frågor, erfarenheter och tankar. Men, den handledaren som enbart handleder "på tu man hand" för att "det är så man gör" men utan att reflektera kring yrkesspecifika frågor kan lämna eleven med få goda exempel och förklaringar på hur arbetet kan utföras. Därigenom kan både elev och handledare komma att missa möjligheten till förhandling, lärande och utveckling. En annan konsekvens blir att handledning "på tu man hand" skiljs från den egentliga verksamheten och därigenom blir mer lik skolförlagd utbildning. Yrket blir något som görs "där borta" och en av fördelarna med APL som situerat lärande går förlorade. En följd av detta kan bli att den i skolan konstruerade uppdelningen mellan teori och praktik består och framstå som en reell skillnad (Tanggaard, 2007). När ett av problemen som framhålls vid skolförlagt lärande förstärks på detta sätt på arbetsplatsen kan det begränsa elevernas möjlighet att komma in i praktikgemenskapen och lära yrket (Fuller \& Unwin, 2004).

Vidare berättar handledarna att de under denna handledning bland annat ställer frågor för att uppmärksamma eleverna på olika situationer som har uppstått. Bland andra Sundli och Sönderås (2007) forskning visar 
att denna form av handledningssamtal är svåra att bedriva. Korta frågor dominerar och handledarna tar mer tid i samtalet än eleven och den traditionella relationen mellan lärare och elev kvarstår. Att dessutom anta att det som sker i dessa samtal alltid är av reflekterande art tror jag är en för långtgående slutsats att dra. Handledning för reflektion är svårt (Sundli \& Sönderås, 2007; Handal \& Lauvås, 2001).

\section{Oorganiserad handledning}

Oorganiserad handledning får här stå för att den inte är planerad och schemalagd. Studiens resultat visar att mycket av den handledning som handledarna beskriver sker medan det vanliga arbetet pågår, något som här benämns som handledning "i farten". Tydligt i studien är att denna form av handledning inte allid uttryckligen definieras som handledning av handledarna medan det är på detta sätt som Lave och Wenger (1991) beskriver att situerat lärande går till; eleven får vara med i det vardagliga arbetet, se hur det går till och allt eftersom får eleven mer och mer ansvar för att sedan kunna utföra allt fler och mer komplicerade arbetsuppgifter. Vid handledning "i farten" blir yrkeslärandet situerat. Med en handledare vid sin sida kan eleven prova på, be om hjälp samt få feedback i situationen och en förklaring till hur uppgiften kan utföras.

Om handledning för yrkeslärande reduceras till att bara ske "i farten" och längre tid för reflektion och frågor uteblir kan följden bli att eleven går från den arbetsplatsförlagda delen av utbildningen med att uppfatta händelser utifrån sin begränsade erfarenhet och kunskap. Det kan bli upp till nykomlingen själv att skaffa sig förståelse för vad som hände och varför. Eleven missar en del av den förhandling som det innebär att motivera och förklara varför något utförs som det gör (Wenger, 1998). Om handledaren på detta sätt begränsar elevens deltagande kan det leda till att handledaren är ett hinder för elevens fortsatta utveckling (Fuller \& Unwin, 2004). Istället för deltagande mot fullvärdigt medlemskap i praktiken (Lave \& Wenger, 1991) kan eleven bli kvar ute i periferin med små möjligheter att avancera. Även handledaren missar här chanser till egen utveckling då elevens tankar kanske inte fångas upp.

Mina resultat visar alltså att handledarna ofta talar om handledning på ett sätt ("på tu man hand") men sedan även handleder "i farten". Om handledarna själva bara definierar det de gör "på tu man hand" som handledning kan det få konsekvenser för vad handledaren kommer att betona som viktigt för eleven. De ämnen eller situationer som handledaren finner centrala och av vikt eller som eleven frågar om vid handledningstillfället kommer att behandlas och diskuteras. Den förhandling som pågår vid möten, på studiedagar eller vid samtal för att lösa problem som uppstår i vardagen kan komma bort. Den form av reflektion som kommer att kunna förekomma är reflektion i efterhand. En annan 
konsekvens av att handledarna inte se det arbete som de utför som handledning kan bli att handledning " $i$ farten" inte prioriteras och ges tid till. Att genomföra rutinarbete och samtidigt tillåta eleven att pröva och ställa frågor tar mer tid än att göra det själv. Detta innebär att tid för handledning blir en central fråga även om handledningen görs "i farten"(Billett, 2003).

\section{Att sätta gränser för yrkeslärande}

Studiens resultat antyder även att det finns handledare som delar upp sysslor på arbetsplatsen som de låter respektive inte låter gymnasieeleverna delta i. Konsekvensen kan bli att eleven förblir en person som står och tittar på utan att ha möjlighet till ett aktivt deltagande. Att lita på att eleven kan och vill och att låta denne göra saker - och kanske göra på ett annat sätt än hur handledaren hade gjort - blir en avgörande faktor för elevens möjlighet att lära. Precis som eleven behöver engagera sig i uppgifter behöver handledaren ta ett steg tillbaka. Att reflektera över sina handlingar är ett sätt för eleven att utvecklas i yrket (Molander, 1996; Schön, 1983/1995). För att kunna reflektera behöver eleven få prova på att utföra arbetsuppgifter, och när handledarna beskriver att de backar och ger eleverna uppgifter skapar de därmed utrymme för eleverna som då får möjlighet att skaffa sig erfarenhet. Detta kan handledarna sedan ta vara på genom reflektion i handlingen eller vid ett senare tillfälle.

Eftersom yrket inom förskolan beskrivs som individuell och erfarenhetsutvecklat (Ekström, 2007) kan det ses som viktigt att varje individ får möjlighet att utveckla sina egna styrkor och sin egen yrkespraktik. Om handledaren har en snäv bild av hur en blivande kollega i praktikgemenskapen ska vara kan handledaren därigenom bli en begränsande faktor för lärandet. Handledaren sätter upp ramar för hur yrket ska utföras som egentligen inte finns där. Om handledning enbart bedrivs "i farten" kan exemplen på hur yrket kan utföras även här blir för få för att eleven ska kunna utveckla en egen repertoar (Wenger, 1998) av kunskap och lösningar för att utföra yrket. För att ha möjlighet att hitta sitt eget sätt kan tillfällen där alternativa lösningar och konsekvenser för arbetet på förskolan kan diskuteras komma att bli viktiga. Eftersom tiden på förskolan är relativ kort för gymnasieeleven finns inte alltid tiden till att vara med om allt. Den korta tiden på arbetsplatsen kan till viss del kompenseras med att handledaren generaliserar ur enskilda händelser.

\section{Finns det ett bästa sätt?}

Är ett av sätten att organisera handledning bättre än det andra? Eftersom sammanhanget här handlar om yrkeslärande kanske frågan i stället borde vara; Ger det ena eller andra sättet att handleda nykomlingen bättre och enklare tillgång till de yrkeskunskaper som finns i praktikgemenskapen? 
Det slutgiltiga svaret på frågan finns nog inte, då handledning sker på olika sätt för varje handledare, elev och dessutom beror på situationen. Resultaten i denna studie visar att de båda sätten ofta används bredvid varandra och även att de kompletterar varandra och tillsammans ger elever tillgång till det yrkeskunnande, det språk och den kultur som finns inom praktikgemenskapen förskolan.

Ett viktigt resultat av studien är att det är betydelsefullt att handledarna sätter ord på vad de gör och blir medvetna om sina handlingar och dess konsekvenser. Det kan också diskuteras om inte handledarna som i studien uppfattade att de saknade både tid och möjlighet att bedriva handledning "på tu man hand" skulle vara lite mer nöjda med sin insats om de förstod att de kompenserade för detta genom att lägga mycket tid och möda på handledning "i farten". De handledare som föredrog att handleda "i farten" men upplevde att de inte hade tid till det kanske skulle utföra uppdraget bättre om de inte gick ifrån verksamheten för att sitta ner utan aktivt bedrev handledning medan verksamheten pågick. Poängen är här att ta vara på och synliggöra den handledning som bedrivs istället för att ha dåligt samvete över sådant som det inte finns tid till. Det kan komma positiva effekter ur båda sätten att handleda och hur handledningen ska bedrivas är upp till handledarna att avgöra. För att ta vara på de positiva effekterna av båda sätten blir det alltså än en gång viktigt att synliggöra dessa effekter. Handledning skulle därmed bli en mer medveten handling och de positiva effekterna av de båda sätten att handleda som har identifierats i studien kan förstärka varandra. För förskolan som praktikgemenskap och utbildningsplats kan en kombination av de båda sätten dessutom vara det mest givande sättet att bedriva handledning. Barnens, och även ibland andra vuxnas närvaro, gör att allt inte går att prata om så länge och på det sätt som det behövs för att kunna lära ur många av situationerna som uppstår i vardagen.

\section{Handledaren}

Som det framgår av bakgrundsbeskrivningen behöver inte handledaren för gymnasieelever någon annan formell kompetens än att än att ha nödvändiga kunskaper och erfarenhet och anses lämplig (SFS 2010:2039). Förutsättningarna för Barn- och fritidsprogrammet skiljer sig från andra program då handledarna har pedagogisk utbildning och är vana att organisera för lärande (Skolverket, 1998/2010).

\section{En oldtimer som lär}

Handledarna som här ses som "old-timers" (Wenger, 1998) är en viktig länk för eleverna när de ska erövra det yrkeskunnande de behöver. De som avgör om nykomlingen, i det här fallet eleven, blir insläppt i 
praktikgemenskapen är främst handledarna. De har olika lång erfarenhet men de är alla "old-timers" i förhållande till gymnasieeleverna som är nykomlingar. Nykomlingen kanske kommer till praktikgemenskapen utan egentliga erfarenheter av förskolan men med andra kunskaper som förskolan kan dra nytta av (Unwin \& Fuller, 2004). En gymnasieutbildning är idag tre år och innehållet har förändrats mycket sedan många av handledarna gick sin utbildning. Eleverna kan på detta sätt bidra med kunskap som kan vara viktig för praktikgemenskapen. Många ungdomar är idag uppväxta i en annan kulturell mångfald än tidigare generationer vilket kan bidra till en annan kulturell kompetens än vad äldre handledare har. Om handledarna har förmåga att själva anta en lärande roll finns det möjligheter för dem att fånga upp idéer och tankar som eleverna har med sig in i praktikgemenskapen.

Ett av resultaten i studien som har berörts till viss del är att handledarna uppger att de själva utvecklas i mötet med eleverna som de handleder. Informanterna i studien beskriver hur elevernas frågor leder till att de behöver fundera över bland annat sitt agerande vilket leder till ett synliggörande för dem. Bland andra Huzzard (2004) kritiserar Lave och Wenger och skriver att de inte problematiserar maktstrukturer i situerat lärande. Hierarkier kan vara bra för lärande då det är tydlig vem som är erfaren och vem som lär, men lärande kan också uppstå när hierarkierna bryts (Huzzard, 2004). Om hierarkin mellan elev - handledare kan brytas och handledaren undrar vad eleven ser och vad som framstår som annorlunda på den aktuella arbetsplatsen jämfört med tidigare erfarenheter eller vilka frågor eleven har så kan kunskapsutbytet mellan elev och handledaren öka. Just detta kunskapsutbyte skulle kunna främja handledaren och arbetsplatsen om de såg eleven som bärare av kunskap från gymnasieskolan och mellan arbetsplatser. Den yrkeserfarenhet som nykomlingen saknar kan kompenseras med naiva frågor som öppnar upp för reflektion och förhandling. Informanterna i studien pratar om hur elevernas frågor gör att de behöver tänka efter kring varför de gör som de gör och därigenom blir de medvetna om förgivet taganden som de tidigare inte hade uppmärksammat. Reflektionen som kan uppstå i mötet med eleven kan på så sätt stärka handledaren i dennas yrkesroll.

Bara för att handledaren är definieras som en "old-timer" behöver inte innebära att den mest seniora medlemmen alltid är den som är bäst på att handleda. Den som nyligen har lärt yrket kan också vara den som har bra insikt i vad som var svårt och vad som är viktigt för att komma in i praktikgemenskapen. Olika personer kan bidra med olika sätt att se på verksamheten och olika lösningar på situationer. 


\section{Olika sätt att se på och göra handledning}

En viktig aspekt av uppdraget att vara handledare var för informanterna att de ansåg att eleverna behövde komma ut på arbetsplatsen för att se vad yrket innehöll och hur arbetet kunde gå till. Med sin position som erfarna ville de dela med sig av denna kunskap och insikt i yrket. De motiv handledarna har för att ta sig an uppdraget kan få konsekvenser för hur de sedan utför uppdraget. Om handledare, medvetet eller omedvetet, går in med syftet ge eleverna en inblick i arbetslivet eller om de gör det med utgångspunkt $\mathrm{i}$ att APL-perioden ska vara en del av en professionell yrkesutbildning får konsekvenser för hur de sedan kommer att genomföra uppdraget, vad de väljer att visa eleverna samt hur de bedömer dem. Om handledaren ser APL som ett sätt för eleven att få inblick i arbetslivet kan handledningen reduceras till något ytligt och generellt. Handledaren kan om så är fallet nöja sig med att visa upp förskolan som en arbetsplats som vilken som helst och nöja sig med att eleven kommer i tid och är en trevlig kollega. De djupare yrkeskunskaperna och praktikgemenskapens gemensamma repertoar av kunskap och traditioner kan komma i skymundan (Wenger, 1998). Om handledaren däremot ser tiden på arbetsplatsen som en del av en yrkesutbildning där eleven lär genom att få vara med i alla de delar som yrket innehåller och blir insläppt i de innersta rummen och därigenom får tillgång till praktikgemenskapens språk och kultur så har eleven stora möjligheter att lära mycket.

Trots att arbetet i förskolan ses som viktigt av alla handledare finns det i min studie de som uttrycker att de selekterar vilka elever de vill rekommendera att fortsätta inom förskolan. De definieras här som "grindvakter" som genom sin position som handledare kan välja att rekommendera de som de tycker passar in på förskolan och genom kontakter underlätta deras fortsatta bana i yrket och praktikgemenskapen. På detta sätt har de makt att selektera vilka elever de tycker hör hemma i praktikgemenskapen och vilka de vill hålla utanför. Handledarnas subjektiva bedömning av eleven kan medföra att vägen in i praktikgemenskapen underlättas med hjälp av handledarens rekommendationer eller försvåras i de fall handledaren inte tycker att eleven passar in. När praktikplatsen väljer att använda en del elever som vikarier framför andra får dessa arbetslivserfarenheter som ses som positivt på arbetsmarknaden. Handledaren har i dessa fall stort inflytande på elevernas möjligheter att komma in i praktikgemenskapen. Ur denna synvinkel blir handledarna en klar maktfaktor som kan komma ha stor påverkan på elevernas framtid (Huzzard, 2004). Även de handledare som här definieras som "inkastare" då de talar om att det tycker att de är viktigt att visa att förskolan är en arbetsplats som passar alla kommer att ha makt över elevens framtid i praktikgemenskapen. Den handledare som inte 
visar på komplexiteten i yrket och de krav som ställs kan invagga eleverna i en falsk trygghet om vilka krav som kommer att ställas i framtiden.

De beteenden som handledaren ser och identifierar som att eleven inte är så engagerad i yrket kan också vara tecken på till exempel osäkerhet från elevens sida. Om handledaren är snabb med att avfärda eleven som ointresserad och därför inte lägger någon större kraft på att slussa in den i praktikgemenskapen kommer eleven att få svårt att komma vidare. Den elev som däremot möter en arbetsplats och kollegium som uppfyller de expansiva kriterier som Fuller och Unwin (2004) definierar kommer att ha stora möjligheter att utvecklas i yrket.

Utifrån Lave och Wengers (1991) begrepp legitim perifer deltagare så visar studien att eleverna kan gå som legitima deltagare mellan olika verksamheter och på så sätt kan de fungera som länkar mellan olika förskolor, mellan förskolan och gymnasiet och vice versa. Genom APLsystemet har eleverna en legitim perifer plats på förskolorna och genom sin status som nykomlingar kan de utföra arbetsuppgifter på ett sätt som kanske skiljer sig från hur de i vanliga fall utförs på den aktuella arbetsplatsen. De kan också (ibland på handledarnas frågor) berätta hur de har gjort på tidigare arbetsplatser och vad de har lärt i skolan i ämnet. Elevernas deltagande påverkar på så sätt inte bara deras egen identitet utan även handledarens och verksamheten (Wenger, 1998). Handledaren får tillfälle att reflektera både över sitt eget agerande och över hur verksamheten är organiserad. Handledaren kan på detta sätt utvecklas och stärka sin identitet.

Studien visar på ett decentraliserat handledaruppdrag (Nielsen \& Kvale, 2000) då alla handledare betonade att de, tillsammans med arbetslaget, hjälptes åt med att ta hand om eleven. När ett helt arbetslag engagerar sig och tar ansvar för eleverna kan det leda till att eleverna får tillgång till många olika sätt att uppfatta yrket, får höra på många olika förklaringar och se olika lösningar på arbetsuppgifterna. Om det är så, och hela arbetslaget delar med sig av sina kunskaper och därmed också får tillgång till de fördelar som det visar sig kommer med handledaruppdraget kan det vara utvecklande för arbetslaget. När arbetslaget låter eleven vara med på exempelvis planeringsmöten, det som här definieras som förhandlingar om hur det gemensamma uppdraget i praktikgemenskapen ska utföras, och dessutom förklarar syftet och bakgrund till mötet och vad det förväntade resultatet är så synliggörs det som annars kan vara dolt och kanske bortglömt för flera inblandade. Det arbetslag som handleder elever kommer alltså att ha en mer aktiv och synlig förhandling om hur verksamheten på förskolan ska organiseras och bedrivas. I det fall där eleven blir en enskild angelägenhet för handledaren, som upplever att tid saknas för att bedriva handledning på ett bra sätt, kan handledaren komma att uppleva uppdraget som mer betungande än givande. På det 
sätt som handledning förekommer på förskolan finns ingen renodlad mästar-lärlingrelation mellan handledaren och eleven (Nielsen \& Kvale, 2000). Eleven och handledaren går visserligen bredvid varandra men det är eleven som ska upptäcka sitt eget bästa sätt att utför yrket på. Det finns heller inget "rätt sätt" att utföra yrket på, när man har med människor att göra är det förhållningssätt och strategier som bör utvecklas. Om det är så att det är eleven som ska hitta sitt sätt att utför arbetet på minskar risken för att lärandet blir av reproduktiv art.

\section{Vad eleverna lär och inte lär}

När handledarna i studien talar om vad de vill lära eleverna lyfter de fram områden som social kompetens, teoritillämpning och reflektion som viktiga områden. Det situerade lärandet poängteras implicit av handledarna och i interaktionen mellan eleven - barnen - föräldrar ser handledarna elevernas sociala kompetenser och hur de tillämpar olika teorier som är kopplade till yrket. När handledarna senare talar om vad de anser att eleverna lär finns det ett glapp när de inte talar om reflektion som något de uppfattar att eleverna lär sig. Detta glapp kan bero på flera saker. En anledning kan vara valet av metod och att intervjufrågorna i den här studien inte berörde ämnet nog mycket. En annan anledning kan vara att reflektion är något som ofta sker i tystnad (Schön, 1983/1995). Tiden på arbetsplatsen kan också vara relativt kort och det kan behöva finnas distans till handlingen innan det går att reflektera över den (Molander, 1996). Det egentliga svaret på frågan vad eleverna lär kan heller inga andra än eleverna själva svara på. Om det ska ske ett utvecklingsinriktat lärande under den arbetsplatsförlagda tiden är det viktigt att se till att handledarna ger eleverna möjlighet att utvecklas. När Sundli och Söndenå (2007) ser att handledning blir ett sätt att kontrollera elevernas reflektion och därmed begränsa elevernas handlingsutrymme tror jag att de är inne på ett viktigt spår. Att ge handledarna kunskaper att se sitt eget agerande och dess konsekvenser för eleverna och praktikgemenskapen borde skapa förutsättningar för ett utvecklingsinriktat lärande för alla. Eleven som nykomling och handledaren som "oldtimer" (Wenger, 1998) har mycket att lära av varandra.

För att ge eleverna möjlighet att lära så mycket som möjligt och för praktikgemenskapen ska utvecklas blir slutsatsen att handledarnas attityd till nykomlingar och hur handledaruppdraget genomförs blir centralt. När eleverna som en del av aktivt engagemang ställer frågor får handledarna möjlighet att utvecklas själva. Deras identiteter som en del av förskolan stärks när de behöver förklara och legitimera sitt och arbetsplatsens agerande. 


\section{Varför APL?}

Den av riksdagen bestämda gränsen på minst 15 veckors APL på yrkesprogram (SFS 2010:800) visar sig vid utvärderingar gärna också bli en övre gräns (Skolinspektionen, 2011). Om kunskap definieras som att det är något som alltid ska relateras till en speciell situation blir det arbetsplatsförlagda lärandet ett viktigt inslag på en yrkesutbildning. APLperioden blir då en viktig tid för att lära och utveckla de kunskaper som ska komma att användas i yrkets praktikgemenskap. Barnskötaryrket är ett praktiskt yrke som ska läras. Den öppna skrivningen av läroplanen för förskolan öppnar upp för att arbetet går att utföra på många olika sätt och gör att den repertoar (Wenger, 1998) av sätt som personalen utarbetar för att utföra yrket är stor och svår att greppa. Under utbildning är det viktigt att få se någon utföra arbetsuppgifterna, att vara med och lyssna på förhandlingar om meningen med uppdraget och själv få prova på att göra arbetsuppgifterna på plats. Att det krävs mognad och insikt bland de som ska visa eleverna vägen in i denna snåriga djungel av möjliga vägar är tydligt. Eleverna behöver få observera, prova på, hitta sitt eget sätt att utföra uppdraget på och förhandla om detta tillsammans med andra för att kunna utveckla de förmågor som yrket kräver.

En fråga man kan ställa sig är om det inte räcker med att ha duktiga yrkeslärare på gymnasieskolorna, spelar handledarna så stor roll? Tidigare forskning visar till exempel att lärarna på Barn- och fritidsprogrammet inte alltid är utbildade för de kurser de undervisar i (Lemar, 2001) och även att yrkeslärare som grupp ibland bara har några få år i yrket som de utbildar för (Fejes \& Köpsén, 2014; Tsagalidis, 2009). Detta gör handledarna särskilt viktiga när de kanske är de enda som ger eleverna aktuell yrkesförankring. Alla elever på BF läser exempelvis en kurs i kommunikation men kunskap om hur denna kommunikation går till inom det specifika yrket kan handledarna bidra med.

Man kan rikta kritik mot Lave och Wengers (1991) sätt att framhålla praktikgemenskapen som en idealvärld för lärande. I dagens samhälle med snabba teknikförändringar där mycket vetenskap ligger bakom arbetet, bland annat på förskolor, finns en begränsning med arbetsplatslärande som bland andra Fuller och Unwin (2004) uppmärksammat och som jag menar denna studie också visar. Arbetsplatsen kan vara ett bra ställe att lära ett yrke men ett kompletterande utbildningsstöd behövs i någon form.

En annan fråga är om det handledande förhållningssättet, som går ut på att hjälpa de som ska utbilda sig i yrket att förstå grunderna för yrket, är ett sätt som yrkeslärarna använder sig av vid undervisning i skolmiljö (Lauvås \& Handal, 2001). Med ett handledande förhållningssätt i klassrummet där eleverna får prova sig fram i yrket, får lagom svåra 
uppgifter och det ges möjlighet att diskutera vad som skedde med en mer erfaren person skulle därmed kunna leda till en liknande kunskapstillväxt för gymnasieskolans yrkeslärare.

\section{Implikationer för gymnasieutbildningen samt förskolan som praktikgemenskap}

Syftet med denna studie har varit att förstå den handledning och det yrkesutbildning som förekommer på förskolan. I studien har frågor som vilka motiv som ligger bakom handledarnas engagemang, vad de anser att eleverna borde lära sig och vad de tror att de lär samt hur handledningen går till lyfts fram. Avslutningsvis ställs här frågor om hur och vem som kan dra lärdom av det som har kommit fram i denna studie.

\section{Yrkeslärares relationer till arbetsplatsen}

Yrkesläraren är den som till sist står som ansvarig för helheten i elevernas skolgång även om läraren är osynlig i denna studie. Ett sätt för yrkesläraren på Barn- och fritidsprogrammet att dra lärdom av det som framkommit här skulle vara att se och ta vara på att BF har många duktiga handledare att tillgå. Handledning på förskolor har traditionellt bedrivits enligt handling och reflektionsmodellen (Lauvås \& Handal, 2001) och gör så fortfarande i stor utsträckning. Som beskrivits är inte alla handledare medvetna om att de utför en stor det av sitt arbete medan verksamheten pågår, det som här benämns handledning "i farten". Om lärarna vid kontakt med handledare synliggör hur handledning kan gå till så att handledarna kan fundera över hur de själva bedriver handledning skulle det kunna öppna upp för en tydligare handledningsprocess. Detta skulle kunna gagna både eleven, handledaren och därigenom praktikgemenskapen.

Finns det något att lära av studien för den som är yrkeslärare på ett annat program på gymnasieskolan? Inom ramen för denna studie har jag inte mött några andra handledare än de som arbetar på förskolan, därför är det bäst om var och en drar sina egna slutsatser i den frågan. Som Larsson (2009) skriver så är det läsaren själv som avgör om sammanhanget är nog likt för att kunna generalisera ur. Möjliga vägar att gå är att fundera kring hur handledning går till på de arbetsplatser som elever från ett visst program går till och vilken form av handledning som skulle passa bäst för det utbildningsområdet. En slutsats som dras här är att eleverna kommer påverka arbetsplatsen positivt då de genom sin närvaro får personalen att reflektera kring arbetet som de utför. Ännu en slutsats är att ett handledande förhållningssätt kan leda till utveckling och lärande även för yrkesläraren. 
Förhoppningsvis kan alla yrkeslärare finna stöd i hur handledning för yrkeslärande kan gå till och få källor för att lära mer om handledning i denna studie. Att som yrkeslärare uppmärksamma utbildningsanordnare på att handledare kan ha många olika tankar med varför de är handledare och vilka konsekvenser de kan ha för kvalitén på det arbetsplatsförlagda lärandet skulle kunna bidra till att yrkesläraren får mer tid till att möta handledare och elever ute på arbetsplatsen. Alla handledare har inte pedagogisk utbildning som handledarna i detta exempel och en av lärdomarna från länder med lång erfarenhet av lärlingsutbildning är att handledarna bör ha pedagogiska kvalitéer precis som de behöver vara duktiga yrkesmänniskor (Kirpal \& Tutschner, 2008).

\section{Förskolan som praktikgemenskap}

Vill en förskolechef ha en personalgrupp med medlemmar som reflekterar över sitt arbete och som därigenom kan bli medvetna om vad de gör och varför, då ska de se till att stå först i kön för att ta emot elever i sin verksamhet. Det finns kommuner som har särskilda förskolor som tar emot elever och studenter från både gymnasieskolor och högskola och det kan nog vara en fördel när det blir få förskolor och handledare som kan bli extra duktiga. Risken är att de goda effekter elever kan bidra med inte kommer mer än ett fåtal arbetsplatser tillgodo på detta sätt. Verksamheten på dessa "övningsskolor" kanske dessutom riskerar att bli så bra att de inte avspeglar hur det ser ut i den övriga verksamheten. Förskolan som praktikgemenskap kommer i så fall inte att dra nytta av alla de goda effekter en nykomling på arbetsplatsen kan innebära, och det praktikgemenskap eleverna kommer in i kanske inte motsvarar en mer normal förskola.

\section{Utbildningsanordnarnas ansvar för APL}

En tanke som har följt mig genom hela arbetet har varit hur man kan ge handledarna stöd $i$ att utföra sitt uppdrag så bra som möjligt. Är det en utopi att få alla handledare att gå en handledarutbildning? Vad ska en sådan i så fall innehålla? Sjuksköterskorna har handledaruppdraget inskriven i sin yrkesbeskrivning och Brammers (2006) forskning visar att det finns handledare som helst inte vill ha uppdraget men som tar det ändå. Av de handledare jag intervjuade utförde alla uppdraget på frivillig bas om än av olika anledningar. Av den anledningen ser jag ingen vinst med att skriva in uppdraget som obligatoriskt även för förskolans och barnomsorgens personal. Att däremot uppmärksamma att handledaren genom sitt uppdrag lär och utvecklas både personligt och att det tillför verksamheten positiv utveckling skulle kunna väcka större intresse och respekt för uppdraget. "Handledare" skulle kunna bli ett karriärsteg precis 
som "föreståndare" eller "arbetslagsledare" där det kan krävas speciella kvalifikationer.

Att tala om för handledarna hur de ska utföra sitt uppdrag till punkt och pricka tror jag heller inte på. Men, än en gång, att se till att alla handledare får redskap för att förstå och utföra sitt uppdrag så bra de bara kan anser jag däremot vara huvudmannens skyldighet. Hur handledarna ska få tillgång till dessa redskap tror jag är en diskussion och uppgift för Skolverket och utbildningsanordnare på både universitets och gymnasienivå att arbeta tillsammans kring. Yrkeslärarna har här en nyckelposition och genom sina kontaktytor kan de fungera som bärare av handledningskunskap mellan universitet, gymnasieskola och arbetsplats.

\section{Förslag på fortsatt forskning}

Denna studie har väckt många tankar hos mig. Genom valet av metod har jag endast kunnat uttala mig om det som har framkommit vid intervjuer vilket kan ses som en begränsning i studien. Att på plats följa handledare och observera hur handledning genomförs vore intressant. Detta skulle kunna ge djupare kunskap kring relationen mellan handledare och elev samt en ökad förståelse för hur handledning görs på förskolan. Ett annat sätt att komplettera denna studie vore att se hur handledning går till inom andra sektorer för andra program på gymnasieskolan. Hur bedriver och tänker VVS-installatören, lantbrukaren eller frisören om handledning?

Komplexiteten i styrdokumenten för gymnasieskolan har lämnats därhän i denna studie men spelar stor roll till exempel när elever ska bedömas på arbetsplatsen. När nu yrkesutbildning i större utsträckning ska ske på arbetsplatsen vore det intressant att tillsammans med handledare och yrkeslärare utforma forskningsprojekt för att överbrygga avståndet dem emellan. Att tillsammans utarbeta sätt att konkretisera svåra begrepp i läroplanen så väl som i yrket skulle kunna bidra till att arbetsplatsen och yrkesutbildningen kom närmare varandra.

I denna studie föll valet på att bortse från handledarnas utbildningsbakgrund. Ett sätt att komplettera denna studie skulle därför kunna vara att titta närmare på vilka olikheter i arbetsuppgifter och sätt att handleda förskollärare och barnskötare uppvisar.

Att det dessutom finns för lite forskning om yrkeslärande på skola håller jag med Berner (2010) om. I fallet barnskötarutbildningen på Barn- och fritidsprogrammet vore en intressant ingång att studera hur denna utbildning tar form i klassrummet för att därigenom kunna utveckla yrkesdidaktiken även där. Även om pendeln svänger emot en yrkesutbildning allt mer förlagd på arbetsplatsen kommer nog gymnasieskolan i fysisk form finnas kvar. 


\section{Referenser}

Ambjörnsson, F. (2004) I en klass för sig. Genus, klass och sexualitet bland gymnasietjejer. Stockholm: Ordfront

Benner, P. (1993) Från novis till expert - mästerskap och talang $i$ omvårdnadsarbetet. Lund: Studentlitteratur

Berner, B. (2010) Crossing boundaries and maintaining differences between school and industry: forms of boundarywork in Swedish vocational education. Journal of Education and Work, 23:1, 27-42

Billet, S. (2003) Workplace mentors: demand and benefits. Journal of Workplace Learning, 15:3, 105-113

Boyatzis, R. E. (1998) Transforming qualitative information: thematic analysis and code development. Thousand Oaks, CA: Sage

Brammer, J. (2006) A phenomenographic study of registered nurses' understanding of their role in student learning - An Australian perspective. International Journal of Nursing studies, 43:8, 963-973

Braun, V. \& Clarke, C. (2006) Using thematic analysis in psychology. Qualitative Research in Psychology 3:2, 77101

Bryman, A. (2001) Samhällsvetenskapliga metoder. Malmö: Liber

Caplan, G. (1970) The Theory and Practice of Mental Health Consultation. New York: Basic Books

Contu, A. \& Willmott, H. (2003) Re-Embedding Situatedness: The Importance of Power Relations in Learning Theory. Organization Science 14:3, 283 - 296

Dahlgren, L. - O. (1990) Undervisningen och det meningsfulla lärandet. Skapande vetande Rapport 1990:16 Linköping: Linköpings universitet

Denzin, N. (2001) The reflexive interview and a performative social science. Qualitative research 1:1, 23-46

Dir. 2007:8 En reformerad gymnasieskola Utbildningsdepartementet

Ekström, K. (2007) Förskolans pedagogiska praktik - ett verksamhetsperspektiv. Doktorsavhandling Umeå Universitet

Ellström, P.-E. \& Hultman, G. (red.) (2004) Lärande och förändring i organisationer. Lund: Studentlitteratur 
Ellström, P.-E. (1992) Kompetens, utbildning och lärande $i$ arbetslivet Problem begrepp och teoretiska perspektiv. Stockholm: Nordstedts Juridik $A B$

Eriksson, K. (2007) Att byta perspektiv: från doktorand till forskarhandledare. I: Pedagogiska utmaningar i tiden: 10:e universitetspedagogiska konferensen vid Linköpings universitet 8-9 november 2006. -2007. - (CUL-rapporter, 1650 - 8173;12), 97 - 103

Europaparlamentets och rådets rekommendation av den 18 december 2006 om nyckelkompetenser för livslångt lärande (2006) http://eur-lex.europa.eu/legalcontent/SV/ALL/;jsessionid=2dQ0TsfGD1JGV4vLtc9Gw82p KpD36kVMLrfHBTrLSKkvQJQJKPnJ!488601054?uri=CELEX:32006H0962 hämtad 2014-05-09

Fejes, A. \& Köpsén, S. (2014) Vocational teachers' identity formation through boundary crossing. Journal of Education and Work, 27:3. 265-283

Franke, A. (1990) Handledning i praktiken En studie av handledares och lärarkandidaters uppfattningar av handledning i lärarutbildningens praktikdel.

Doktorsavhandling Linköping Studies in Education, Dissertations No. 30

Folke-Fichtelius, M. (2008) Förskolans formande: statlig reglering 1944-2008. Doktorsavhandling Uppsala universitet

Fock, M. (2008) Den lärarinna är den lyckligaste Händelser $i$ förskollärarnas historia. Solna: Lärarförbundets förlag

Fuller, A. $\mathrm{m} \mathrm{fl}$ (2005) Learning as peripheral participation in communities of practice: a reassessment of key concepts in workplace learning. Brittish Education Research Journal 31:1, 49-68

Fuller, A. \& Unwin, L. (2004) Expansive Environments: Integrating Organisational and Personal Development. In: H. Rainbird, A. Fuller \& A. Munro (red.) Workplace Learning in Context. London: Routledge

Gamble, J. (2010) Modeling the Invisible: The pedagogy of craft apprenticeship. Studies in Continuing Education, 23:2, 185200

Groenwald, T. $\mathrm{m} \mathrm{fl}$ (2011) Towards a Definition and Models of Practice for Cooperative and Work-Integrated Education. In: Coll, R. K. \& Zegwaard, K E (red.) International Handbook for Cooperative and Work-Integrated. Education Lowell: World Association for Cooperative Education, Inc. 
Hammar Chiriac, E. (2010) Basgruppshandledning inom PBL på högskola och universitet. I: Grupphandledning: forskning och erfarenhet från olika verksamhetsområden. 109-127

Hammarström-Lewenhagen, B. (2006) Följ mig bortåt vägen... Om pedagogisk handledning i förskolan. Stockholm HLS förlag

Hiller, H. \& DiLuzio, L. (2004) The Interviewee and the Research Interview: Analyzing a Neglected Dimension in Research Canadian Review of Sociology \& Anthropology 41:1

Hodkinson, P., Biesta, G. \& James, D. (2008) Understanding Learning Culturally: Overcoming the Dualism Between Social and Individual Views of Learning. Vocations and Learning 2008:1, 27-47

Hodkinson, P. (2005) Reconceptualising the relations between college-based and workplace learning. Journal of Workplace Learning 17:8, 521-532

Hultman, G., Schoulz, J. \& Stolpe, K. (2011) Samspelet lärarstuderande - handledare Den verksamhetsförlagda utbildningen. Pedagogisk Forskning i Sverige 16:2, 118-137

Huzzard, T. (2004) Communities of domination?

Reconceptualising organisational learning and power. Journal of Workplace Learning 16: 6, 350-361

Höghielm, R. (2005) Yrkesbaserat lärande Erfarenheter från PEOPLE delprojekt i Söderhamn 2002 till 2005. Ljusdal: ab romi tryck

Jernström, E. (2000) Lärande under samma hatt: En lärandeteori genererad ur multimetodiska studier av mästare, gesäller och lärlingar. Doktorsavhandling Luleå tekniska universitet

Kirpal, S. \& Tutschner, R. (2008) Eurotrainer Making Lifelong learning possible Vol.1 http://ec.europa.eu/education/moreinformation/doc/eurotrainer1 en.pdf hämtad 2013-10-05

Kvale, S. \& Nielsen, K (2000) Mästarlära Lärandet som social praxis. Lund: Studentlitteratur

Kvale, S. \& Brikmann, S. (2009) Den kvalitativa forskningsintervjun. Lund: Studentlitteratur

Lapadat, J. \& Lindsay, A. (1999) Transcription in research and practice: from standardization of technique to interpretive positioning. Qualitative Inquiry 5, 64-86

Larsson, S. (2005) Om kvalité i kvalitativa studier. Nordisk Pedagogik 25: 1, 16-35 
Larsson, S. (2009) A Pluralist view of generalization in qualitative research. International Journal of Research \& Method in Education 32:1, 25-38

Lauvås, P. \& Handal, G. (2001) Handledning och praktisk yrkesteori. Lund: Studentlitteratur

Lave, J. \& Wenger, E. (1991) Situated learning. Legitimate peripheral participation New York: Cambridge University Press

Lemar, S. (2001) Kaoskompetens och gummibandspedagogik: en studie av karaktärsämneslärare i en decentraliserad gymnasieorganisation. Doktorsavhandling Umeå universitet, Pedagogiska institutionen

Linden, J. (1998) Handledning av doktorander. Falun: Nya Doxa Lundgren, M. \& von Schantz Lundgren, I. (2012) Synliggörande av tyst kunskap i gymnasial yrkesutbildning Nordic Journal of Vocational Education and Training 2:1, 1-12

Lundström, U. (2007) Gymnasielärare - perspektiv på lärares arbete och yrkesutveckling. Doktorsavhandling Umeå universitet

MacDougall, C. \& Fudge, E. (2001) Pearls, Pith and Provocation. Planning and Recruiting the Sample for Focus Groups and In-Depth Interviews. Qualitative Health Research, 11:1, 117126

Magnusson, P. (2002) Essä över kunskapsutvecklings processen som forskarhandledare: en reflektion om handledning av doktorander. I: Universitetspedagogiska konferensen (6: 2002: Linköping): Bredd och djup. 2002 (CUL-rapporter, 1650 - 8173;4), 102 - 111

Molander, B. (1996) Kunskap i handling. Göteborg: Daidalos AB.

Nielsen,K. \& Kvale, S. (2000) Mästarlära som lärandeform av idag. I: Nielsen, K. \& Kvale, S (red) Mästarlära Lärandet som socialpraxis. 27- 46 Lund: Studentlitteratur

Nilsson, L. (1981) Yrkesutbildning i nutidshistoriskt perspektiv Doktorsavhandling ACTA Universitatis Gothoburgensis.

Näf, G.-B. (1999) Handledning - betydelse och definitioner. Vård $i$ Norden 19: 1, 26 - 31

Ohlsson, J. (1996) Kollektivt lärande Lärande i arbetsgrupper inom barnomsorgen. Doktorsavhandling Stockholms universitet, Pedagogiska institutionen

Petersson, B. \& Vahlne, L. (1997) Handledning: - ett vårdpedagogiskt verktyg. Lund: Studentlitteratur 
Roulston, K. (2001) Data analysis and 'theorizing as ideology`.

Qualitative Research, 1, 279-302

Salminen-Karlsson, M. (2006) Situating gender in situated

learning. Scandinavian Journal of Management 22, 31-48

SCB (2013) Utbildningsstatistik årsbok 2013

SCB (2012) På tal om kvinnor och män. Lathund om jämställdhet 2012. Örebro: SCB-Tryck

Schön, D. (1983/1995) The Refective Practitioner. Toward a new design for teaching and learning in the profession. San

Francisco: Jossey-Bass

SFS 1985:1985:1100 Skollagen Utbildningsdepartementet hämtad 2012-03-19

SFS 2010:2039 Gymnasieförordningen Utbildningsdepartementet http://62.95.69.3/SFSdoc/10/102039.PDF hämtad 2012-03-19

SFS 2010:800 Skollag Utbildningsdepartementet

http://www.riksdagen.se/sv/Dokument-

Lagar/Lagar/Svenskforfattningssamling/Skollag-

2010800 sfs-2010-800/?bet=2010:800 hämtad 2012-03-19

Skolinspektionen (2011) Arbetsplatsförlagd utbildning i praktiken en kvalitets granskning av gymnasieskolans

yrkesförberedande utbildningar. Kvalitetsgranskning

Rapport 2011:2

Skolverket (1997) Fem gymnasieprogram under

omvandlingstryck. Skolverkets rapport nr 149, Stockholm:

Liber

Skolverket (2000) Reformeringen av gymnasieskolan - en

sammanfattande analys Skolverkets rapport nr 187

http://www.skolverket.se/polopoly fs/1.1099!/Menu/article

lattachment/00-554.pdf hämtad 2013-10-24

Skolverket (1998/2010) Läroplan för förskolan Lpfö 98/10

http://www.skolverket.se/om-skolverket/visa-enskildpublikation? xurl =httpprocent3Aprocent2Fprocent2Fww w5.skolverket.seprocent2Fwtpubprocent2Fwsprocent2Fsk olbokprocent2Fwpubextprocent2Ftrycksakprocent2FRecor dprocent3Fkprocent3D2442 hämtad 2013-01-10

Skolverket (2011) Läroplan, examensmål och

gymnasiegemensamma ämnen för gymnasieskolan 2011.

Stockholm: Fritzes 
Skolverket (2012) Fakta om Barn- och fritidsprogrammet

http://www.skolverket.se/forskola-och-

skola/gymnasieutbildning/program/nationella-

program/barn-och-fritidsprogrammet/fakta-om-barn-och-

fritidsprogrammet-1.117051 hämtat 2012-04-16

Skolverket (2013) Statistik \& Utvärdering

http://www.jmftal.artisan.se/databas.aspx?presel\#tab-1

hämtad 2014-01-20

Skolverket (2014a) Kursplan för Pedagogiskt arbete

http://www.skolverket.se/laroplaner-amnen-och-

kurser/gymnasieutbildning/gymnasieskola/sok-amnen-

kurser-och-

program/subject.htm?subjectCode=PEG\&courseCode=PE

GPEA0\&lang=sv\&tos=gy\#anchor PEGPEA0 hämtad 2014-

01-17

Skolverket (2014b) Statistikdatabas

http://siris.skolverket.se/reports/rwservlet?cmdkey=com

mon\&notgeo $=\&$ report $=$ gyelever Igy11\&p ar=2013\&p la

$\underline{n}$ kod=\&p kommunkod=\&p skolkod=\&p inriktning $=1$

hämtad 2014-03-24

Socialstyrelsen 2005 Kompetensbeskrivning för legitimerad

sjuksköterska

http://www.socialstyrelsen.se/Lists/Artikelkatalog/Attach ments/9879/2005-105-1 20051052.pdf hämtad 2012-02-20

SOU 2008:27 Framtidsvägen - en reformerad gymnasieskola.

Betänkande av Gymnasieutredningen

SOU 2011:72 Gymnasial lärlingsutbildning - med fokus på

kvalitet! Hur stärker vi kvaliteten i gymnasial

lärlingsutbildning? Slutbetänkande nationella

lärlingskommittén

Stenhouse, L. (1983) The Relevance of Practice to Theory. In:

Theory into Practice. Taylor \& Francis, Ltd. 22:3, 211-215,

Sundli, K. \& Söndenå, K. (2007) Reflektion och handledning i

lärarutbildningens praktik. I: Brusling, C. \& Strömqvist, G

(red.) Reflektion och praktik i läraryrket. 167-196 Lund:

Studentlitteratur

Säljö, R. (2000) Lärande i praktiken Ett sociokulturellt perspektiv.

Stockholm: Prisma 
Tallberg Broman, I. (1991) När arbetet var lönen: en kvinnohistorisk studie av barnträdgårdsledarinnan som folkuppfostrare. Doktorsavhandling Lunds universitet

Tallberg Broman, I. (1995) Perspektiv på förskolans historia. Lund: Studentlitteratur

Tanggaard, L. (2007) Learning at trade vocational school and learning at work: boundary crossing in apprentices' everyday life. Journal of Education and work 20:5, 453-466

Thunborg, C. (1999) Lärande av yrkesidentiteter: en studie av läkare, sjuksköterskor och undersköterskor. Doktorsavhandling Linköpings universitet

Tzagalidis, H. (2005) Därför fick jag bara Godkänt... : Bedömning i karaktärsämnen på HR-programmet. Doktorsavhandling Stockholms universitet

Wenger, E. (1998) Communities of Practice Learning, Meaning, and Identity. New York: Cambridge University

Vetenskapsrådet (2002) Forskningsetiska principer inom humanistisk-samhällsvetenskaplig forskning. http://www.codex.vr.se/texts/HSFR.pdf Hämtad 2012-0401

Åberg, K. (2009) Anledning till handledning Skolledares perspektiv på grupphandledning. Doktorsavhandling Högskolan i Jönköping

Örling, K. (2004) Lärande i vårdens vardag. I: Jernström, E. \& Säljö, R (red.) Lärande $i$ arbetsliv och var dag. Jönköping: Brain books 


\section{Intervjuguide}

Syfte med denna studie är att synliggöra handledarnas roll $\mathrm{i}$ det arbetsplatsförlagt lärande. Detta eftersom en viktig del av yrkesutbildning sker på arbetsplatsen.

Hur ser handledarna på sin roll som handledare för elever från gymnasieskolans BF-program? Vad vill de föra vidare i yrket?

Hur stämmer detta överens med läroplanens mål?

Vad har skolan för betydelse i det arbetsplatsförlagda lärandet?

\section{Intro}

Syftet med min intervju är att ta reda på hur handledare kan tänka om sitt uppdrag.

Jag kommer att intervjua personal på förskolor som fungerar som handledare för elever på Barn- och fritidsprogrammet. Skriva ut intervjuerna för att analysera dem. Bara jag kommer att veta vilka jag har intervjuat, i vilka kommuner och på vilka förskolor. Om, i citat kommer jag att göra det anonymt och ge dig ett annat namn. Du kan när som helst säga att du inte vill vara med längre och vi kan avbryta intervjun när som helst.

$45-60 \min$. 


\section{Handledarbakgrund}

1. Varför är du handledare? Hur kommer det sig att du fortsatt? Hur många år? Hur många gånger? Hur ofta de senaste åren? Har du gått någon handledarutbildning? Flera gånger?

\section{Handledning}

2. Beskriv en dag som handledare? Jmf dag utan elev?

3. Vad gör du som handledare? Hur sker handledning i det dagliga arbetet? Hur brukar du lägga upp det? Lika för alla elever? Olika, vad beror det på? Hur olika? Ålder/årskurs/intresse/erfarenhet/

4. Sitter ni ner två och två? När? Hur ofta? Vad gör ni då? Vad tar du upp?

5. Hur ser du på din roll som handledare? Vad spelar du för roll för eleven?

6. Kan du beskriva något tillfälle då du kände att handledning fungerade bra? Bra elev?

Varför var det ett bra tillfälle? Vad var det som gjorde att det blev bra handledning då?

7. Kan du beskriva något tillfälle som fungerade mindre bra?

8. Vad vill du att eleverna ska göra/få vara med om/uppleva under praktiken? Berätta hur du gör för att eleverna ska få vara med om det? Är det något som ni pratar om i arbetslaget? Hur fungerar det? Följer ni upp det? Hur?

9. Vad tycker du att eleverna faktiskt lär sig av att vara på praktik? Vad är det viktigt att de lär sig?

10. Finns det sådant som eleverna behöver lära för yrket och som är extra svår att prata om? Vad? Varför svår att prata om?

11. Brukar ni i arbetslaget prata om elevernas utveckling/ lärande/ handledning? Vad pratar ni om då? När?

12. Vad tycker du att praktiken fyller för syfte för eleverna?

\section{Gymnasieskolan}

1. Tycker du att eleverna behöver ha någon speciell kunskap innan de kommer ut på praktik? Vad behöver de ha med sig? Kunskap/intresse? Har de det? Vad är bra att lära i skolan? Vad fungerar bättre att lära på arbetsplatsen? Olika beroende på var i utbildningen? 
2. Berätta, hur går till när ni ska få en elev från gymnasieskolan. Hur bestäms det vems som ska vara handledare? Hur är arbetslaget involverade?

3. Hur ser kontakten med gymnasieskolan ut? Vilken kontakt har du med skolan där eleven går? Hur ofta? På vems initiativ sker kontakten?

4. Har eleverna med sig uppgifter/mål/krav från skolan? Hur tänker du om dem? Hur följer du/ni upp mål/krav som kommer från skolan?

\section{Avslutande frågor}

1. Har du något mer som du vill berätta om att vara handledare för gymnasieelever?

2. Hur länge har du varit verksam i förskola? Vilken utbildning har du? Yrkeserfarenhet?

Förskolan, kommunal/privat?

3. Ålder.

4. Om jag behöver komplettera frågorna är det ok om jag kontaktar dig igen? E-post adress? 